\title{
Characteristics of Beta Detection and Dose Measurement at Department of Energy Facilities
}

J. M. Mulvehill

L. W. Brackenbush

K. L. Swinth, PNL Project Manager

E. J. Vallario, DOE Project Manager

February 1987

Prepared for the U.S. Department of Energy

Office of Assistant Secretary for

Environment, Safety, and Health

under Contract DE-AC06-76RLO 1830

Pacific Northwest Laboratory

Operated for the U.S. Department of Energy

by Battelle Memorial Institute 


\section{DISCLAIMER}

This report was prepared as an account of work sponsored by an agency of the United States Government. Neither the United States Government nor any agency thereof, nor Battelle Memorial Institute, nor any of their employees, makes any warranty, expressed or implied, or assumes any legal liability or responsibility for the accuracy, completeness, or usefulness of any information, apparatus, product, or process disclosed, or represents that its use would not infringe privately owned rights. Reference herein to any specific commercial product, process, or service by trade name, trademark, manufacturer, or otherwise, does not necessarily constitute or imply its endorsement, recommendation, or favoring by the United States Government of any agency thereof, or Battelle Memorial Institute. The views and opinions of authors expressed herein do not necessarly state or reflect those of the United States Government or any agency thereof, or Battelle Memorial Institute.

\section{PACIFIC NORTHWEST LABORATORY operated by \\ BATTELLE MEMORIAL INSTITUTE for the UNITED STATES DEPARTMENT OF ENERGY under Contract DE-AC06-76RLO 1830}

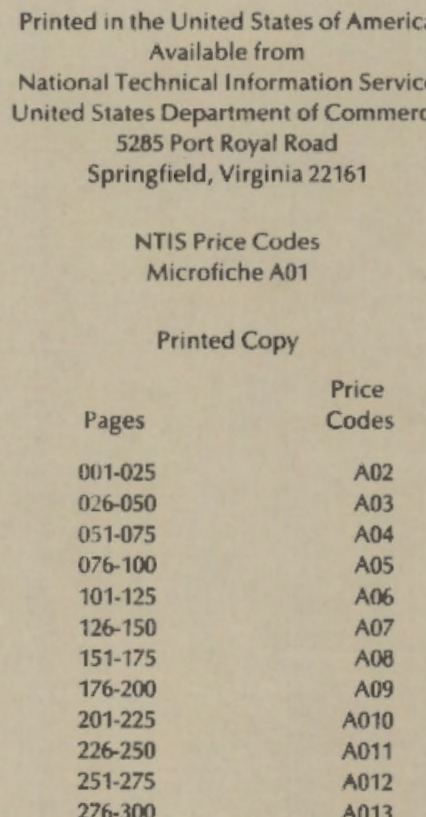


CHARACTERISTICS OF BETA DETECTION AND DOSE MEASUREMENT AT OEPARTMENT OF ENERGY FACILITIES

J. M. Mulvehill

L. W. Brackenbush

K. L. Swinth, PNL Project Manager

E. J. Vallario, DOE Project Manager

February 1987

Prepared for the Office of Assistant Secretary for Environment, Safety, and Health U.S. Department of Energy under Contract DE-AC06-76RLO 1830

Pacific Northwest Laboratory

Richland, washington 99352 
.

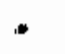

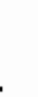

1

$\bullet$ 


\section{FOREWORD}

This report considers the current state of the art of beta dosimetry practices and beta detection methods used by heaTth physicists at U.S. Department of Energy (DOE) facilities. This information as well as that contained in a companion document, "Extremity Dosimetry at U.S. Department of Energy Facilities" (Harty et al. 1986), are based on a survey of DOE facilities.

Beta measurements are technicaliy difficult and innovative efforts must be expended to improve their accuracy. Perhaps the most pronounced problem is that beta dosimetry and instrumentation in use are highly energy and angular dependent. Many believe that beta exposures are adequately controlled because beta to photon ratios are assumed to be low. This assumption is not always valid as demonstrated by the accident at Three Mile Island (TMI). Significant beta doses exist where personnel are exposed to mixed fission products; for example, chemical reprocessing plants, reactor accidents, or where uranium metals are processed.

This report is part of an effort to increase the DOE response to this technically difficult area of health protection. Problem areas are addressed and methods recomended to improve beta dosimetry through a cooperative effort among the various DOE contractors. Your comments and suggestions are wel comed.

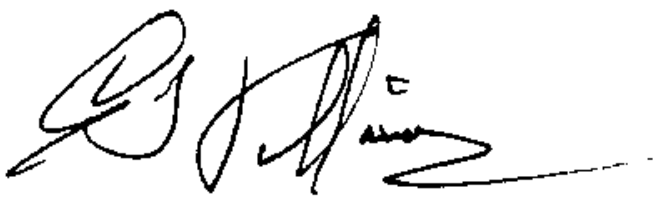

E. J. Vallario Acting Director Radiological Controls Division Office of Nuclear Safety U.S. Department of Energy 


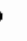




\section{EXECUTIVE SUMMARY}

The Department of Energy (DOE), Office of Nuclear Safety has established the Beta Measurements Evaluation and Upgrade Program to resolve problems associated with beta measurement and dosimetry (Swinth 1985). As part of this program, a survey was conducted to characterize existing beta measurement programs and extremity dosimetry programs at DOE facilities. This report describes the data obtained in the survey and presents reconmendations for necessary improvements in DOE programs. Background information on beta dosimetry is presented as a basis for understanding the information obtained in the survey.

\section{BACKGROUND INFORMATION}

The background information presented includes a summary of regulations for beta monitoring and dosimetry, recommendations from advisory groups, a brief discussion of beta radiations, and methods used for beta measurement and dosimetry.

Beta particles are nonpenetrating radiations and primarily contribute dose to the skin and eyes. Garmma doses are usually considered to be limiting because the regulated dose equivalent limits for the skin are three times larger than for the whole body. As a result, most dosimetry efforts in the past concentrated on the accurate measurement of gamma dose; beta dosimetry was a lesser concern.

Many of the current problems in beta dosimetry often originate because most beta dosimeters are modifications of gamma dosimeters. In addition, the dosimetry materials necessary for accurate measurement of beta dose were not available when most current systems were implemented; some regulations and recommendations have changed since the current systems were implemented.

Most existing dosimeters and instruments do not actually measure the dose averaged at a depth of 5 to $10 \mathrm{mg} / \mathrm{cm}^{2}$ in tissue, as required by current recommendations for the determination of shallow dose equivalent. As a result, calibration or correction factors are applied to obtain the correct shallow 
dose equivalent or "skin" dose. In many typical work locations these correction factors often vary by as much as an order of magnitude. Also, the beta energy spectra used for calibration may not be representative of the spectra found in the workplace. The uncertainty in applying the appropriate correction/calibration factor is the main problem of current beta dosimetry.

\section{SURVEY FINDINGS}

The survey revealed that DOE facilities use a wide variety of survey instruments, personnel dosimeters, and calibration procedures to assess external beta dose. Therefore, accuracy in beta measurements varies among DOE facilities. The exact assessment methodology at a particular site appears to be a resilt of the experience and preference of the radiation protection staff at that site.

Significant findings of the survey include:

- The programs for calibration, performance testing, and quality assurance are not always adequate for both personnel dosimetry and instrumentation.

- In many instances, instruments and dosimeters are not appropriately designed or used for proper beta dosimetry. Many of the probiems are the result of the modification of devices originally designed for gamma dosimetry and the lack of commercially available devices.

- Calibration sources generally are not traceable to the National Bureau of Standards (NBS) and often have energies significantly different from the average energy of beta radiations measured in the field.

- Nonpenetrating dose (or shallow dose equivaient) is not uniformly measured or reported among DOE facilities.

- In many instances, beta radiation field geometries are not properiy determined in the work Tocations; this improper determination leads to errors in applying necessary correction factors. 
RECOMMENDATIONS

The authors recommend the following actions:

- The DOE Beta Measurement Evaluation and Upgrade Program should promote a cooperative effort among DOE facilities to improve beta dosimetry practices.

- Improved beta instruments and dosimeters must be developed to permit the upgrade of beta detection and measurement; this technology should be made available commercially to allow widespread use of the improvements.

- A program to accurately characterize the performance of beta dosimeters and instruments currently in use must be implemented; this could be done in conjunction with DOE Laboratory Accreditation Program (DOELAP).

- A manual of good practices for beta dosimetry and measurement with emphasis on calibration, field measurement techniques, and quality assurance practices, should be prepared to standardize measurement methodology at DOE sites.

- A series of beta workshops for DOE contracter personne? should be initiated to promote discussion of beta dosimetry and measurement problems and solutions.

- Standards for the depths and areas for which beta doses and measurements are made or averaged should be developed. Additional guidance is particulary important for beta measurements on extremities. Much of the necessary information will be forthcoming from NCRP Committee 80 .

- A uniform reporting system should be established for recording beta doses for individual radiation protection records.

- Supplemental investigations that amplify and correct specific problem areas identified in this study should be initiated to better quantify the magnitude of beta measurement error at DOE sites. 
•

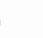

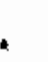




\section{ACKNOWLEDGMENTS}

The authors would like to acknowledge the efforts of the health physicists at the various DOE sites who responded to this survey. Their comments and thorough responses to the questionnaire will serve to improve beta programs at a! $\mathrm{DOE}$ facilities.

The efforts of J. K. Rhodes in data processing and M. A. Eierdam and M. Cross in report assembly are also appreciated. Advice from R. Harty and editorial comments from $A$. Marshall and C. Brim are gratefully acknowledged. 
.

. 
CONTENTS

FOREWORD

EXECUTIVE SUMMARY

ACKNOWLEDGMENTS

1.0 INTRODUCTION

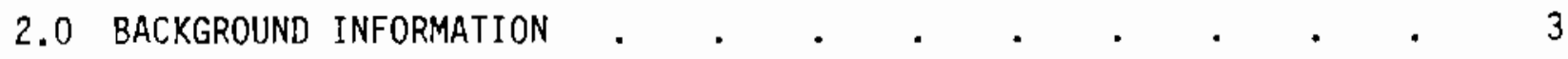

2.1 PRINCIPLES OF BETA RADIATION • .

2.2 CURRENT REgULATIONS AND RECOMMENDATIONS . . . . . . . 4

2.3 BETA DOSIMETRY . . . . . . . . . . . . . . . . . 4

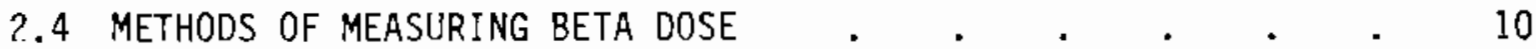

2.4.1 Personnel Dosimeters . . . . . . . . . 10

2.4.2 Portable Survey Instruments . . . . . . 17

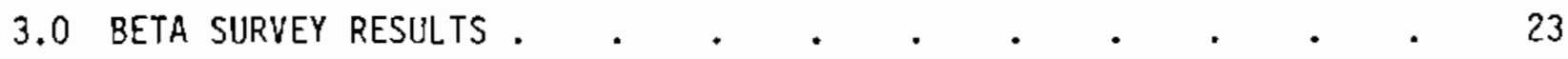

3.1 GENERAL CHARACTERISTICS OF BETA MEASUREMENTS PROGRAMS . . 25

3.2 PERSONNEL DOSIMETERS FOR BETA ASSESSMENT $\quad$ • $\quad . \quad$. $\quad$. 25

3.2.1 Thermoluminescent Dosimeters . . . . . 78

3.2.2 Photographic Film Dosimeters . . . . . 30

3.2.3 Quality Assurance . . . . . . . . . 30

3.3 RADIATION DETECTION AND MEASUREMENT INSTRUMENTS • • . • 31

3.3.1 Instrument Calibration Procedures . . . . . $\quad 32$

3.3.2 Instrument Performance Testing . . . . . . 35

3.4 TELEPHONE SURVEY . . . . . . . . . . . . . . . . . . 38

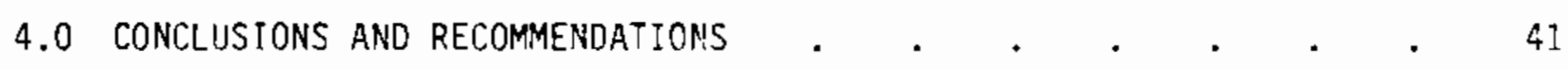

4.1 CURRENT PROBLEMS OF BETA DOSIMETRY . . . . . . . . . . 41

4.1 .1 Personnel Dosimeters . . . . . . . . . . 41

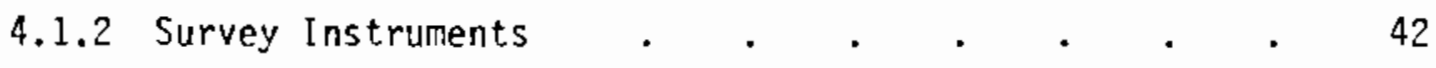


4.1.3 Correction Factors and Calibration Factors . . . 43

4.1 .4 Conclusions. . . . . . . . . . . . 44

4.2 RECOMMENDATIONS TO IMPROVE BETA DOSIMETRY . . . . . 46

REFERENCES . . • . . . . . . . . . . . . . 49

APPENDIX A - BETA MEASUREMENT QUESTIONNAIRE AND RESPONSES . • . A. A.1

APPENDIX 8 - PORTABLE, LABORATORY, AND PERSONNEL CONTAMINATION

INSTRUMENTS ROUTINELY USED TO DETECT AND/OR

MEASURE BETA ACTIVITY AT DOE FACILITIES • . $\quad$ • $\quad$. 8.1 


\section{FIGURES}

1 Predominant Beta-Emitting Nuclides Found at DOE Facilities . . 26

2 Beta Instrument Calibration at DOE Facjlities . . . . . 33

\section{TABLES}

1 Measured Factor for How Much a LiF TLD Would Underestimate

the Actual Beta Dose Relative to the PTB ${ }^{90} \mathrm{Sr} /{ }^{90} \mathrm{Y}$ Dose . . . 13

2 Commercial Dosimeter Responses to Beta Calibration Sources . . 14

3 Response of Commercial Dosimeters to Beta Radiation at NRC-Licensed Facilities . . . . . . . . . . . . 15

4 Properties of the Ideal Beta Dosimeter . . . . . . . 16

5 Examples of Correction Factors Used When Measuring ${ }^{90} \mathrm{Sr} /{ }^{90} \mathrm{Y}$ Disk Sources with a "Cutie Pie" Ion Chamber

Survey Instrument $. \quad . \quad . \quad . \quad . \quad . \quad . \quad$. . . 19

6 Examples of Rectangular Volume Correction Factors for a "Juno" Survey Meter Exposed to ${ }^{90} \mathrm{Sr} /{ }^{90} \mathrm{Y}$ Disk Sources . . . $\quad 20$

7 Response of Commercial Survey Instruments to Beta Fields at NRC-Licensed Facilities . . . . . . . . . 20

8 DOE Facilities Included in Study . . . . . . . . . . . . $\quad$. 24

9 Characteristics of Beta-Emitting Radionuclides Found at
DOE Facilities.
.

10 Radiation Sources Used to Calibrate Personne? Dosimeters . . 28

11 Type of Formal Quality Control/Quality Assurance Program . . 31

12 Number of Facilities Using Various Sources for Initial or Secondary Calibration of Beta Measurement Instruments According to Source Type and Geometry . . . . . . . 34

13 Beta Radiation Sources for Instrument CaTibration . . . . . 34

14 Procedure or Source Used to Determine the True Beta Dose Rate of the Source Used for Instrument Calibration . . . 36

15 Specifications Followed for Instrument Performance Testing . . 36

16 Types of Periodic Checks Performed . . . . . . . . . . 37 
CHARACTERISTICS OF BETA DETECTION AND DOSE

MEASUREMENT AT DEPARTMENT OF ENERGY FACILITIES

\subsection{INTRODUCTION}

The measurement of beta dose has always been difficult. Little effort has been expended to improve the accuracy and precision of devices used for beta dose measurement. A significant reason for the lack of progress is that beta (nonpenetrating) doses have not been considered the limiting factor in radiation exposures. Generally, the permissible skin doses are three times the whole-body limit, and the ratio of nonpenetrating-to-penetrating radiation has not been high enough to make the nonpenetrating doses limiting. As knowledge of beta dose rates improves and stricter radiation control procedures that reduce doses from penetrating radiations are enacted, this rationale is found to be inadequate; more attention must be given to improving beta dose measurements.

In most cases, attempts have been made to adapt devices designed to measure other radiations (usualiy gamma radiation) to beta measurements. A large number of radiation workers are monitored in situations where their nonpenetrating (beta and low-energy photon) exposure may be significantiy underestimated because of the design or response of the dosimeters. In many instances, the dosimeters do not detect exposure to beta radiation. For example, attempts have been made to adapt "thick" TLDs for measuring gamma dose to beta measurement by using filters of various types and thicknesses. Nonconservative errors of a factor of 10 can easily occur using these TLDs for beta dosimetry measurements. Similarly, instruments such as large volume ion chambers may also lead to nonconservative errors of a factor of 10 in field measurements.

The Department of Energy (DOE) Office of Nuclear Safety has established the Beta Measurement Evaluation and Upgrade Program to resoive problems associated with beta measurement. As part of this program, a survey was conducted to characterize existing beta measurement programs at DOE facilities. The responses to the survey are described in this report. The responses provide an indication of the beta dosimetry practices and beta detection methods used 
by health physicists in DOE facilities. This report is closely associated with the report "Extremity Dosimetry at U.S. Department of Energy Facilities" (Harty et al. 1986).

This document is divided into three parts. The first part contains background information developed from operational experience and a review of the current literature. The background information is presented to provide a basis for understanding the results of the survey. The second part is an analysis of the results of the survey on current dosimetry practices at DOE facilities that handle beta emitters. The information contained in the background section as weli as the survey responses are used as a basis for recominendations for areas of further research and development to improve beta dosimetry. These recommendations are presented in the third part. 


\subsection{BACKGROUND INFORMATION}

A review of the regulatory and technical basis for beta dosimetry is presented as background information for understanding the survey results. This review includes the basic principles of beta radiation; a description of beta dosimetry; a summary of the DOE regulations and the recommendations of various advisory groups regarding beta dosimetry; and methods of measuring beta dose, including a description of the design, response, and calibration of beta dosimeters and portable survey instrumentation.

\subsection{PRINCIPLES OF BETA RADIATION}

The term "beta decay" refers to electron emissions that are a result of the nuciear decay process, which brings the neutron/proton ratio of a nucieus closer to stability. Neutron-rich nuclei generaliy emit negatively charged beta particles (sometimes referred to as negatrons), while neutron deficient nuclei generally emit positively charged beta particles (positrons) or decay via electron capture. Beta particles can emerge from this decay process with a broad spectrum of energies that are characteristic of each radionuclide. Some nuclides are pure beta emitters while others are accompanied by one or more gamma rays. The latter is always true of positron emitters since they result in the creation of two annihilation photons with energies of 0.51 i lie". Each beta spectrum has a distinctive asymmetric curve shape with energies ranging from zero to a fixed maximum energy. The average energy is roughly approximated as one-third of the maximum beta particle energy. This average beta-ray energy represents the energy per disintegration that may be absorbed by tissue during radiation interactions if intermediate absorbers are not present.

Beta emissions are commonly listed and referred to by their maximum possible energy ( $\left.E_{\max }\right)$. The maximum energy in beta decay processes can vary over a wide range of energies ( $E_{\max }=0.018 \mathrm{MeV}$ for tritium to $E_{\max }=3.53 \mathrm{MeV}$ for $\left.{ }^{106} \mathrm{Rh}\right)$. Most common $\mathrm{E}_{\text {max }}$ values range between 0.3 and $1.0 \mathrm{MeV}$. The distance a beta particle travels depends on surrounding absorber materials and deviations in the electron path caused by changes in electron direction. A useful rule of thunb for absorber materials with low atomic numbers is that the 
absorber thickness that stops about one-half of the beta particies is equal to approximately one-eighth of the particle range. The range of beta particles is often given in terms of the areal range, which is the linear range. (in $\mathrm{cm}$ ) multiplied by the material density (in $\mathrm{mg} / \mathrm{cm}^{3}$ ). The areal range (in $\mathrm{mg} / \mathrm{cm}^{2}$ ) is virtually independent of the atomic number for high atomic number materials.

Beta particles with energies less than $0.07 \mathrm{MeV}$ cannot penetrate the skin to the basal epidemal cell layer, assuming a skin thickness of approximately $7 \mathrm{mg} / \mathrm{cm}^{2}$. As examples of the penetrability of beta radiation, up to $80 \%$ of ${ }^{147} \mathrm{Pm}$ beta particles ( $\mathrm{E}_{\max }=0.24 \mathrm{MeV}$ ) are absorbed within $7 \mathrm{mg} / \mathrm{cm}^{2}$ of tissue; beta particles of ${ }^{204} \mathrm{Tl}$ ( $E_{\max }=0.76 \mathrm{MeV}$ ) do not perietrate beyond $300 \mathrm{mg} / \mathrm{cm}^{2} ;{ }^{90} \mathrm{Sr} /{ }^{90} \mathrm{Y}\left(\mathrm{E}_{\max }=2.28 \mathrm{MeV}\right)$ betas do not penetrate beynnd $1000 \mathrm{mg} / \mathrm{cm}^{2}$ and only $20 \%$ of ${ }^{90} \mathrm{Sr} /{ }^{90} Y$ betas penetrate beyond $300 \mathrm{mg} / \mathrm{cm}^{2}$.

\subsection{CURRENT REGULATIONS AND RECOMMENDATIONS}

The radiation protection standards and requirements for beta monitoring at DOE facilities are given in DOE Order 5480.11, Chapter XI, "Standards and Requirements for Radiation Protection (DDE 1981). The current DDE orders indicate that a beta exposure below a maximum energy of $700 \mathrm{keV}$ will not penetrate the lens of the eye; therefore, the applicabie dose-equivalent limit for these energies would be the same as the dose-equivalent limit for the skin. The unlimited areas of the skin (except the hands and forearms) are subject to $15 \mathrm{rem} / \mathrm{yr}(0.15 \mathrm{~Sv})$ or $5 \mathrm{rem} / \mathrm{calendar}$ quarter $(0.05 \mathrm{~Sv})$. The skin of the hands and forearms is subject to the same dose equivalent limits as the hands and forearms $[75 \mathrm{rem} / \mathrm{yr}$ (25 rem/ca]endar quarter) and $30 \mathrm{rem} / \mathrm{yr}$ (10 rem/ calendar quarter) respectively]. The order also requires that exposures shall be maintained as 10 as reasonably achievable (ALARA) within these guidelines. Personnel monitoring is required to meet. these limits where the potentia? exists for an individual to receive in excess of $10 \%$ of the quarteriy limit.

The requirements for beta monitoring as outiined in the DOE Order 5480.13 may be revised. A draft of the proposed DOE Order 5480.11, Chapter XI, "Standards and Requirements for Radiation Protection," has been writter based on the proposed Envirommental Protection Agency (EPA) guidance. The draft 
states that the dose equivalent received in any year by a radiation worker shall not exceed 50 rem (0.5 Sv) to the skin or extremity of the body.

The current DOE radiation protection standards and requirements state that the "methods of estimating dose commitment to the organ of interest should be ... consistent with assumptions and recommendations of the EPA, the National Council on Radiation Protection and Measurements (NCRP), and the International Commission on Radiological Protection (ICRP)" (DOE 1981). Before 1970, the Federal Radiation Council (FRC) was responsible for providing recommendations to the President in the form of Federal Radiation Protection Guidance for Occupational Exposure. During 1970, the administrator of the EPA was charged to "...advise the President with respect to radiation matters, directly or indirectly affecting health, including guidance for all federal agencies in the formulation of radiation standards and in the establishment and execution of programs of cooperation with states" (Executive Order 1083, the Atomic Energy Act (as amended) and Peorganization Plan No. 3 of 1970). The current Federal Radiation Protection Guidance is the same as that promulgated by the FRC in 1960. The recommendations of the FRC, NCRP, and ICRP provide the background for the DOE requirements and in some cases provide additiona? guidance.

The recommendations of the FRC were transmitted in the previous federa? guidance (25 FR 4402) approved by President Eisenhower on May 13, 1960 (FRC 1960). The FRC does not specifically recommend any beta dose limits; rather, it limits skin exposures to $30 \mathrm{rem} / \mathrm{yr}(0.30 \mathrm{~Sv})$ or $10 \mathrm{rem} /$ quarter $(0.10 \mathrm{~Sv})$.

The NCRP in Report 39 (1971) recommends as a guideline the same dose limits as in the current DOE order: a maximum permissible dose equivalent of $15 \mathrm{rem} / \mathrm{yr}(0.15 \mathrm{~Sv})$ to the skin [with less than $5 \mathrm{rem} /$ quarter $(0.05 \mathrm{~Sv})$ ]. The NCRP recommends that personnel monitoring shatl be performed for each cccupationally exposed individual for whom there is a reasonable possibility of receiving a dose exceeding $1 / 4$ of the applicable maximum permissible dose equivalent. The report also states: 
"The significant area for skin irradiations can reasonably vary with the nature of the exposure. External radiation of low penetration could reasonably be averaged over a $1 \mathrm{~cm}^{2}$ area ... Where actual sensitive manipuiation ... can be proved necessary, the dose might logically be averaged over the fingers." (NCRP 1971)

The ICRP in Publication 9 (1966) recommends a maximum permissible dose of $30 \mathrm{rem} / \mathrm{yr}(0.30 \mathrm{~Sv})$ for the skin. In a period of a quarter of a year, up to one-half of the annual maximum permissible dose can be accumulated. Individual monitoring of workers is recommended for work conditions where the exposure is likely to exceed $30 \%$ of the annual maximum permissible dose. The ICRP further states that for external exposure of the skin, especially when the distance to the source is very short or when the exposed area is very smal1, it would not be appropriate to average the dose over the entire skin area. They recommend instead that the dose be averaged over an area of $1 \mathrm{~cm}^{2}$ in the region receiving the highest dose.

In 1977 the ICRP published new recommendations on radiation protection and limits for occupational exposure. The new recommendations presented in Publication 26 (ICRP 1977) include a dose-equivalent limit for nonstocbastic effects of $50 \mathrm{rem} / \mathrm{yr}(0.5 \mathrm{~Sv})$ for all tissues except the lens of the eye. For stochastic effects, the annual dose enuivalent for irradiation of the whole body is defined as the sum of the product of the annual dose equivalent in each tissue and the corresponding weighting factor. The annual dose equivalent is limited to $5 \mathrm{rem}(0.05 \mathrm{SV})$. For the skin, the ICRP recommended using a range of 50 to $100 \mu \mathrm{m}\left(5\right.$ to $\left.10 \mathrm{mg} / \mathrm{cm}^{2}\right)$ for specifying the depth of the sensitive layer of the skin (ICRP 1977). A depth of $70 \mu m$ was chosen as a reasonable mean value.

The administrator of the EPA, in cooperation with other federal agencies and national councils is in the process of updating the previous guidance written by the FRC (1960) for the protection of workers exposed to ionizing radiation. The new guidance by the EPA is based in part on recommendations of national and international organizations, on the proposed Federal Radiation Protection Guidance for Occupational Exposure of January 1981, on guidance of 
an interagency ad hoc committee, and on public comments about the proposed federal radiation protection guidance. The EPA guidance forms the basis for the draft of the proposed DOE Order 5480.11, Chapter II, "Standards and Requirements for Radiation Protection," which was described earlier.

\subsection{BETA DOSIMETRY}

The physics of beta particle emission and interaction in matter is complex. A beta-emitting nuclide may decay by following one of several pathways, and each pathway resulting in the emission of beta particles having a characteristic maximum beta energy. Foilowing the beta emission, the nuclide sometimes emits one or more gamma rays. In beta decay the energy is shared between the beta particle and a neutrino which leads to a lopsided bell-shaped distribution of beta energies. Since this spectrum is continuous from the maximum energy to zero, small amounts of absorber will quickly alter the lowenergy component of the spectrum and lower the electron flux. This can produce a complex broad-range energy spectrum for the measurement of dose.

The distribution of beta particle energies makes it difficult to calculate the attenuation of beta particles without resorting to complex calculations or computer codes. However, it has been experimentaliy observed that beta particles are exponentially attenuated in low atomic number materials, such as air or tissue, up to a distance corresponding to the range of the maximum beta energy. It is this roughly exponential attenuation that makes it difficult to distinguish beta radiations from Tow-energy ganma rays or x-rays, since most dosimeters rely upon some sort of absorber technioue to distinguish between radiations. Beta particles have a finite range, but gamma rays can penetrate deep into body to deliver dose to critical organs, so it may be necessary to distinguish between gamma rays and beta particles for accurate dosimetry.

Since it is so difficult to distinguish between beta particles and gamma rays, health physicists have developed an alternate method of dealing with the problem by determining the dose at certain critical depths in tissue. Thus, it does not matter what type of radiation is present, one simply measures the dose corresponding to the depth of critical tissues, such as the Tens of the 
eye at a "depth" of $300 \mathrm{mg} / \mathrm{cm}^{2}$ or the basal layer of the skin at a "depth" of $7 \mathrm{mg} / \mathrm{cm}^{2}$. Penetrating radiations are measured at a "depth" of $1000 \mathrm{mg} / \mathrm{cm}^{2}$ or I cm (ICRP 1982).

It is difficult to accurately calculate the dose to tissue from beta irradiations because of the complex abscrption process for bete particles with a continuum of energies, so several methods have been developed to simplify the calculations. The most. well-known methods are the formulas of Loevinger and the dose distribution tabies of Berger.

An excellent review of Loevinger's formula for determining beta dose (Loevinger 1956) is given in "The Mathematica? Theory of Radiation Dosimetry" (Fitzgerald, Brownel1, and Mahoney 1967). Loevinger's formula gives the beta point-source dose-rate distribution in a homogeneous absorbing medium. it consists of two terms involving an effective absorption coefficient for beta particles, which is a complex function of the average beta and maximum beta energies, and the distance from the source. The first term in the formula corresponds to a primary unscattered beta-ray flux, and the second term is associated with the dose rate from a secondary scattered component of the beta flux. Loevinger's empirical fomula has several limitations which restrict its accuracy, including predicting a small dose beyond the range of the beta particle.

Martin Berger has developed empirical tabulations for the absorbed beta dose in tissue and water that are more accurate than the Loevinger formula (Berger 1971). Tables of the fraction of absorbed dose as a function of depth in tissue have been prepared for most common beta emitters and presented in MIRD Pamphiet No. 7 (Berger 1971). More recent computer code calculations (Cross et al. 1982) present tables and graphs of the beta-dose distribution near point and planar sources in water and air for a larger number of nuclides (95) of importance in radiation protection and medicine.

The Berger tables for the absorbed dose distribution from beta particles have been incorporated into the computer code VARSKIN (Traub et a 1.1986 ). This code calculates the absorbed dose to the radio-sensitive basal layer of the skin for beta contaminants, such as ${ }^{3} \mathrm{H},{ }^{14} \mathrm{C},{ }^{11} \mathrm{C},{ }^{85} \mathrm{Kr},{ }^{90} 5 \mathrm{r},{ }^{234^{4}} \mathrm{pa}$, and 234 Th. 
These methodologies can be used to calculate the absorbed beta dose to critical organs. These methods will enable the health physicist to determine whether the dosimeter will properly evaluate the beta dose to critical organs for the beta emitters encountered in the workplace or the beta emitters used in the calibration of the dosimeter.

Beta radiation is a contributor primarily to shallow dose equivalent, or "skin dose," rather than deep dose equivalent. The biologicaliy significant site for the measurement of the shallow dose equivalent is the basal Tayer of actively dividing cells lying below the epidermis. The thickness of superficial tissue lying over these basal cells must be identified so that accurate dosimetric measurements can be obtained from dose-response determinations. The current recommendation from both national and international nrganizations (ICRU 39, ICRP 26, NCRP 39) is that the shallow dose equivalent should be averaged between 5 and $10 \mathrm{mg} / \mathrm{cm}^{2}$ and measured at $7 \mathrm{mg} / \mathrm{cm}^{2}$. A review of radiation effects on the skin and the radiosensitive basal cell layer is given in Section 3.3 of a report by Reece et al. (1985).

Measurement difficulties will occur during routine field measurements of skin dose from 5 to $10 \mathrm{mg} / \mathrm{cm}^{2}$ for two reasons. First, survey instruments with windows approximately $5 \mathrm{mg} / \mathrm{cm}^{2}$ are not sufficientiy rugged for field use and the window may fail during operation. Second, instruments with windows greater than $10 \mathrm{mg} / \mathrm{cm}^{2}$ have limited accuracy due to the attenuation of lowenergy beta particles in the window leading to a strong energy dependence. Current personnel dosimeters may also underestimate beta dose, especially for low-energy beta rays, because of similar problems with the durability of a thin dosimeter plus lowered beta-ray sensitivity and high energv dependence in thick dosimeters. Small amounts of shielding or absorbers can contribute to the wide variations in responses from survey instruments and dosimeters. These complexities, coupled with the geometries involved in the exposure of human tissue, have made accurate detemination of beta radiation dose very difficutt.

In many cases, widely varying geometry and energy considerations have forced health physicists to make oversimplified assumptions when using dosimeters and survey instruments in practical situations in the work place. Where recognized beta doses are present, only the extremity or skin dose 
equivalent has been measured and has usualiy limited the worker's permissible exposures. Since the permissible dose to the hands is 15 times the whole-body limit and the skin limit is three times the whole-body limit, beta dosimetry problems have not been readily apparent and subsequently, have received low priority.

\subsection{METHOOS OF MEASURING BETA DOSE}

At present most beta measuring devices in the field are designed for measurement of other radiations (typically gama). Attempts have been made to adapt these devices for beta dose measurement in the field by the use of correction factors for their calibration and varying assumptions to correct for field differences in geometry and spectra. In general, little effort has been made during the last 20 years to improve the accuracy and precision of dosimeters and instruments used for beta measurement.

\subsubsection{Personnel Dosimeters}

Currentiy, two types of personnel dosimeters are in use: the photographic film dosimeter and the thermoluminescent dosimeter (TLD).

\section{Photographic Film Dosimeters}

The basic property of photographic film dosimeters is an ionizationinduced darkening of emulsion. The dynamic range of the more sensitive fiTms is typically from about $1 \mathrm{mrad}(10 \mu \mathrm{Gy})$ to more than 1 rad $(10 \mathrm{mGy})$, with films available that respond up to the 1 Mrad (10 kGy) region. The intrinsic Iimitations of film are due to four problems: 1) some (unavoidable) background darkening occurs in the absence of any ionization from background radiation; 2) film must be wrapped to avoid light leaks, and even with thin wrappings, the dosimeter is typically insensitive to low-energy beta particles; 3 ) the high average atomic number of typical emulsions makes the response non-tissue-equivalent for low-energy photons; and 4) emulsion darkening ultimately saturates at high doses (and may saturate at low doses for some energies).

Data have also been published from dosimeter intercomparison studies (CEC 1980) that state film is poorly suited for beta dosimetry which uses film casings and coverings of approximately $20 \mathrm{mg} / \mathrm{cm}^{2}$. The measurement of the beta 
emitter ${ }^{147} \mathrm{Pm}(0.224 \mathrm{MeV})$ was determined oniy from the bremsstrahlung emission. It was further documented that a 0.2-mm-thick dosimeter can only measure beta skin dose to $\pm 30 \%$ for beta energies between 20.7 to $3.5 \mathrm{MeV}$. The use of thick coverings would necessitate the use of correction factors to accurately assign personnel dose equivalents.

In a study (Roberson et aI. 1983) of the ability of dosimeters at DOE facilities to meet ANSI N13.11, Draft Criteria for Testing Personnel Dosimetry Performance, the performance of film dosimeters to beta and gamma radiation was shown to be poor. However, the performance of film was better than that of TLDs using the common $230-\mathrm{mg} / \mathrm{cm}^{2}$ LiF chips.

The advantages of $f i$ m include the ability to rescan emulsions after an exposure to determine details of dose deposition, the use of filter shadowing and exposure-uniformity information to measure directionality of exposure and source distance, and the potential for a wide variety of film types and grades.

Besides physical or engineering considerations, two other advantages of film that are often cited are its low unit cost and Iong-term storage (for measurement and lega $\mathrm{I}$ record-keeping).

It has been reported (Chabot, Jimenez, and Skrable 1978) that at least one vendor offers a film specifically for beta dosimetry with varying thicknesses of absorbers that provide information about the electron energy spectrum.

Thermoluminescent Dosimeters

Thermoluminescent dosimeters are composed of inorganjc crystals that contain a high concentration of impurities or defects (knoll 1979). The most common thermoluminescent material for personnel dosimetry used today is Jithium fluoride (LiF) with a thulium activator.

The TLDs have several advantages over photographic film for beta personne? dosimetry:

- reproducible accuracies have been achieved under laboratory conditions

- the dynamic range is large, with doses from about I rad (10 mGy) to we 11 above 100 rad ( 1 Gy) measurable in the same crystal 
- directional uniformity surpasses that of film; it is easier to design a dosimeter to reduce the directional dependence to $\pm 20 \%$ even at low $x$-ray energies

- fading is minimat

- TLDs are rugged and reusable

- Lif can be fabricated in very thin Tayers and requires minimat protective covering, making beta-ray dosimetry possible

- Lif TLDs have a composition that more closely resembles tissue; therefore, the energy dependence is less than that of $f i l m$.

The difficulties of using conventional thick TLD elements to monitor lowenergy beta particles have been well documented (Gesell et al. 1979). Dosimeter elements respond proportionally to the average dose over the thickness of the thermoluminescent (TL) or $\mathrm{fjlm}$ dosimeter. For the dose measurement of nompenetrating radiation, the skin dose should ideally be measured with a tissue-equivalent detector of $5 \mathrm{mg} / \mathrm{cm}^{2}$ thickness covered by a layer of tissueequivalent material $5 \mathrm{mg} / \mathrm{cm}^{2}$ thick. The thicker detection elements normaity used will underestimate the dose of low-energy beta rays by up to $50 \%$. For a detector with an actual thickness of $150 \mathrm{mg} / \mathrm{cm}^{2}$ or $200 \mathrm{mg} / \mathrm{cm}^{2}$, the detection threshold achieved is approximately $0.6 \mathrm{MeV}$ or $0.8 \mathrm{MeV}$ (Oberhofer and Scharmann 1981). Commercially available 0.89-m (35-mil) LiF chips reportedly used by many DOE sites have a density thickness of $230 \mathrm{mg} / \mathrm{cm}^{2}$. Significant errors in underestimating low-energy beta particles are expected from a dosimeter that thick. For ${ }^{90} \mathrm{Sr} /{ }^{90} \mathrm{Y}$ betas, this thickness will underestimate beta dose by a factor of two (Oberhofer and Scharmann 1981). To improve the sensitivity for low-energy beta-ray emitters, different measurement techniques must be adopted. These may include using:

- thinner detectors

- multielement dosimeters so that accurate corrections for selfabsorption can be applied

- surface sensitive elements. 
Scherpelz, Endres, and Rathbun (1983) have shown that even when the particular radionuclides involved are well-characterized, effective beta energies may vary by a factor of three to four, and dose interpretation may vary by a factor of five depending on the type of dosimeters used. Unfortunately, the resultant dose interpretation is usually low (i.e., true beta dose is underestimated). Simons, Gale, and Higginbotham (1983) show that for low-energy beta emitters such as ${ }^{147} \mathrm{Pm}_{\mathrm{m}}\left(\mathrm{E}_{\max }=0.224 \mathrm{MeV}\right)$, some common TLDs have underestimated the actual beta dose by a factor of 27 (Table 1). For nuclides such as ${ }^{85} \mathrm{Kr}\left(\mathrm{E}_{\max }=0.672 \mathrm{MeV}\right)$, the TLD can underestimate dose equivalent by a factor of five. This information indicates that a wide range of beta energies must be monitored at nuclear power plants in the United States. Similar conditions are found in many DOE facilities where the average beta energies vary from $100 \mathrm{keV}$ to well over $500 \mathrm{keV}$ at the same facility. In some cases of unusual geometry, such as point sources, beta doses may be underestimated by a factor of 100 (Hooker et al. 1983).

TABLE 1. Measured Factor for How Much a LiF TLD Would Underestimate the Actuat Beta Dose Relative to the PTB ${ }^{(a)}{ }^{90} \mathrm{Sr} /{ }^{90} Y(E=2.28 \mathrm{MeV})$ Dose (Simons, Gale, and Higginbotham 1983)

\begin{tabular}{|c|c|c|c|c|c|c|c|}
\hline \multirow[b]{2}{*}{$\begin{array}{r}\text { Beta } \\
\text { Source }\end{array}$} & \multirow{2}{*}{\begin{tabular}{c}
\multicolumn{2}{c}{ Maximum } \\
Beta Energy, \\
Mev \\
\end{tabular}} & \multirow{2}{*}{$\begin{array}{c}\text { Cover } \\
\text { Thickness, } \\
\mathrm{mg} / \mathrm{cm}^{2} \\
\end{array}$} & \multicolumn{5}{|c|}{ Average TLD Thickness, $\mathrm{mg} / \mathrm{cm}^{2}$} \\
\hline & & & $\begin{array}{c}235 \\
(\mathrm{LiF}) \\
\end{array}$ & $\begin{array}{l}18.9 \pm 5.3 \\
\text { (LiF) }\end{array}$ & $\begin{array}{c}13.1 \pm 4.2 \\
(\mathrm{LiF})\end{array}$ & $\begin{array}{c}79.3 \pm 2.8 \\
\left({ }^{7} \mathrm{LiF}\right)\end{array}$ & $\begin{array}{c}24.7 \pm 7.8 \\
\left({ }^{6} \mathrm{tiF}\right)\end{array}$ \\
\hline \multirow[t]{2}{*}{${ }^{147} 7_{\mathrm{Pm}}$} & $0.225^{(a, b)}$ & 0 & - & 2.91 & 2.24 & 2.80 & 3.44 \\
\hline & & 1.4 & 27.4 & 4.27 & 3.31 & 3.89 & 4.89 \\
\hline \multirow[t]{4}{*}{${ }^{204} \mathrm{Tl}$} & $0.76^{(a)}$ & 0 & - & 1.13 & 1.04 & 1.09 & 1.12 \\
\hline & & 1.4 & 3.93 & 1.17 & - & - & - \\
\hline & & 14.5 & 5.15 & - & 1.44 & - & - \\
\hline & & 27.6 & - & - & - & 1.97 & - \\
\hline $85_{K r}$ & 0.690 & 1.4 & 3.38 & 1.11 & - & - & 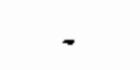 \\
\hline${ }^{106} \mathrm{Ru} /{ }^{106} \mathrm{Ph}$ & 3.54 & 1.4 & 1.04 & 1.01 & - & - & - \\
\hline
\end{tabular}

(a) Physikaitisch Technische Bundesanstalt (PTB) sources.

(b) The maximum beta energy was much less than this value at the TLD position. 
Inadequacies in beta measurements are further demonstrated by Rathbun et a1. (1983) in a study to determine the accuracy of beta radiation measurements at NRC-Ticensed facilities. As part of this study, both calibration scurces and beta fields characterized with spectrometers were used to study the response of commercial dosimeters. As shown in Table 2, the dosimeter response to calibration sources was highly variable. In some cases, the dosimeter did not respond at all to a given source. Of particular concern to DOE facilities is the very low response of commercial dosimeters to a uranium slab source. As shown in Table 3, the variability in dosimeter response is even greater in the field than in the laboratory. The dosimeter response is generally low; in some cases, by a factor of as much as 100 . There are also numerous cases of no dosimeter response for doses ranging from 100 mrad (1 $\mathrm{mGy}$ ) to $22,000 \mathrm{mrad}$ ( $20 \mathrm{mGy}$ ). Most likely, this lack of response is due to scatter and degradation of the beta spectrum when beta particles interact with materials in the field environment.

TABLE 2. Commercial Dosimeter Responses to Beta Calibration Sources (Rathbun et a1. 1983)

\begin{tabular}{|c|c|c|c|c|c|c|c|c|c|c|}
\hline \multirow{2}{*}{$\begin{array}{l}\text { PNL } \\
\text { Beta } \\
\text { Source } \\
\end{array}$} & \multirow{2}{*}{$\begin{array}{l}\text { Beta }(a) \\
\text { Exposure, } \\
\text { mrad } \\
\end{array}$} & \multicolumn{9}{|c|}{ Dosimeter } \\
\hline & & $\begin{array}{c}\text { A, } \\
\text { mrad }\end{array}$ & $\begin{array}{c}\text { B, } \\
\text { ar ad }\end{array}$ & $\begin{array}{c}\mathrm{C}, \\
\text { mrad }\end{array}$ & $\begin{array}{c}0, \\
\text { mrad }\end{array}$ & $\begin{array}{r}E, \\
\operatorname{mrad}\end{array}$ & $\begin{array}{c}F, \\
m r \text { ad }\end{array}$ & $\begin{array}{c}G, \\
\text { mrad }\end{array}$ & $\begin{array}{c}\mathrm{H}, \\
\mathrm{mrad}\end{array}$ & $\begin{array}{c}\text { T, } \\
\text { mrad }\end{array}$ \\
\hline U slab & 100 & 63 & $\mathrm{ND}^{(\mathrm{b})}$ & 31 & 34 & 5 & 0 & 0 & ND & ND \\
\hline U slab & 300 & 112 & 95 & 106 & 108 & 50 & 0 & 105 & ND & 90 \\
\hline U slab & 675 & 234 & 232 & 198 & 212 & 160 & 0 & 0 & ND & ND \\
\hline \multirow{3}{*}{$\begin{array}{c}451 \text { ab } \\
90_{5 r} \\
90_{5 r}\end{array}$} & 4,000 & 1,487 & 1,430 & 1,295 & 1,350 & 1,040 & 60 & 55 & ND & NO \\
\hline & 2,000 & ND & 1,934 & ND & 1,057 & 1,345 & 152 & 150 & 7,050 & 0 \\
\hline & 1,000 & 901 & ND & 604 & ND & NO & ND & ND & ND & ND \\
\hline${ }^{147} 7_{\mathrm{Pm}}$ & 250 & 54 & 396 & 5.5 & 6.5 & 60 & 0 & 0 & 95 & 12 \\
\hline${ }^{204} \mathrm{TI}$ & 1,000 & 1,000 & 632 & 284 & 116 & 205 & ND & ND & 2,400 & ND \\
\hline${ }^{204} \mathrm{TI}$ & 500 & 694 & 336 & ND & $N D$ & ND & ND & ND & ND & 3 \\
\hline
\end{tabular}

(a) Measured with a deeply depleted silican (Si) surface barrier detector. (b) ND indicates that na dosimeter was exposed. 
TABLE 3. Response of Commercial Dosimeters to Beta Radiation at NRC-Licensed Facilities (Rathbun et al. 1983)

\begin{tabular}{|c|c|c|c|c|c|c|c|c|c|c|}
\hline \multirow[b]{2}{*}{ Site } & \multirow[b]{2}{*}{ Location } & \multirow{2}{*}{$\begin{array}{c}\text { Beta } \\
\text { Exposure } \\
\text { mrad } \\
\end{array}$} & \multicolumn{8}{|c|}{ Dos imeter } \\
\hline & & & $\begin{array}{l}\text { A, } \\
\text { mrad }\end{array}$ & $\begin{array}{c}\text { B, } \\
\text { mrad } \\
\end{array}$ & $\begin{array}{c}\mathrm{C}, \\
\text { mrad } \\
\end{array}$ & mrad & $\begin{array}{r}\text { E, } \\
\text { mrad }\end{array}$ & mrad & $\begin{array}{c}\text { G, } \\
\text { mrad }\end{array}$ & $\begin{array}{c}P_{3} \\
\text { mrad }\end{array}$ \\
\hline$Q-2$ & Uranium slab & 100 & 0 & 636 & 76 & $\mathrm{ND}(\mathrm{b})$ & 30 & 0 & 0 & 0 \\
\hline $0-2$ & Contaminated wheel & 500 & 270 & 300 & 65 & 0 & 250 & 0 & 0 & 1,650 \\
\hline $0-2$ & Contaminated 1 ight & 9,910 & 0 & 8,772 & 0 & ND & 0 & 1,350 & 120 & ND \\
\hline $\mathrm{N}-1$ & Pipe & 20,000 & 208 & 495 & ND & ND & ND & ND & ND & ND \\
\hline $0-1$ & $\begin{array}{l}\text { Contaminated con- } \\
\text { crete wol } f^{(c)}\end{array}$ & 2,600 & 3,568 & 8,772 & 635 & ND & 1,530 & 2,600 & 630 & ND \\
\hline$D-1$ & $\begin{array}{l}\text { Liquid naste storage } \\
\text { area }\end{array}$ & 40 & ND & 732 & 151 & ND & 810 & 1,320 & 1,050 & ND \\
\hline $0-1$ & $\begin{array}{l}\text { Liquid maste storage } \\
\text { area }\end{array}$ & 170 & 500 & 0 & 0 & ND & 1,055 & 1,760 & 865 & ND \\
\hline $0-1$ & $\begin{array}{l}\text { Liquid maste storage } \\
\text { area }\end{array}$ & 450 & 92 & ND & 0 & ND & 1,280 & 1,850 & $?, 200$ & ND \\
\hline $0-2$ & $\begin{array}{l}\text { Liquid naste storage } \\
\text { area }\end{array}$ & 230 & 0 & 0 & 110 & ND & 0 & 81 & 74 & 38 \\
\hline $0-2$ & $\begin{array}{l}\text { Contaminated } \\
\text { concrete }^{(c)}\end{array}$ & 1,800 & 3,013 & 0 & 804 & 608 & 540 & 0 & 1,300 & 4,900 \\
\hline $0-2$ & $\begin{array}{l}\text { Contaminated } \\
\text { concrete } \\
(c)\end{array}$ & 750 & 1,500 & 3,195 & 0 & 0 & 905 & 1,500 & 1,500 & 2,000 \\
\hline$R-2$ & $\begin{array}{l}\text { Pellet boat } \\
\text { storage }\end{array}$ & 2,100 & 708 & 440 & 592 & ND & 35 & 30 & 1,300 & ND \\
\hline$R-2$ & $\begin{array}{l}\text { Pellet boat } \\
\text { storage }^{(d)}\end{array}$ & 690 & 226 & 222 & 262 & ND & 20 & 20 & 250 & ND \\
\hline
\end{tabular}

(a) Measured with a deeply depleted silicon (Si) surface barrier detector.

(b) ND indicates that no dosimeter was exposed.

(c) ${ }^{137} \mathrm{Cs}_{\mathrm{s} \text {-contaminated. }}$

(d) $\mathrm{UO}_{2}$ pellets. 


\section{IdeaI Beta Dosimeter}

From many of the inadequacies of existing beta-dose measurement, the theoretical properties of an ideal beta dosimeter have been determined. Tabie 4 identifies these properties.

\section{TABLE 4. Properties of the Ideal Beta Dosimeter (after Kiotz 1984; Portal 1984)}

\section{Property}

Uniform sensitivity

Envirommentat insensitivity

Low-energy insensitivity

Alpha, ganma, and neutron insensitivity

Background-radiation insensitivity

Unintended-radiation insensitivity

Self-irradiation protection

Linear dose/response relationship

Response/dose-rate independence

Precise beta-dose calculability

Contamination protection

Efficient physicai design

\section{Explanation}

Dosimeter reading unaffected by directional or spatial changes within radiation field $4 \pi$ sensitivity

Stored dose information unaffected by adverse temperature or humidity; in the work environment, temperature may range from -40 to $100^{\circ} \mathrm{C}$ and relative humidity may range from $0 \%$ to $100 \%$

Insensitive to photons of about $5-\mathrm{keV}$ energy or less; protects against lost, induced, or modified signal when dosimeter is exposed to very low-energy $x$-ray, ultraviolet, visible, infrared, or microwave and radio-frequency radiations

Insensitive to al pha, gamma, and neutron radiations to eliminate interference from other components of an ionizing radiation field

insensitive to radiations not produced by materials or activities the employer or 1 icensee at the facility where occupational exposure of the morker is being monitored

Insensitive to all radiation while not being worn to monitor occupational exposure; should have an on/off switch for sensitizing the cosimeter while in use and desensitizing it men not in use

Components of the dosimeter should not be radioactive

Dosimeter should be able to be fully calibrated over entire dose range men the dose/response relationship is accurately determined at just one dose

Response should be independent of dose rate so that signal from dosimeter's sensitive element depends solely on the dose the worker received during the monitoring period

Beta dose should be readily and accurately determined as a function of depth in tissue from $0.007 \mathrm{~cm}$ to $1 \mathrm{~cm}$

Protected against contamination adhering to the outer surface of the dosimeter that could contribute to the radiation-induced signal

Confortable to wear (sma)!, Iightweight, no interference mith worker's activities) and easy to attach and remove 
TABLF. 4. (contd)

Property

Element accessibility

Proper labe11ng

Manuf acturabllity

Repeatabjlity

Batch homogenity

Detection threshold

Heasurement range

Remanence

Minimal fading

\section{Explanation}

Dosimeter's sensitive element should be readily accessible to authorized personnel for ease of disassembly and the potential for rapid processing

Identification label should be well protected, highly visible, and easy to attach and remove

Should be capable of being uniformiy mass produced at a low cost

Dosimeter should yield the same reading between successive evaluations under the same conditions

Closeness of agreement of results made on a sampling of a single batch of dosimeters that are exposed and analyzed under the same conditions

Low minimum dose detection point

Wide range capability of dosimeter

Residual information retained after dosimeter has been reset to zero

Stability of dosimeter over long time periods

\subsubsection{Portable Survey Instruments}

For general survey work the most commonly used beta instrument is an ionization chamber with a thin window that permits penetration of beta particles. In a gas-filled detector, the chamber is usually filled with gas at pressure slightly more than one atmosphere.

Windows on gas-filled detectors are commonty plastic film, such as Mylar, with a vacuum-evaporated conducting surface on the inside. For survey use, Geiger-Mueller (GM) tubes usually employ one or two special mixtures as the counting gas: $98.7 \%$ helium $+1.3 \%$ butane or $99.05 \%$ helium $+0.95 \%$ isobutane. Proportional counters use either pure methane or a mixture known as $\mathrm{P}-10$ gas ( $90 \%$ argon 10\% methane) (ICRU 1972).

The chief use of a GM counter should be to detect and establish the relative magnitude of beta fields. Because the GM counter indicates only the number of particles, not their energy, it yields onty an approximate dose. 
The problems encountered using beta survey instruments are similar to those identified for personnel dosimeters. Beta dose rates obtained from most survey instruments are the result of taking two instrument readings. One reading is taken with the instrument detector window open (gross reading) and a second reading with the window closed (gamma reading). The net reading is obtained by subtracting the gamma reading from the gross reading. This number is then muttiplied by a beta factor to obtain a beta dose rate. A beta factor of approximately four is commonly used at many DOE sites and in the commercial nuclear industry. This factor is derived by placing a survey instrument in contact with a natural uranium slab and obtaining a reading. Dividing this reading into the known contact dose rate yields the beta factor. Unfortunately, this methodoiogy yields a beta factor that is not representative of all beta fields found in the workplace. The beta factor is a function of the shape and the endpoint energy of the specific beta spectrum, and the uranium slab is not a representative spectrum for all fields.

Ideally the beta factor should be determined before each fieid measurement is obtained. Survey instruments currently available cannot provide this factor, so the only alternative is to use a constant factor. It must be recognized that beta dose rates obtained in any survey using beta factors will likely be in error, and the magnitude of the error will be unknown.

Because of the low penetrating power of beta radiation, most current survey instruments are designed with thin windows so that the beta radiation can penetrate to the sensitive element of the detector. These windows, along with the side walls of the detector volume, introduce a strong angular response in the survey instrument. For normally incident radiation, a survey instrument will correctly estimate the beta dose rate. If the radiation is isotropic, however, such an instrument will substantially underestimate the dose rate.

Additional errors can be introduced by using uranium slabs as instrument calibration sources. Current practices for instrument calibration with an uranium slab require placement of the survey instrument with its window in contact with the slab. Beta dose rates are constant only for a few millimeters above the slab surface (Kathren 1975) and fall off to only $4 \%$ of their surface value at $10 \mathrm{~cm}$ from the slab. Unless the detector's sensitive 
volume is only a few millimeters deep, the radiation field in the sensitive volume will not be uniform. Most detectors available today have sensitive volumes greater than a few millimeters deep. Some are 5 to $10 \mathrm{~cm}$ or more deep. In these cases the average measured dose rate will be significantly lower than the dose rate of the uranium slab. While the beta factor for surface dose is used to compensate for this problem, the perturbation of the beta field from the detector and the nonuniform field produce an unfavorable geometry for instrument calibration. Tables 5 and 6 provide examples of the errors that could occur if appropriate geometry corrections are not made (Hooker et aI. 1983). One further problem is that the uranium siab emits gamma radiation as well as beta radiation. This contributes about $10 \%$ of the dose rate at the surface of the uranium slab and increases to approximately $20 \%$ at $10 \mathrm{~cm}$ (Kathren 1975). Because of this nonuniform photon contribution, accurate compensation factors are difficult to determine, and in most cases none have been made.

As shown in Table 7, the variation between the actual dose rate and the dose rate determined by using commercial survey instruments ranged from a factor of almost eight low to over a factor of three high (Rathbun et al. 1983).

TABLE 5. Examples of Correction Factors Used when Measuring ${ }^{90} \mathrm{Sr} / 90_{\mathrm{Y}}$ Disk Sources with a "Cutie Pie" Ion Chamber Survey Instrument ${ }^{(a)}$ (Hooker et al. 1983)

Source Diameter

\begin{tabular}{cccc}
\multicolumn{5}{c}{ Source-window Distance } \\
\hline Contact & $\frac{1 / 2 \text { inch }}{1 \text { inch }}$ & 6 inches \\
90 & 9 & $\frac{1.9}{1}$ \\
35 & 5 & 2.0 & 1 \\
4.5 & 2.6 & 2.2 & 1 \\
4.5 & 2.5 & 2.3 & 1.3 \\
4.5 & 2.5 & 2.5 & 2.3
\end{tabular}

$1 / 2$ inch

1 inch

6 inches

1 foot

4.5

2.5

2.5

2.3

(a) In order to obtain the beta exposure/dose rate at the detector window, multiply the meter reading by the applicable correction factor. 
TABLE 6. Examples of Rectangular Volume Correction Factors for a "Juno" Survey Meter Exposed to ${ }^{90} \mathrm{Sr} /{ }^{90} \mathrm{Y}$ Disk Sources $^{(a)}$ (Hooker et al. 1983)

Source

Diameter

$1 / 2$ inch

1 inch

6 inches

1 foot

6 feet

\begin{tabular}{lcc} 
& Source-Window Distance \\
\hline Contact & $\frac{1 / 2 \text { inch }}{1 \text { inch }}$ & $\frac{1}{2.1}$ \\
86 & 7 & 2.0 \\
31 & 5 & 1.5 \\
2 & 1.6 & 1.7 \\
2 & 1.8 & 1.8 \\
2 & 1.0 & \\
\\
obtain the beta dose rate at the detector \\
tiply the meter reading by the applicable \\
factor.
\end{tabular}

(a) In order to obtain the beta dose rate at the detector window, multiply the meter reading by the applicable correction factor.

TABLE 7. Response of Commercial Survey Instruments to Beta Fields at NRC-Licensed Facilities (Rathbun et a T. 1983)

\begin{tabular}{|c|c|c|c|c|c|c|c|c|c|}
\hline Site & Location & $\begin{array}{l}\text { Beta }{ }^{(a)} \\
\text { Dose, } \\
\mathrm{mrad} / \mathrm{h}\end{array}$ & $\bar{A}$ & $\begin{array}{l}\text { urve } \\
\text { ta } R \\
B\end{array}$ & $\begin{array}{l}\text { Instr } \\
\frac{\text { dings }}{C}\end{array}$ & $\begin{array}{l}\text { nent } \\
\frac{m r a d}{D} / h\end{array}$ & $E$ & $\begin{array}{l}\text { Wintow to } \\
\text { Source } \\
\text { Distance }\end{array}$ & Comment \\
\hline$R-1$ & $\begin{array}{l}\text { Uranium pellet } \\
\text { boat }^{(b)}\end{array}$ & 200 & 69 & 420 & 38 & 59 & ${ }_{N D}(c)$ & $3 \mathrm{in}$. & $\begin{array}{l}\text { Fuel Fab. Facility } \\
\text { operating }\end{array}$ \\
\hline$R-1$ & $\begin{array}{l}\text { Uranium pellet } \\
\text { tray (b) }\end{array}$ & 210 & ND & 400 & 465 & 76 & 70 & 3 in. & $\begin{array}{l}\text { Fuel Fab. Facility } \\
\text { operating }\end{array}$ \\
\hline$R-2$ & $\begin{array}{l}\text { Uranium powder } \\
\text { bucket }\end{array}$ & 67 & 20 & 155 & 13 & 24 & 9 & 9 in. & $\begin{array}{l}\text { Fuel Fab. Facility } \\
\text { operating }\end{array}$ \\
\hline$R-2$ & $\begin{array}{l}\text { Uranium pomder } \\
\text { bucket }\end{array}$ & 97 & 32 & 184 & 23 & 34 & 15 & $7 \mathrm{in.}$ & $\begin{array}{l}\text { Fuel Fab. Facility } \\
\text { operating }\end{array}$ \\
\hline$R-2$ & $\begin{array}{l}\text { Uranium pellet } \\
\text { boat }^{(b)}\end{array}$ & 230 & 74 & 530 & 45 & 45 & 29 & 3 in. & $\begin{array}{l}\text { Fuel Fab. Facility } \\
\text { operating }\end{array}$ \\
\hline
\end{tabular}

(a) Heasured with a deeply depleted silicon (Si) surface barrier detector.

(b) $\mathrm{UO}_{2}$ pellets.

(c) ND indicates that no dosimeter mas exposed. 
Proper instrument calibrations cannot be accomplished in the working environment where the type and energy of beta radiations are not known. Rugged, accurate, beta energy spectrometers designed for field use are virtually nonexistent. Thus, energies cannot be adequately defined to ensure that instruments are calibrated to the appropriate energies.

No national beta caljbration standards are currently available from the National Bureau of Standards (NBS). Recently, sources that are traceable to the German Physikalisch Technische Bundesanstalt (PTB) have been purchased by some DOE contractors. The International Organization for Standardization (ISO) has specified five radionuclides that should be used for the calibration of beta radiation measuring instruments (ISO 1983). These five radionuclides $\left({ }^{14} \mathrm{C},{ }^{90} \mathrm{Sr} /{ }^{90} \mathrm{Y},{ }^{106} \mathrm{Ru} /{ }^{106} \mathrm{Rh},{ }^{147} \mathrm{Pm}\right.$, and $\left.{ }^{204} \mathrm{~T} 1\right)$ have recently been adopted for use by NBS. The beta radiation fields produced by all these nuclides, except ${ }^{106} \mathrm{Ru} /{ }^{106} \mathrm{Rh}$, are virtually free of photon radiation except for bremsstrahlung generated in the surrounding materials or in the beta source itself. The ${ }^{106} \mathrm{Ru} /{ }^{106} \mathrm{Rh}$ nucijide was chosen because of its high $E_{\max }$ energy. When dose rates that are uniform over a large area (20-cm diameter) are required, beamflattening filters must be used in conjunction with a specified source. When high dose rates are required during calibrations, beam-flattening filters are not used with the reference standard. The distance from the source to the detector is important for these irradiations to ensure that a uniform field is produced.

In addition to primary calibration, it is essential that survey instruments receive periodic performance tests. For examples, see ANSI N323 (1978). These in-house tests ensure proper operation of the instrument. The tests should be performed and documented as soon after the primary calibration as possible to establish baseline data for response of the instrument while it is operating properly. Depending on the instrument usage, performance tests should be conducted on at least a monthly basis. Documenting the results is very important because changes in response indicate problems that may require repair and/or recalibration before the instruments function adequately. 
The ANSI N323 (1978) states that "when the instrument response to the check source differs from the reference reading by more than $\pm 20 \%$, the instrument shall be returned to the calibration facility for calibration or for maintenance, repair, and recalibration, as required." If this criterion is not followed, the readings from portable survey instruments (or any radiological measuring instrumentation) cannot be relied on to ensure the health and safety of the workers. 


\subsection{BETA SURVEY RESULTS}

As part of an effort to characterize DOE's capabilities in beta detection and dose measurement, a questionnaire was developed to solicit information from DOE and DOE contractor facilities that have beta measurement programs. Twenty-nine facilities responded to this survey, describing their measurement programs. The types of facilities surveyed include uranium enrichment plants, fuel fabrication and processing plants, weapons fabrication sites, research laboratories, accelerators, and reactors.

Table 8 lists the 29 facilities that returned the questionnaire. One facility indicated that they did not currently have or anticipate possessing any beta-emitting radionuclides although they did have instrumentation that might be suitable for beta detection. The responses from this facility were not included in the summary of the survey results. Thus, the compiled data and the following summary based on 28 of 29 survey respondents. The compiled response data is presented in Appendices $A$ and $B$. In the appendices, respondents are identified with an alphabetical designation ( $A$ through $C C$ ) based on when the completed questionnaire was received for analysis. Detailed responses provided by some of the facilities to specific questions are also noted in Appendix $A$.

Specific areas of interest covered in the questionnaire and discussed in this report include:

- generai characteristics of measurement programs

- identification of personnet dosimeters for beta dose assessment

- calibration of personnel dosimeters

- quality controi processing of personnel dosimeters

- identification of radiation protection instrumentation routinely used to detect and/or measure beta activity

- calibration of radiation protection instruments

- periodic performance testing parameters for radiation protection instrumentation. 
TABLE 8. DOE Facilities Included in Study

DOE Facjlity

Argonne National Laboratory

Argonne National Laboratory West

8rookhaven National Laboratory

EG\&G Idaho, Inc.

EXXON Nuclear Idaho Co., Inc.

Fermi National Acceleration Laboratory

Goodyear Atomic Corporation

Hanford Engineering and Development Laboratory

Inhalation ToxicoTogy Research Institute

Lawrence Berkeley Laboratory

Lawrence Livermore Mational Laboratory Nevada Test Site

Los Alamos National Laboratory

Mound Laboratory

NLO, Inc., Feed Materials Production Center

Oak Ridge Gaseous Diffusion Plant

Oak Ridge Y-12 Plant

Pacific Northwest Laboratory

Paducah Gaseous Diffusion Plant

Pinellas Plant

Princeton Plasma Physics Laboratory

Reynolds Electrical and Engineering Co. Nevada Test Site

Rockwell Hanford Operations

Rocky Flats Plant

Sandia National Laboratories Albuquerque

Sandia Nationa? Laboratories Livermore

UNC Nuclear Industries, Inc.

Union Carbide Corporation

U.S. Department of Energy Idaho Operations Office

U.S. Department of Energy

New Brunswick Laboratory
Location

Argonne, Illinois

Idaho Falls, Idaho

Upton, New York

Idaho Falls, Idaho

Idaho Fa?ls, Idaho

Batavia, IlTinois

Piketon, Ohio

Richland, Washington

Albuquerque, New Mexico

Berkeley, California

Mercury, Nevada

Los Alamos, New Mexico

Miamisburg, Ohio

Cincinnati, Ohio

Oak Ridge, Tennessee

Oak Ridge, Tennessee

Richland, Washington

Paducah, Kentucky

St. Petersburg, Florida

Princeton, New Jersey

Las Vegas, Nevada

Richland, Washington

Golden, Colorado

Albuquerque, New Mexico

Livermore, Cal ifornia

Richiand, Washington

Oak Ridge, Tennessee

Idaho Falls, Idaho

Argonne, Illinois 


\subsection{GENERAL CHARACTERISTICS OF BETA MEASUREMENT PROGRAMS}

Twenty-six of the 28 facilities summarized in this report indicated that they had a beta monitoring program in place. One facility was developing a beta program for future implementation, another facility indicated that they did not have a program in place for monitoring beta activity. The latter facility did have appropriate instrumentation available for beta detection and measurement although they did not discriminate between beta/gamma activity. The only beta emitters of concern at this facility were identified as being encountered infrequently and would not create a significant radiological hazard.

The number and diversity of beta-emitting nuclides at a specific site is highly dependent on the site's operations. As would be expected, facilities that performed operations related to the nuclear fuel cycle (e.g., fuel reprocessing) reported the greatest number of beta-emitting nuclides. Research laboratories and accelerators report the fewest.

Figure 1 identifies the predominant beta-emitting radionuclides reported at DOE facilities. Table $g$ outlines the major characteristics of these radionuclides. The most commonly reported radionuclides were tritium ( 9 facilities) and ${ }^{90} \mathrm{Sr} /{ }^{90} \mathrm{Y}$ ( 9 facilities), followed by mixed fission products (6 facilities) and ${ }^{14} \mathrm{C},{ }^{99} \mathrm{Tc},{ }^{137} \mathrm{Cs}$, and ${ }^{234} \mathrm{Th}$ ( 5 facilities each).

Approximately $35 \%$ of the survey respondents indicated that beta-emitting radionuclides limit radiation protection requirements at their facilities (i.e., nonpenetrating exposures were a higher fraction of the dose limit than were penetrating exposures). As shown in Figure $1,{ }^{90} \mathrm{Sr} /{ }^{90} \mathrm{Y}$ and ${ }^{234 \mathrm{~m}} \mathrm{~Pa}$ were limiting at three facilities; ${ }^{234}$ Th and ${ }^{238} \mathrm{U}$ at two facilities each.

\subsection{PERSONNEL DOSIMETERS FOR BETA ASSESSMENT}

The basic requirement of a dosimeter system for individual monitoring is that it should permit the estimation of the dose equivalent received with reasonable accuracy over the whole range of radiations and energies and of dose equivalents and dose equivalent rates likely to be encountered in normal and abnormal conditions (ICRP 1982). 


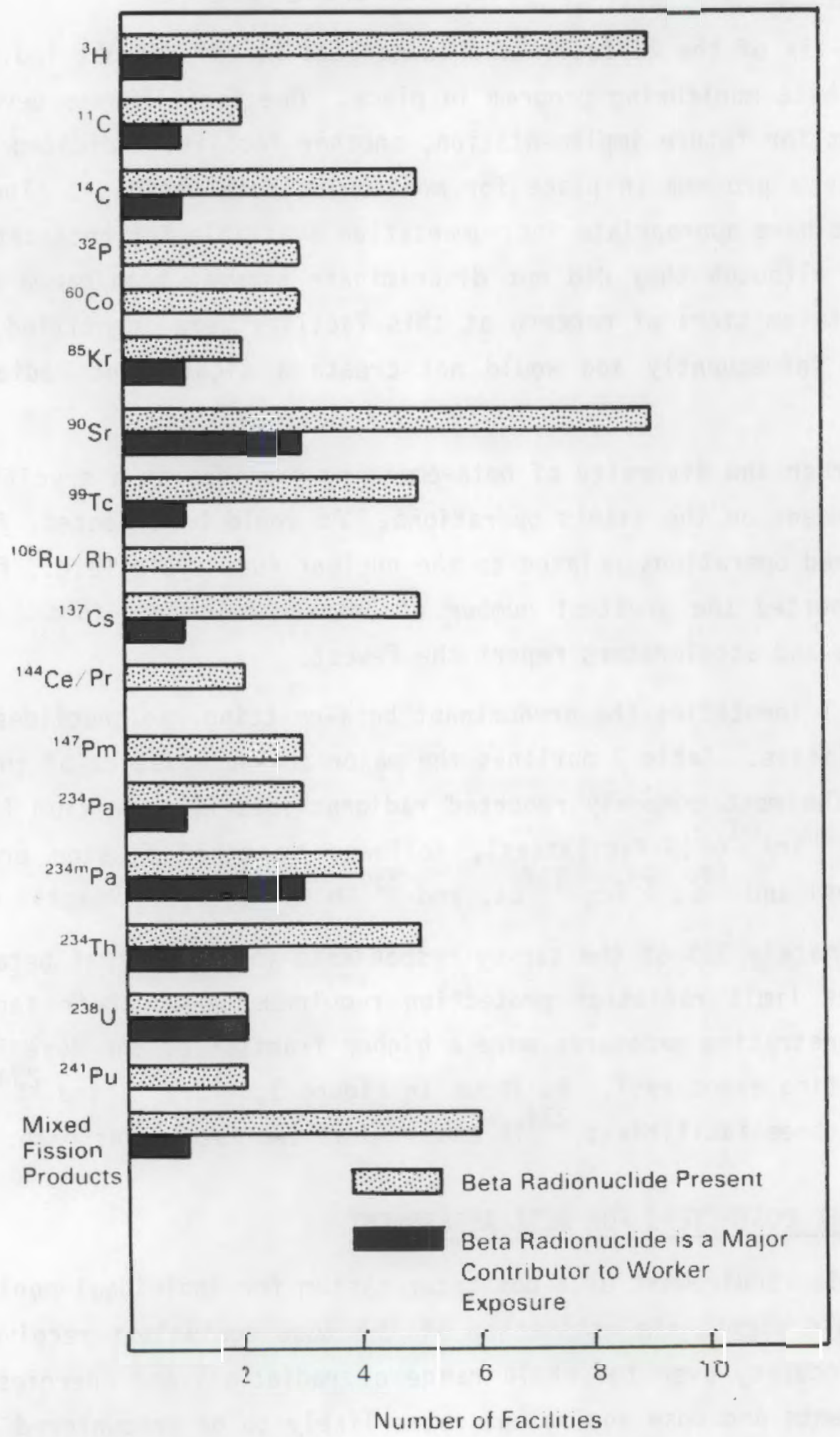

FIGURE 1. Predominant Beta-Emitting Nuclides Found at DOE Facilities 
TABLE 9. Characteristics of Beta-Emitting Radionuclides Found at DOE Facilities

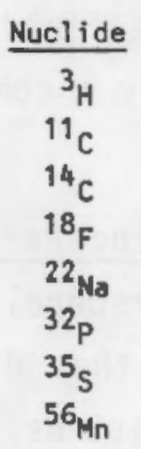

${ }^{60} \mathrm{Co}$
${ }^{85} 5_{\mathrm{Kr}}$
${ }^{85} \mathrm{~m}_{\mathrm{Kr}}$
${ }^{90}{ }_{5 r}$
${ }^{90} \mathrm{Y}$
${ }^{99} \mathrm{Tc}$
${ }^{106} \mathrm{Ru}$
${ }^{106} \mathrm{Rh}$
${ }^{125} \mathrm{Sb}$

131,

$137 \mathrm{Cs}$

${ }^{144} \mathrm{Ce}$

${ }^{144} \mathrm{Pr}$

${ }^{147} \mathrm{Pm}$

${ }^{154} \mathrm{Eu}$

${ }^{155}$ Eu

${ }^{231}$ Th

${ }^{234} \mathrm{~Pa}$

$234 \mathrm{mpa}_{\mathrm{Pa}}$

${ }^{234} \mathrm{Th}$

${ }^{241} \mathrm{Pu}$
Half-Life

$12.4 \mathrm{yr}$

$20.4 \mathrm{~min}$

$5,730 \mathrm{yr}$

$110 \mathrm{~min}$

$2.6 \mathrm{yr}$

$14.3 \mathrm{~d}$

$87.4 d$

$2.6 \mathrm{~h}$

$5.2 \mathrm{yr}$

$10.7 \mathrm{yr}$

$4.5 \mathrm{~h}$

$28.5 \mathrm{yr}$

$64.0 \mathrm{~h}$

$2.1 \times 10^{5} \mathrm{yr}$

$368 \mathrm{~d}$

$30 \mathrm{sec}$

$2.8 \mathrm{yr}$

$8.0 \mathrm{~d}$

$30.2 \mathrm{yr}$

$284 d$

$17.3 \mathrm{~min}$

$2.62 \mathrm{yr}$

$16.0 \mathrm{yr}$

$4.96 \mathrm{yr}$

$25.5 \mathrm{~h}$

$6.7 \mathrm{~h}$

$1.2 \mathrm{~min}$

$24.1 d$

$13.2 \mathrm{yr}$
Major Beta

Radiation

$E_{\text {max }}, \mathrm{MeV}$

0.0185

0.96

0.156

0.634

0.545

1.71

0.167

2.85

1.04

0.735

0.318

0.687

0.841

0.546

2.28

0.294

0.039

3.54

0.622

0.304

0.095

0.608

0.512

0.315

0.182

3.00

0.224

1.85

0.847

0.577

0.255

0.159

0.141

0.306

0.206

1.14

0.654

0.486

2.28

0.193

0.101

0.021
Percent

Emisson

100

99.8

100

96.7

89.8

100

100

56.3

27.9

14.6

99.9

99.6

78.8

100

100

100

100

78.9

13.5

40.2

13.5

89.3

94.8

75.9

19.8

92.9

100

12.17

16.9

36.5

27.7

25

46

78

16.1

10

18

38

98.7

72.5

17.6

100 
Thermoluminescent dosimeters are used at 24 of the facilities and film dosimeters at 8 of the facilities. Five of the facilities use both TLDs and film dosimeters. These personnel dosimeters were processed by in-house personnel at 14 of the facilities, by another contractor in the field office at 4 of the facilities, by vendors at 4 of the facilities, or by a commercial laboratory at 3 of the facilities.

The ANSI N13.11 (1983) standard, Draft Criteria for Testing Personnel Dosimetry Performance, was used in the calibration of these personnel dosimeters at seven of the sites. Seven facilities responded that they did not follow any standards or guides for personnel dosimeter calibrations. When this questionnaire was distributed, there was no formal national calibration accreditation program in existence. Since that time, however, the National Voluntary Laboratory Accreditation Program (NVLAP) and DOE Laboratory Accreditation Program (DOELAP) have been instituted to improve the reliability of these calibrations.

The beta radiation sources used to calibrate personnel dosimeters are shown in Table 10. The predominant source was a uranium slab.

TABLE 10. Radiation Sources Used to Calibrate Personnel Dosimeters

\begin{tabular}{|c|c|}
\hline Source & $\begin{array}{l}\text { Number of } \\
\text { Facilities }\end{array}$ \\
\hline Depleted uranium & 4 \\
\hline Natural uranium & 2 \\
\hline Uranium slab & 8 \\
\hline${ }^{90} \mathrm{Sr} /{ }^{90} \mathrm{Y}$ & 10 \\
\hline None & 1 \\
\hline
\end{tabular}

\subsubsection{Thermoluminescent Dosimeters}

Eight of the facility respondents used a commercially designed TLD system. The majority of the facilities utilizing a multiple TLD used a chip dosimeter with varying types of filters. The density thickness of the absorber material covering the chip used to assess beta radiation was reported to be $5 \mathrm{mg} / \mathrm{cm}^{2}$ to $439 \mathrm{mg} / \mathrm{cm}^{2}$. For standard $0.89-\mathrm{mm}$ (35-mil) Lif chips this 
thickness equals a density thickness of $235 \mathrm{mg} / \mathrm{cm}^{2}$ to $669 \mathrm{mg} / \mathrm{cm}^{2}$. Density thicknesses of this magnitude cannot accurately characterize beta dose unless a correction factor is applied. This survey did not request any information on correction factors. Three of the respondents reported using a single-chip dosimeter for beta dose assessment.

The calibration of TLDs was performed in large batches at 11 of the facilities. Seven of the facilities calibrated individual chips. To achieve the best results from TLD systems, it is desirable to obtain a large batch of dosimeters that have well-matched responses to the radiation spectrum of the beta sources and to calibrate individual chips.

The ICRP Publication 35 (1982) states that a LiF two-element dosimeter, with one element covered by a tissue-equivalent filter, is a suitable dosimeter for determining the dose equivalent between surface and fixed depth at about $10 \mathrm{~mm}$.

A multielement dosimeter with either film or TL elements with filter materials of different atomic numbers and thicknesses is an example of a dosimeter that gives some indication of the types of radiation and their effective energies. Without correction it will give an overestimate of the dose equivalent to most organs and tissues. The effects of this overestimate are negligible except for low-penetrating-power radiation. The skin dose is then likely to be limiting.

It is important to note that a simple film badge or a TLD containing elements of higher atomic number with one filtered and one unfiltered area is not an effective two-element dosimeter because the energy-dependent response of the unfiltered sector to electromagnetic radiation.

The calibration frequency of TLDs is highly dependent on the established readout cycle. Seven of the sites performed this calibration after each readout cycle. If the TLD readout cycle is performed quarterly or annually, it can be reasonably assumed that these dosimeters will be recalibrated after readout and before reissuance to the radiation worker.

The TLD annealing procedures varied among sites. Several procedures do not appear to be adequate to return the TLD chips to their original sensitivity. Improper annealing leaves a residual signal that will cause erroneously 
high readings when the TLD chip is reused. Oberhofer and Scharmann (1981) reported that for LiF prereadout annealing can remove any existing low temperature glow peaks $<100^{\circ} \mathrm{C}$ that are thermally unstable even at room temperature and are responsible for thermal fading. Room-temperature fading can be eliminated by a 15 -minute prereadout annealing at $100^{\circ} \mathrm{C}$ with an associated sensitivity loss of $\pm 15 \%$. Thermoluminescent output is also dependent on the holding time at the maximum readout temperature. For a fast heating rate $\left(50^{\circ} \mathrm{C} / \mathrm{sec}\right)$ and a maximum temperature of $300^{\circ} \mathrm{C}$ held for 5 seconds, $93 \%$ of the signal will be integrated. If the maximum temperature is $250^{\circ} \mathrm{C}$ with all other conditions remaining equivalent, only $90 \%$ of the signal will be measured. Therefore, a $250^{\circ} \mathrm{C}$ maximum temperature with a heating rate of $50^{\circ} \mathrm{C} / \mathrm{sec}$ over a 15 -second total readout cycle is appropriate for rapid routine evaluations. A postreadout annealing at $400^{\circ} \mathrm{C}$ retains dosimeter sensitivity over time. Raising the temperature above $400^{\circ} \mathrm{C}$ diminishes sensitivity by about $30 \%$. Therefore, a postannealing routine for 15 minutes at $400^{\circ} \mathrm{C}$ yields the same sensitivity as that held for 60 minutes at $400^{\circ} \mathrm{C}$ (Oberhofer and Scharmann 1981).

Apparently, the contractors are concerned that high temperatures will destroy the integrity of the TLD enclosures; therefore, improved dosimeter holder designs may be needed. Other techniques, such as ultravioiet flash readout, may make it possible to depopulate the deep traps without heating to very high temperatures $\left(400^{\circ} \mathrm{C}\right)$. However, these alternate methods still need to be thoroughly investigated.

\subsubsection{Photographic Film Dosimeters}

Eight of the DOE facilities responded that they utilized photographic film dosimeters. Most film dosimeters were calibrated in batch form as received from the vendor or supplier. To accurately relate the film density to the exposure delivered to the worker, the selection and calibration of the film dosimeter must be carefully controlled due to the high energy dependence of both beta and gamma components.

\subsubsection{Quality Assurance}

Nine of the 28 responding facilities indicated they had a formal quality control/quality assurance program in place for beta dosimeters. A description 
of these programs is shown in Table 11. Twenty-four facilities processed control (unexposed dosimeters) and 15 processed spiked dosimeters (dosimeters exposed to known beta dose) during dosimeter processing.

TABLE 11. Type of Formal Quality Control/Quality Assurance Program

\section{Description}

Audit of controlled and spike samples

Blind control samples

Laboratory intercomparison studies

Provided by another laboratory

Provided by vendor

None or no response
Number of

Facilities

6

4

3

1

1

g

\subsection{RADIATION DETECTION AND MEASIIREMENT INSTRUMENTS}

A wide variety of radiation measurement instruments are used at DOE facilities (Appendix B). Twenty six of the facilities reported the use of at least one instrument having a GM tube, which was generally used for personnel or area surveys. The beta window thicknesses reported for these instruments ranged from 1.4 to $30 \mathrm{mg} / \mathrm{cm}^{2}$. The typical window thickness was between 1.4 and $2.0 \mathrm{mg} / \mathrm{cm}^{2}$. Tweive of the respondents used some type of ionization instrumentation for exposure rate measurements. The beta window thicknesses for the ionization instruments ranged from 0.5 to $432 \mathrm{mg} / \mathrm{cm}^{2}$ with an average thickness of $7 \mathrm{mg} / \mathrm{cm}^{2}$.

The responses of both types of instruments are based upon the gas ionization principle. Typically, the measured exposure rate will be dependent on the energy spectra of the beta particies detected. This point needs to be considered during instrument calibration and in all field measurements.

DOE facilities identified the use of two types of GM probe configurations: a cylindrical probe geometry and a pancake type geometry. The pancake probe has a fine stainless steel protective screen covering a mica window. This covering decreases the instrument's ability to detect low-energy beta emitters such as ${ }^{14} \mathrm{C}$. 
The beta counting efficiency for all instruments ranged from a high of $100 \%$ for a liquid scintillation lab counter to a low of $2 \%$ for a rate meter with a pancake probe. The average for all reported efficiencies was approximateiy 35\%. Lower detection limits for rate meters rarged from 2 to 200 counts per minute $(\mathrm{cpm})$, with most facilities reporting a lower detection limit of between 20 and $50 \mathrm{cpm}$. Lower detection limits reported for ionization chambers were between 0.5 and $15 \mathrm{mrad} / \mathrm{h}$.

Both minimum and maximum beta detection limits should be established for each type of instrument before it is used in the field so that personnei are aware of the limitations in instrument sensitivity.

\subsubsection{Instrument Calibration Procedures}

Eighteen of the survey sites indicated that they follow the guidance of ANSI Standard N323 (1978), Radiation Protection Instrumentation Test and Calibration, in their calibration programs. This standard discusses the conditions, equipment, and techniques for the calibration as well as the degree of precision and accuracy required for alpha, beta, photon, and neutron radiation. Responses to subsequent questions indicated that some facilities may not follow all of the guidance in ANSI N323. Specific examples of this are noted in the appropriate sections of Appendix A.

As $i$ llustrated in Figure 2, 14 of the sites reported that the calibration of new detection instruments was performed by the vendor. However, 25 of the sites reported that the initial calibration was performed either in-house or by another contractor in the field office. This would tend to indicate that DOE facilities do not solely rely on the vendor's calibration before using the instruments in the field. This is especially important for instruments that will be used in different field geometry conditions from which the instrument was calibrated. An adjustment may also be necessary for instruments that will be used outside the calibration source energy range. If the instrument has been physically damaged during shipment from the vendor, recalibration at the facility would aiso be required. 


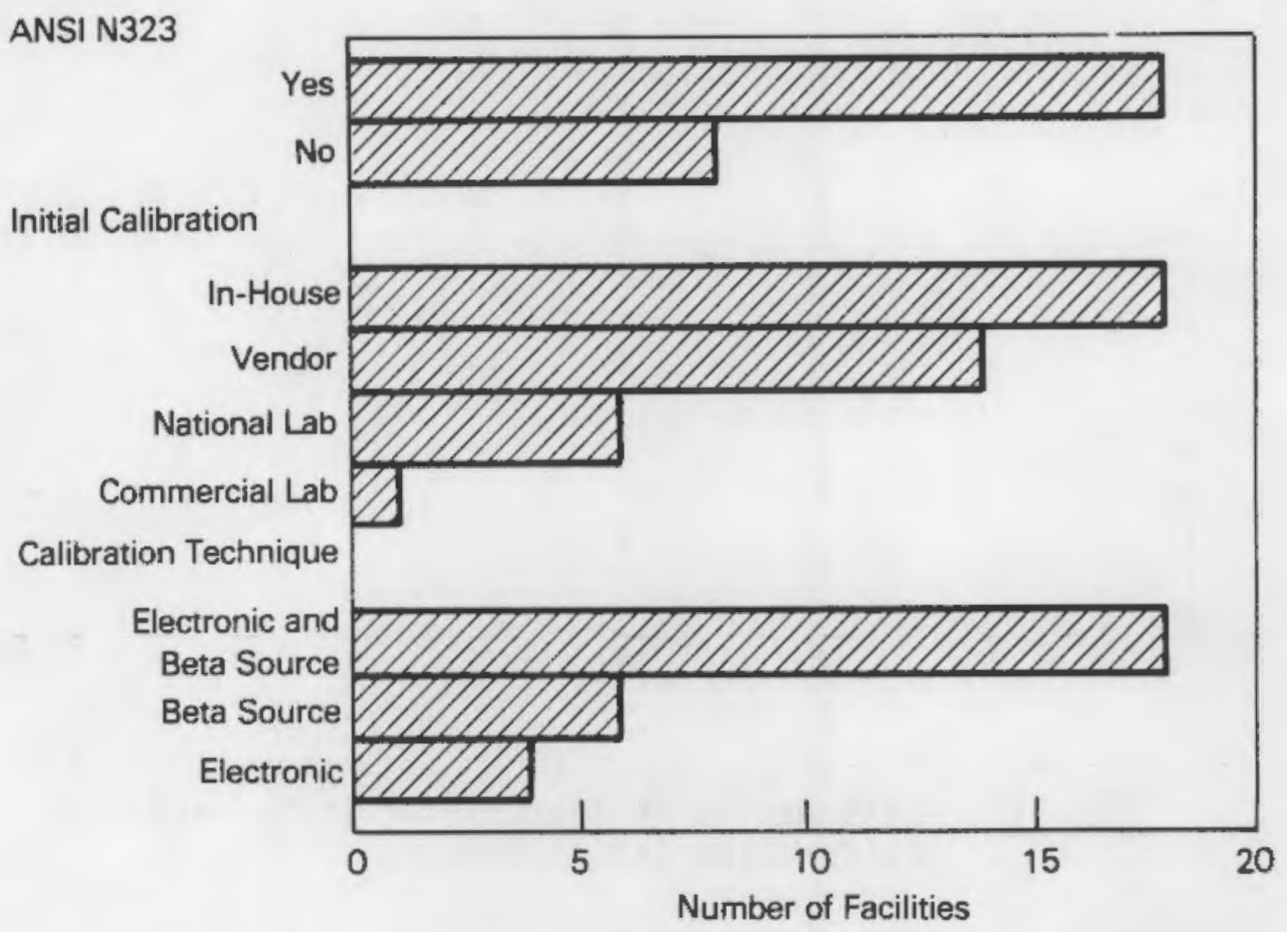

FIGURE 2. Methods Used for Beta Instrument Calibration at DOE Facilities

As shown in Table 12, a number of different sources were used at the facilities for the initial or secondary calibration of beta measurement instruments. Sources used by five of the facilities included ${ }^{90} \mathrm{Sr} /{ }^{90} \mathrm{Y},{ }^{99} \mathrm{Tc}$, and natural uranium. The beta radiation sources suggested for instrument calibration in ANSI N323 (1978) are shown in Table 13.

For beta instrument calibration, a reliable beta radiation source must be used. The characteristics of a reliable beta calibration source would include:

- The beta source energy should be similar to the beta source encountered in the field.

- The beta source should emit a minimal number of photons. 
TABLE 12. Number of Facilities Using Various Sources for Initial or Secondary Calibration of Beta Measurement Instruments According to Source Type and Geometry

\begin{tabular}{|c|c|c|c|c|c|c|c|c|c|c|}
\hline \multirow[b]{2}{*}{$\begin{array}{c}\text { Radio- } \\
\text { nuclide }\end{array}$} & \multicolumn{5}{|c|}{ Source Type } & \multicolumn{5}{|c|}{ Geometry } \\
\hline & $\begin{array}{l}\text { Number of } \\
\text { Facilities }\end{array}$ & $\begin{array}{l}\text { Nationat } \\
\text { Standard }\end{array}$ & $\begin{array}{l}\text { Secondary } \\
\text { Standard }\end{array}$ & $\begin{array}{l}\text { Laboratory } \\
\text { Standard } \\
\end{array}$ & Other & Disk & Point & Slab & Planchet & Gas \\
\hline${ }^{3} \mathrm{H}$ & 3 & 1 & 1 & 2 & 1 & & 2 & & & 3 \\
\hline${ }_{36}^{14} \mathrm{C}$ & 3 & & 1 & 1 & 1 & 2 & 1 & & & \\
\hline${ }_{63}^{36} \mathrm{Cl}$ & 4 & 1 & $\cdot 1$ & 1 & 1 & 3 & 1 & & & \\
\hline${ }_{90}^{63} \mathrm{Ni}$ & 1 & & & & 1 & & 1 & & & \\
\hline${ }_{99}^{90} \mathrm{Sr} /{ }^{90} \mathrm{Y}$ & 16 & 1 & 3 & 9 & 3 & 12 & 2 & 2 & & \\
\hline${ }_{147}^{99} \mathrm{Tc}$ & 9 & 1 & 3 & 4 & 1 & 7 & 1 & 1 & & \\
\hline${ }_{203}^{147} \mathrm{Pm}$ & 3 & 1 & & 1 & 1 & 1 & 1 & 1 & & \\
\hline${ }_{203}^{203} \mathrm{Tl}$ & 1 & & & 1 & & 1 & & & & \\
\hline $204 \mathrm{TI}$ & 3 & 1 & & 1 & 1 & 1 & 1 & & & \\
\hline${ }_{230}^{210} \mathrm{~Pb}$ & 1 & & & 1 & & & & & 1 & \\
\hline $238^{\text {Th }}$ & 4 & & 1 & 2 & 1 & 4 & & & & \\
\hline $239^{U}$ & 6 & & 1 & & & & 1 & & & \\
\hline${ }_{241} \mathrm{Pu}$ & 1 & & & 1 & & 1 & & & & \\
\hline Am & 1 & & 1 & & 1 & & & & & \\
\hline Natural U & 5 & & - & & 12 & 39 & $\overline{11}$ & 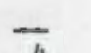 & & \\
\hline TOTAL & & 6 & 12 & 24 & 12 & 32 & 11 & 4 & 1 & 3 \\
\hline
\end{tabular}

TABLE 13. Beta Radiation Sources for Instrument Calibration (ANSI 1978)

\begin{tabular}{|c|c|c|}
\hline $\begin{array}{l}\text { Radio- } \\
\text { nuclide }\end{array}$ & Half-i ife & $\mathrm{E}_{\max }, \mathrm{MeV}$ \\
\hline $3_{\mathrm{H}}$ & $12.3 \mathrm{yr}$ & 0.0185 \\
\hline${ }^{14} \mathrm{C}$ & $5730 \mathrm{yr}$ & 0.156 \\
\hline${ }^{35} \mathrm{~s}$ & 87.2 days & 0.167 \\
\hline${ }^{45} \mathrm{Ca}$ & 164 days & 0.257 \\
\hline${ }^{185} W$ & 75 days & 0.433 \\
\hline${ }^{85} \mathrm{Kr}$ & $10.7 \mathrm{yr}$ & 0.674 \\
\hline T & $3.78 \mathrm{yr}$ & 0.763 \\
\hline $111_{\mathrm{Ag}}$ & 7.47 days & 1.03 \\
\hline $210_{B i}$ & 5.01 days & 1.16 \\
\hline${ }^{32} p$ & 14.3 days & 1.71 \\
\hline${ }^{90} \mathrm{Sr} /{ }^{90} \mathrm{Y}$ & $28.5 \mathrm{yr}$ & 2.27 \\
\hline $238_{v}$ & $4.4 \times 10^{9} \mathrm{yr}$ & 3.26 \\
\hline${ }^{42} \mathrm{~K}$ & $12.4 \mathrm{~h}$ & 3.52 \\
\hline
\end{tabular}


- The half-life of the source should be long so that frequent decay calculations are not required.

- The source should approximate an infinite planar source in that it produces a uniform radiation field.

A natural or depleted uranium slab would best meet these requirements. Radionuclides such as ${ }^{36} \mathrm{Cl},{ }^{90} \mathrm{Sr} /{ }^{90} \mathrm{Y}$, and ${ }^{99} \mathrm{Tc}$ also possess good beta radiation fields but have other limitations in their use.

With respect to source geometry, 32 calibration sources were discs, 4 were slabs, and 11 were points, and 3 were gas sources. Only one facility reported the use of a planchet. Severa? facilities specified that they did not use a beta source for instrument calibration; rather, they used some type of gamma calibration source and then applied experimentally derived ratios to determine beta activity. The methodology and validity of deriving these ratios may be questionable for several facilities.

Seventy percent of the instrumentation were reported to be calibrated by both electronic calibration and beta-source calibration. This yields a more precise representation of beta dose than does either single calibration alone. The calibration frequency for portable instrumentation was based on the instrument type and frequency of use at a particular facility. Calibration frequency ranged from daily to once every two years at one facility. The predominant frequency trend for routine calibration was evenly divided between quarterly and semiannual calibration. The ANSI N323 (1978) recommends that instruments be calibrated on a quarterly basis. There is some question, from the survey results, as to whether some respondents interpret daily performance tests as periodic calibrations.

The procedure used to determine the true beta dose rate or the activity of the source used for instrument calibrations is shown in Table 14. Most responding facilities used vendor certification for this determination.

\subsubsection{Instrument Performance Testing}

In addition to a calibration, it is essential that radiation protection instruments receive performance tests upon purchase and periodicaliy to ensure that the instrument is operating properly. Specifications followed in instrument performance testing are shown in Table 15. Most respondents appeared to test an instrument's performance at the time of purchase. At that time, 16 of 
TABLE 14. Procedure or Source Used to Determine the True Beta Dose Rate of the Source Used for Instrument Calibration

\section{Procedure/Source}

Vendor certification

Extrapolation chamber

Other instrument calibrated to a national standard

Other instrument calibrated to secondary standard

Cross-calibration with University of Michigan study

Uranium slab

In-house certification

Secondary standard

NBS-calibrated sources

None
Number of

Facilities

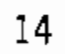

8

5

2

1

I

1

1

1

2

TABLE 15. Specifications Followed for Instrument Performance Testing

Specification

ANSI N323
Vendor specification
Purchase specification
Performance test against calitration source
Dependent on instrument usage
In-house calibration procedures
Quarterly QA audit
In-house normalization procedures
None

Number of Facilities
Using Specifications
Tnitial
Purchase Periodic

5

11

16

1

7

5

4

2

0

1

0

1

0

0

1 
the respondents test against purchase specifications, 11 against vendor specifications, and 5 against ANSI N3?3 (1978). Fewer facilities test performance on a periodic basis. Of those who do, a greater number use ANSI N323 for periodic testing as opposed to testing at the time of purchase (7 versus 5). Only 5 of the facilities periodicaliy test against vendor specifications, and 4 test against purchase specifications.

Initial and periodic performance testing is primarily performed either in-house or by a national laboratory. None of the facilities reported using a vendor for periodic testing. One facility did not provide performance testing at any time. Only one respondent indicated that a vendor was used for the initial performance test. The types of periodic checks made are shown in Table 16. Most of the respondents checked sensitivity, linearity, and reproducibility. However, very few respondents checked energy dependence, humidity, or temperature. Wone of the respondents checked pressure. A check for a response to overload conditions was done by less thar half of the responding facilities.

The types of checks against commonly unwanted instrument interferences are characteristic to both ionization and Gir instruments. They include:

- The sensitivity in an instrument assures a linear respnnse between the instrument's electronics and the radiation field encoulitered. Linearity checks assure that the readings on one scale change proportionally if the instrument changes scales.

TABLE 16. Types of Periodic Checks Performed

\begin{tabular}{lc}
\multicolumn{1}{c}{ Periodic Check } & $\begin{array}{c}\text { Number of } \\
\text { Facilities }\end{array}$ \\
\cline { 1 - 2 } Sensitivity & 25 \\
Linearity & 21 \\
Reproducibility & 20 \\
Response to overioad conditions & 13 \\
Energy dependence & 2 \\
Humidity & 1 \\
Temperature & 1 \\
Pressure & 0
\end{tabular}


- Reproducibility is important so that instruments consistently read the same values when exposed to identical radiation fields.

- The response to overload conditions is very important in field use to avoid accidental exposures. A meter should be tested to assure that it will read full scale when exposed to a radiation field twice the full-scale rate (rather than indicating zero).

- Energy dependence is important for instruments in the field. If an instrument is calibrated to a discrete beta energy and encounters another energy range in the field, the instrument response may underestimate the radiation field.

- Humidity, temperature, and pressure affect the electronic components of alt instruments. These effects may have significant impacts on the reliability of an instrument if the environmental conditions are much different from those in the calibration labcratory (Hooker et al. 1983).

\subsection{TELEPHONE SURVEY}

The original survey (Harty et al. 1986, Appendix C) did not inquire if significant numbers of workers were exposed to beta radiation and whether these workers receive a significant fraction of their dose from beta particles. To answer these critical questions, a telephone survey of the facilities participating in the original dosimetry survey was conducted. The telephone survey included the following questions:

1. How many beta dosimeters are issued?

2. How many persons receive a measurable beta dose?

3. What is the dose distribution of persons exposed to beta particies, i.e. What is the number of persons exposed, grouped by beta dose range?

4. What is the breakdown of beta versus gamma dose? Is it a sma11 fraction of gamma dose and therefore insignificant or is there a substantial beta dose component? 
After surveying eight different DOE facilities, it became apparent that these questions could not be easily answered. At the facilities included in this survey about 22,000 to 24,000 persons are monitored for exposure to betaganma radiations. Dosimetry records systems can usually separate penetrating and nonpenetrating dose, but it is extremely difficult to separate beta exposures from other nonpenetrating $x$-ray and low-energy gamma exposures. Operational health physicists can estimate the numbers of persons exposed to betas in some facilities, but it is very difficult to obtain the dose distributions.

Of the DOE facilities contacted in the telephone interview, only two could easily provide estimates of the numbers of persons exposed to beta particles. The total number of persons issued dosimeters to measure beta particles was in excess of 11,000. Of this number about 3,000 to 4,000 have a nonpenetrating dose (estimated at $7 \mathrm{mg} / \mathrm{cm}^{2}$ ) greater than that of the penetrating dose (estimated at $1000 \mathrm{mg} / \mathrm{cm}^{?}$ ). The shaliow dose equivalent or skin limit is $15 \mathrm{rem} / \mathrm{yr}$, but no persons exceeded this level and in fact were limited to 5 rem/quarter. The persons who receive the highest nonpenetrating doses are typically exposed in fields with beta/gamma dose ratios of 20:1 as estimated by survey instruments.

One facility with a very large number of workers provided some very useful information. This facility currently has 200 to 300 workers who receive significant beta exposures. The actual numbers vary because of the types of jobs performed. The high beta exposures are associated with maintenance and repair or construction work, which occurs on an infrequent basis. Significant beta exposures are associated with processing operations, where pipes internally contaminated with beta emitters are opened. Under these conditions the beta/gamma dose ratio is estimated to be 11:1 using survey instruments. This facility has studied workers with significant beta doses. In 1973 the average beta dose was $600 \mathrm{mrad} / \mathrm{yr}$ per person; this was reduced to $350 \mathrm{mrad} / \mathrm{yr}$ per person by 1981 . The operational health physicists at this facility are aware of the limitations of current beta dosimetry and are attempting to reduce the workers' exposure. One method of achieving this is to rotate workers on jobs with high beta doses to other jobs, so that no one will receive a large beta exposure. 
. 


\subsection{CONCLUSIONS AND RECOMMENOATIONS}

Section 4.1 summarizes the findings of the previous sections and concludes that beta dosimetry practices are not adequate at some $00 E$ facilities. Specific points are cited to substantiate this conclusinn. Section 4.2 recommends a cooperative program between the DOE contractors to improve and upgrade beta dosimetry practices.

\subsection{CURRENT PROBLEMS OF BETA DOSIMETRY}

The preceding sections of this report describe the dosimeters and survey instruments currently in use at DOE facilities. Some of the deficiencies of these dosimeters and instruments are also identified. Many of the current problems with beta dosimetry practices can be traced to the traditional designs of these detectors. In the past, personnel dosimeters and survey instruments were designed to measure the most prevalent type of radiation, gamma radiation. The designs were modified later for the measurement of beta rays, but in the process the modifications resulted in a compromise that is not always acceptable. The dosimeters were modified further as radiation protection standards changed.

\subsubsection{Personnel Dosimeters}

The survey revealed a broad range of personnel dosimeters currently in use. Some facilities use dosimeters which were developed in-house to meet specific requirements, while others use commercialiy available dosimetry services. The most wideiy used type of dosimeter is the TLD. Some of the facilities use very thin $\left(5-\mathrm{mg} / \mathrm{cm}^{2}\right)$ filters over the TLDs in an attempt to measure skin dose; others use much thicker filters which can only measure the most penetrating of the beta particles and give only a rough indication of beta dose.

The TLD dosimeters were designed with commercialiy available TLDs which are quite thick, usually well over $100 \mathrm{mg} / \mathrm{cm}^{2}$, to obtain good garma sensitivity. These TLDs are too thick to measure the nonpenetrating or shallow dose averaged over $5-10 \mathrm{mg} / \mathrm{cm}^{2}$ (the skin dose) accurately. As a result of heta particle attenuation with depth in the TLD, the beta dose can vary considerably over the thickness of the TLD. The dose averaged over the entire 
thickness of the TLD usuatly underestimates the shallow dose equivalent, which should be averaged over 5 to $10 \mathrm{mg} / \mathrm{cm}^{2}$ under existing regulations. The paper packets used to hold the film in photographic film dosimeters are often too thick to admit low energy beta particles.

Differentiation between beta particles and low-energy photons is usually very difficult. The filters used in many dosimeters are not compietely "tissue equivalent," and the amount of attenuation varies with energy.

All of the dosimeters currently in use require some sort of correction factor or calibration factor to be applied to compensate for the underresponse of the dosimeter to low-energy beta particles. An accurate correction can be achieved if the calibration is performed in a uniform beta field with energies comparable to those encountered in the work place. This correction may not always be possible in facilities with a wide variety of beta emitters and source configurations.

\subsubsection{Survey Instruments}

The survey revealed a wide variety of survey instruments are used in DOE facilities. The instruments include: GM counters used only to determine the presence of beta particles, ion chambers used to measure beta-gamma dose rates, gas proportional counters used for air monitoring and counting of beta emitters, and scintillation counters used to determine activity levels in beta emitting samples counted in the laboratory. Efficiencies varied from $100^{\alpha}$ for the scintillation counters to about $2 \%$ for a GM counter probe used oniy to detect the presence of beta particles. Almost all of the survey instruments are obtained from commercial vendors, al though many of the instruments are built to design specifications determined by the DOE facility.

Traditionally, survey instruments were designed with large detection volumes to give good gamma sensitivity and allow measurements of low exposure rates. Typicaliy, an absorber is placed over the thin beta window, and the beta dose rate is determined from the difference between the "open window" and "closed window" readings. Due to beta attenuation within the sensitive volume of the instrument, the ionization averaged over the whole volume is usually much lower than that averaged over a depth of 5 to $10 \mathrm{mg} / \mathrm{cm}^{2}$. This often leads to serious underestimation of the correct shallow dose equivalent or 
"skin" dose. Also, survey instruments usually have thick walls on the sides, which are required for eiectronic equilibrium to be able to measure gamma dose correctly. Ion chambers with a thin beta window on one end and thick walls on the sides have strongly anisotropic response; they cannot measure the beta rays incident from the sides in isotropic beta fieids.

\subsubsection{Correction Factors and Caljbration Factors}

Since the dosimeters and survey instruments currently in use average the dose over a thickness much greater than 5 to $10 \mathrm{mg} / \mathrm{cm}^{2}$, some sort of correction factor needs to be applied to the reading to obtain the correct shallow dose equivalent or nonpenetrating component of dose averaged over the skin depth. The use of correction factors varies widely among DOE facilities. Many of the larger national laboratories have compiled tables of correction factors to use with their instruments. Some of the facilities do not apply a correction factor, but rather rely on a single instrument calibration factor. The correction factor depends not only upon the energy of the beta, but also upon the irradiation geometry.

The problems in attempting to obtain a broad beam for calibrating survey instruments has aiready been mentioned. Both beam-flattening devices and the placement of survey instruments a greater distance from the source in order to obtain more uniformity of the beta beam over the detector volume can seriously degrade the beta energy spectrum for low-energy beta emitters. The actual beta energy spectra from practical calibration devices may not correspond to those shown in the handbooks.

Geometry effects cause inaccuracies in measurements of beta dose rates. At smail distances from the source severe gradients occur within the detector volume. These are due to inverse square behavior and from attenuation of the beta flux within the window and sensitive volume due to increased slant range. True "contact" beta dose rates cannot be accurately determined by Jarge volume detectors, such as the "Cutie Pie" ion chamber. Very large correction factors must be applied, as shown in Tabie 5 of this report.

Energy effects also cause inaccuracies in the measurement of beta dose. As mentioned previously, the windows on many dosimeters and survey instruments are thicker than $5 \mathrm{mg} / \mathrm{cm}^{2}$, so the shallow dose equivalent cannot be measured 
accurately. Some of the coverings on film dosimeters are so thick that only very high energy beta particles can reach the film to be detected.

Even if the nuclide found in the work place is the same as that used for the calibration source, the dosimeter or survey instrument calibration factor (or correction factor) may be incorrect. In the work place the betas can be significantly attenuated to lower energies by air or other shielding, such as dust or water in solutions. The average beta energy found in the work place is often lower than that of the calibration source. This lower average energy leads to the device underestimating the correct shallow dose equivalent or nonpenetrating dose equivalent. This situation was shown to exist in a number of DOE facilities where beta spectra were actually measured in the work place (Rathbun, Swinth, and Haggard 1986). Furthermore, there were actual work situations measured where the beta dose rate was significantly higher than the gamma dose rate. For example, the beta:gamma dose rate ratios varied from $8: 1$ to $160: 1$. These measurements were made in a variety of facilities, including chemical separations facilities (measurements on process samples in the analytical Taboratories and waste streams), fuel fabrication facilities (measurements on fuel pellets), a uranium metal working and foundry facility, and a plutonium production reactor. Admittedly, these locations were specificaliy selected to have high beta dose rates for ease of measurements. However, they do show that significant beta dose rates can be measured at a wide variety of

DOE facilities. Simitar beta dose problems were noted in European facilities (Regulla 1986).

\subsubsection{Conclusions}

From the information given in Section 3.4, the following conclusion can be made: operational health physicists at several OOE sites are aware of the limitations of beta dosimetry and are doing something to reduce workers' exposure to beta radiation.

However, in view of the known inaccuracies of both personnel dosimeters and portable survey instruments, there is a possibility that significant beta doses are not being measured at some DOE facilities. This conclusion is based upon the following points. 
- All beta personnel dosimeters and survey instruments underestimate the true shallow dose equivalent because the detector volumes do not average the beta dose over $5-$ to $10-\mathrm{mg} / \mathrm{cm}^{2}$ thicknesses. Therefore, some sort of calibration factor must be applied to the reading to correct for the underresponse.

- Few facilities have good beta calibration sources; i.e. intense beta sources with broad beams that can uniformly irradiate the large detector volumes of existing survey instruments. Smali disk or point sources do not necessarily simulate work place exposure situations. Calibration sources frequently do not have direct traceability to the NBS.

- Large correction factors must frequently be applied to account for differences in geometry between the survey instrument calibration and work piace exposure situations. In extreme cases with point sources this correction factor can be as high as 100 (Hooker et al. 1983).

- Actual field measurements in work locations with beta spectrometers and multicomponent dosimeter/spectrometers have confirmed the existence of high beta-to-gamma ratios at a wide variety of DOE facilities (Rathbun et al. 1986). Furthermore, the measured spectra are usually degraded to lower energies, where even larger correction factors are required to correct for the underresponse of existing beta dosimeters. This fact is usualiy not known or appreciated by many operational heal th physicists.

- The survey revealed that significant numbers of workers (about $35 \%$ ) are limited by their exposure to beta-emitting nuclides.

- Present methods of measuring and record-keeping for nompenetrating or shallow dose equivalent do not permit one to easily determine the population dose (man-rem) from beta dose. Measurement and recording methods are not uniform among DOE contractors. 


\subsection{RECOMMENDATIONS TO IMPROVE BETA DOSIMETRY}

A solution to the inaccuracies of existing beta dosimetry is to develop and implement improved personnel dosimeters and survey instruments. Recently, there has been considerable progress in the development of new personne? dosimeters which attempt to measure the beta dose averaged over 5- to $10-\mathrm{mg} / \mathrm{cm}^{2}$ thicknesses to measure the skin dose or shallow dose equivalent. Some of these developments have been funded by DOE, while others have been developed in Europe. Some of these new dosimeters are commerciatiy available and can be incorporated into existing dosimetry systems.

A new type of TLD, commonly referred to as a "band-aid" dosimeter, has been recently introduced (Dutt et a 1. 1984). The active element is a TL powder in a plastic matrix, which is 10 mm $\times 6$ man and is approximately $5 \mathrm{mg} / \mathrm{cm}^{2}$ thick. The rightproof cover is about $6 \mathrm{mg} / \mathrm{cm}^{2}$ thick. This dosimeter is commercially available in the United Kingdom. The dosimeter is flexible enough to be wrapped around the finger for extremity dosimetry. Unfortunately, the dosimeter is not very sensitive because of the small amount of TL phosphor in the sensitive volume.

As part of the DOE sponsored program, Kansas State University under contract with the Pacific Northwest Laboratory has developed a beta dosimeter composed of a thin LiF $\left(13-\mathrm{mg} / \mathrm{cm}^{2}\right)$ TLO wafer glued to a graphite backing. The TLD wafer measures the approximate skin dose while the nearly tissueequivalent graphite supports the fragile wafers. The device is about the same size as standard commercial chips, 1/8 in. $\times 1 / 8$ in. (Swinth 1985).

Thermoluminescent dosimeters can be loaded with an opaque substance, such as graphite, which blocks the light from deep within the TLD. Although it is the same size as standard TLD chips, the dosimeter emits light only from the surface (Gesell et at. 1979).

Dosimeters can also be made by diffusing boron into LiF chips to a depth of 1 to $2 \mathrm{mg} / \mathrm{cm}^{2}$. The boron-loaded TL material gives off light at a higher temperature $\left(290^{\circ} \mathrm{C}\right)$ on the surface than the bulk of the TL material $\left(185^{\circ} \mathrm{C}\right)$. Thus, it is easy to separate the dose from the surface of the TLD from the dose of the entire volume of the TLD by reading it out at a higher temperature (Gesell et al. 1979). 
The above beta dosimeters contain little TL material and lack sensitivity compared to conventional TLD chips. As part of the existing DOE program to improve beta dosimetry, a recently developed laser readout technique promises to improve the sensitivity of thin film TLDs (Braunlich et al. 1984). In this dosimeter the TL powder is mixed in a polymer matrix which strongly absorbs infrared but transmits visible light emitted by the $\mathrm{IL}$ phosphor. The very thin TL film is supported on glass or other suitable substrate and illuminated with an infrared carbon dioxide laser. The TL material is heated and read out in milliseconds. Because of the much shorter readout time, the signalto-noise ratio is greatly improved, and the TLD is quite sensitive to beta radiation.

Another recent development that may lead to increased sensitivity in beta dosimeters is the introduction of a practical, thermaliy stimulated exoelectron (TSEE) dosimeter. Previous TSEE dosimeters were not uniform in response and were subject to environmental interference. An improved dosimeter material composed of a mixture of graphite and beryllium oxide may soon be available. A paper on this dosimeter was given at the U.S. Department of Energy-European Radiation Dosimetry Group (DOE-EURADOS) workshop "Dosimetry of Beta Particles and Low Energy X-Rays," held on October 7-9, 1985 in Saclay, France; an article will be published by $M$. Petel in the journal Radiation Protection Dosimetry.

There have also been some recent advances in survey instrumentation. Several commercial firms have started manufacturing so called "smart" instruments based upon microcomputer technology. These instruments can determine the dose rates from a wide variety of different probes using counting efficiency data stored in computer memory. Perhaps a new probe could be adapted to accurately measure beta dose averaged over a detector thickness of 5 to $10 \mathrm{mg} / \mathrm{cm}^{2}$. Over 30 years ago a "pancake" ion chamber was designed which overcame many of the problems of current survey instruments (Roesch and Donaldson 1955). This instrument had a very thin, sensitive volume to reduce the effect of of variations in the beta flux with depth in the sensitive volume. This instrument has never been manufactured commercially. There has also been some work recently using thin scintillator films to measure the beta dose more accurately. Perhaps a new probe could be built and adapted to work 
with one of the "smart" instruments. The new probe idea would be much less expensive and perhaps more commercially viable than developing a new, expensive beta instrument.

Since implementation of any new personnel dosimetry system or adoption of new types of more accurate beta survey instrumentation will take some time, several measures that could be implemented in the near future to increase the accuracy of beta dosimetry. The first measure would be to characterize the performance of beta instruments which are currentiy in use. A second measure would be a series of workshops for DOE contractors to promote discussion of current beta measurement problems and how to deal with them. Some of the DOE facilities have improved operational health physics prograns which could be of benefit to other DOE sites. A third measure would be a manual of good practices for beta detection and measurement, with emphasis on calibration techniques, field measurement techniques and quality assurance practices, to help standardize and improve beta dosimetry practices at all DOE sites.

There has been some concern recently that the existing standards for beta dosimetry do not provide enough guidance. New standards are being promulgated by Committee 80 of the NCRP, that may be available in a few years to provide better guidance. Also, with the adoption of improved beta dosimeters, it may be prudent to establish a more uniform system of reporting and recording beta doses to workers. 


\section{REFERENCES}

American National Standards Institute (ANSI). 1978. American National Standard Radiation Protection Instrumentation Test and Calibration. ANSI N323, Institute of Electrical and Electronics Engineers, Inc., New York, New York.

American National Standards Institute (ANSI). 1983. Draft Criteria for Testing Personnel Dosimetry Performance. ANSI N13.11, New York, New York.

Berger, M. J. 1971. "Distribution of Absorbed Dose Around Point Sources of Electrons and Beta Particles in Water and Other Media." Medical Internal Radiation Dose Committee (MIRD) Pamphlet 7, Journal of Nuclear Medicine, Supplement No. 5, Vol. 12, p. 5-24.

Baunlich, P., W. Tetzlaff, J. Gasiot and S. C. Jones. 1984. "Development of a Laser-Heated TLD Reader." In Proceedings of the International Beta Dosimetry Symposium, pp. 293-305. NUREG/CP-0050, Washington, D.C.

Chabot, G. E., Jr., M. A. Jimenez and K. W. Skrable. 1978. "Personne? Dosimetry in the U.S.A." Health Physics Journal, 34:311-321.

Commission of European Communities (CEC). 1980. Third information seminar on the Radiation Protection Dosimeter Intercomparison Programme, Radiological Protection-24, Grenoble.

Cross, W. G., H. Ing, N. O. Freedman and J. Mainville. 1982. Tables of BetaRay Dose Distributions in Water, Air and Other Media. AECL-7617, Atomic Energy of Canada Limited, Chalk River, Ontario, Canada.

Dutt, J. C., K. Chongkitivitya, R. J. Pattison, J. C. Stewart and A. McWhan. 1984. "The Performance of a New Extremity and Skin Dosimeter." Rad. Prot. Dosimetry 6:257-266.

Federal Radiation CounciT (FRC). 1960. "Radiation Protection Guidance For Federal Agencies." 25 Federal Register 4402 (May 13, 1960).

Federal Radiation Protection Guidance for 0ccupational Exposure, 46 Fed. Reg. 7836 (January 23, 1981). (Cited in the text as the Federa) Radiation Protection Guidance for Occupational Exposure of January 1981).

Fitzgerald, J. J., G. L. Brownell and F. J. Mahoney. 1967. Mathematical Theory of Radiation Dosimetry. Gordon and Breach Science PubTishers, Inc., New York.

Gesel1, T. F, D. E. Jones, V. P. Gupta, F. L. Kalbreitzer and J. P. Cusimano. 1979. "A Personnel Dosimetry Method for Reducing Energy Dependence." ID0-12090, Radiological and Environmental Sciences Laboratory, U.S. Department of Energy, Idaho Falis, Idaho. 
Harty, R., W. D. Reece, J. A. Maclellan, J. M. Selby and E. J. Vatiario. 1986. Extremity Dosimetry at U.S. Department of Energy Facilities. PNL-5831, Pacific Northwest Laboratory, Richland, Washington.

Hooker, C. D., D. E. Hadlock, W. N. Herrington and R. L. Gilchrist. 1983. Interim Calibration and Field Use Guidance for Beta Portable Survey Instruments. PNL-4378, Pacific Northwest Laboratory, Richland, Washington.

InternationaT Commission on Radiological Protection (ICRP). 1966. Recommendations of the Internationa! Commission on Radiological Protection. Publication 9, Pergamon Press, Oxford, Great Britain.

International Commission on Radiological Protection (ICRP). 1977. Recommendations of the International Conmission on Radiological Protection. Publication 26, Pergamon Press, New York.

International Commission on Radiologica! Protection (ICRP). 1982. Genera? Principles of Monitoring for Radiation Protection of Workers. PlibTication 35, Pergamon Press, New York.

International Commission on Radiation Units and Measurements (ICRU). 1972. Measurement of Low-LeveT Radioactivity. Publication 22, Washington, D.C.

International Organization for Standardization (ISO). 1983. Reference Beta Radiations for Calibrating Dosimeters and Doseratemeters and for Determining Their Response as a Function of Beta Radiation Energy. Oraft ISO/DIS 6980, PubTication 22, 1972 .

Kathren, R. L. 1975. "Standard Sources for Health Physics Instrument Calibration." Health Physics Journal, 29:143-153.

Klotz, A. S. 1984. "The Ideal Beta Personnel Dosimeter." In Proceeding of the International Beta Dosimetry Symposium, Washington, D. C.

Knoll, G. F. 1979. Radiation Detection and Measurement. John Wiley and Sons, New York.

Loevinger, R., E. M. Japha and G. L. Browne11. 1956. Radiation Dosimetry. Academic Press, Inc., New York.

National Commission on Radiation Protection (NCRP). 1971. Basic Radiation Protection Criteria. NCRP 39, Washington, D.C.

Oberhofer, M., and A. Scharmann. 1981. Applied Thermoluminescence Dosimetry. Adam Hilger, Ltd., Bristol.

Porta1, G. 1984. "Requirements of Instruments in Radiological Protection," Radiation Protection Dosimetry, 9:189-194. 
Rathbun, L. A., G. W. R. Endres, R. A. Fox, P. L. Roberson and R. I. Scherpelz. 1983. Beta Particle Measurement and Dosimetry Requirements at NRC-Licensed Facilitjes. NUREG/CR-3544. Nuclear Regulatory Commission, Washington, D.C.

Rathbun, L. A., K. L. Swinth and D. L. Haggard. 1986. Beta Measurements at Department of Energy Facilities. PNL-5847, Pacific Northwest Laboratory, Richiand, Wastington.

Reece, W. D., R. Harty, L. W. Brackenbush and P. L. Roberson. 1985. Extremity Monitoring: Considerations for Use, Dosimeter Placement and Evaluation. PNL-5509 (NUREG/CR-4297), Pacific Northwest Laboratory, Richland, Washington.

Roberson, P. L., K. L. Holbrook, R. C. Yoder, R. A. Fox, R. T. Hadley, B. T. Hogan and C. D. Hooker. 1983. Performance Comparison of Selected Personne T Dosimetry Systems in Use at Department of Energy Facilities. PNL-3983, Pacific Northwest Laboratory, Richland, Washington.

Roesch, W. C., and G. E. Donaldson. 1955. "Portable Instruments for Beta-Ray Dosimetry." In Proceedings of the International Conference on the Peaceful Uses of Atomic Energy, Pp. 172-175. United llations, New York.

Scherpeiz, R. I., G. W. R. Endres and L. A. Rathbun. 1983. The Use of MultiElement Beta Dosimeters for Measuring Dose Rate in the TM -2 Containment Building. PNL-4714, Pacific Northwest Laboratory, Richland, Washington.

Simons, G. G., J. D. Gale and J. F. Higginbotham. 1983. Research Report nOE Beta Dosimetry Upgrade Program. "Graphite-Backed Thin TLD Beta Particle Dosimeters." Kansas State University, Manhattan, Kansas.

Swinth, K. L. 1985. "DOE Reta Measurement Evaluation and Upgrade Program." The Health Physics Society Newsletter 13(5):4-5.

Traub, R. J., W. D. Reece, R. I. Scherpelz and L. A. Sigalla. 1986. Dose Calculation for Contamination of the Skin, Including the Computer Code VARSKIN. PNL-5610 (NUREG/CR-4418), Pacific Northwest Laboratory, Richland, Washington.

U. S. Department of Energy (DOE). 1981. "Standards and Requirements for Radiation Protection." DOE Order 5480.11, Chapter XI, Washington, D.C. 


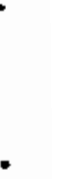




\section{APPENDIX A}

BETA MEASUREMENT QUESTIONNAIRE AND RESPONSES 


\section{BETA MEASUREMENT QUESTIONNAIRE AND RESPONSES}

\section{SECTION I - BACKGROUND INFORMATION}

A. Please provide the following information:

Name of person completing questionnaire

Title

Department

Contractor

Site or Facility

Address

B. Do you wish to receive a copy of the results of this questionnaire?

(Respondents: 28 of 28 )

Yes

No

0

C. Are you interested in attending a DOE workshop on beta dosimetry/measurement probiems? (Respondents: 28 of 28)

Yes

25

No

3

D. Do you currently have a beta-monitoring program? (Respondents: 28 of 28)

Yes

No ${ }^{(a)}$

26

Currently being established

1

(a) Facility $F$ reported that they monitor total betamgamma activity and are not generally concerned with beta-gamma discrimination. 
E. What are the beta-emitting radionuclides of concern at your facility? Do any of these nuclides imit radiation protection program requirements? (Respondents: 26 of 28 )

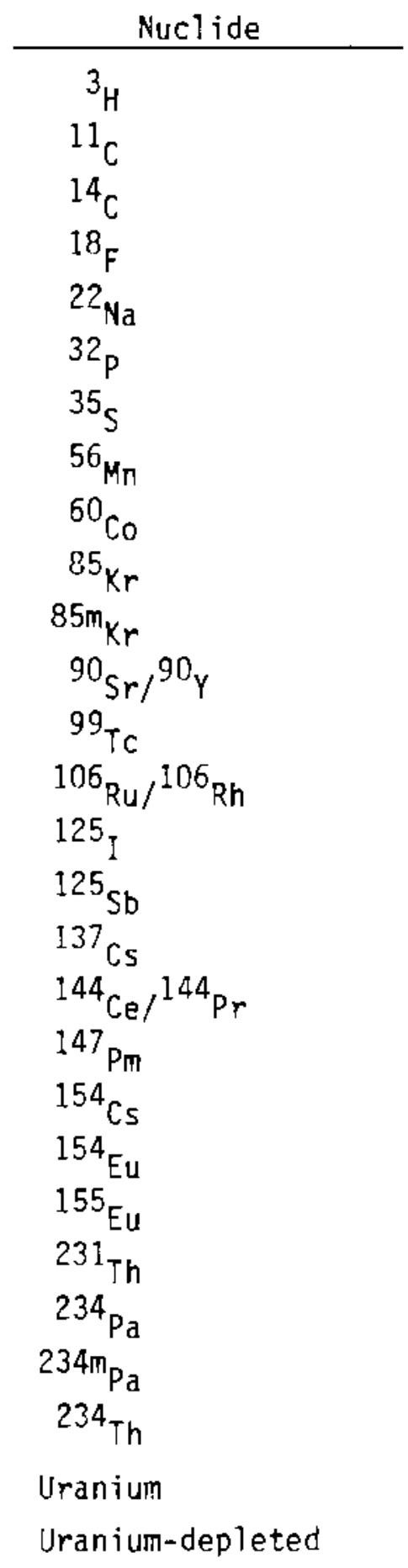

\begin{tabular}{|c|c|c|}
\hline \multicolumn{3}{|c|}{ Number of Facilities } \\
\hline $\begin{array}{l}\text { Total } \\
\text { Reporting } \\
\text { Nuclide }\end{array}$ & $\begin{array}{c}\text { Nuclide } \\
\text { Limits } \\
\text { Requirements } \\
\end{array}$ & $\begin{array}{l}\text { NucT ide Does } \\
\text { Not Limit } \\
\text { Requirements } \\
\end{array}$ \\
\hline 9 & 1 & 7 \\
\hline 2 & 1 & 1 \\
\hline 5 & 1 & 3 \\
\hline 1 & & 1 \\
\hline 1 & & 1 \\
\hline 3 & & 3 \\
\hline 1 & & 1 \\
\hline 1 & & 1 \\
\hline 3 & & 2 \\
\hline 2 & 1 & 1 \\
\hline 1 & & 1 \\
\hline 9 & 3 & 5 \\
\hline 5 & 1 & 3 \\
\hline 2 & & 2 \\
\hline$i$ & & 1 \\
\hline 1 & & 1 \\
\hline 5 & 1 & 3 \\
\hline 2 & & 2 \\
\hline 3 & & 3 \\
\hline 1 & & 1 \\
\hline 1 & & 1 \\
\hline 1 & & 1 \\
\hline 1 & & \\
\hline 3 & 1 & 1 \\
\hline 4 & 3 & 1 \\
\hline 5 & 2 & 2 \\
\hline 1 & & 1 \\
\hline 1 & & \\
\hline
\end{tabular}


E. (contd)

Nuclide

Uranium-natura 1

Uranium-enriched

$238 \mathrm{v}$

$241_{\mathrm{Pu}}$

Mixed Activation Products

Mixed Fission Products

Others

Thorium

Radioiodines

Xenons
Number of Facilities

\begin{tabular}{ccc}
\hline Total & Nuclide & Nuclide Does \\
$\begin{array}{c}\text { Reporting } \\
\text { Nuclide }\end{array}$ & Limits & Not Limit \\
Requirements & Requirements \\
\hline
\end{tabular}

2

2

2

1

1

4 (a)

$3^{(a)}$

1

1

1

(a) Facility $N$ stated that these nuclides sometimes limit extremity exposure but rarely limit skin doses.

F. How is the absorbed beta component determined in mixed radiation field measurements? (Respondents: 26 of 28)

Window open/window closed method 25

Not determined (a) 2

Other (b) 1

(a) Facilities $F$ and $W$ determine on $T y$ total beta-ganma activity.

(b) Facility $P$ reported using an instrument (developed in-house) that directly reads the absorbed dose at 5 to $10 \mathrm{mg} / \mathrm{cm}^{2}$. 
SECTION II - PERSONNEL DOSIMETERS FOR BETA DOSE ASSESSMENT

A. What types of dosimeters are used at your facility for monitoring beta? (Respondents: 28 of 28 )

TLDs

Film

None ${ }^{(a)}$

(a) Facility I determines personnel dose from tritium with a urinaiysis program.

B. Where are the personnel dosimeters processed? (Respondents: 25 of 28)

In-house 14

National laboratory 4

Vendor 4

Commercial laboratory 3

C. General Dosimeter Calibration Information.

1. What standards or guides are used in the calibration of personne? dosimeters? (Respondents: 23 of 28)

ANSI N13.11, Draft Criteria for Testing Personnel 9

Dosimetry Performance ${ }^{(a)}$

Other $(b, c, d)$

None used

7

(a) Facilities $P$ and $Q$ utilize ANSI N13.11 for gamma and $x$-ray dosimeters only.

(b) Facilities $D, H$, and $V$ use in-house calibration procedures.

(c) Facilities K, L, M, and $N$ use historical field measurements as a guide for calibration.

(d) Facility $R$ standardizes accelerator dosimeters against a LET spectrometer. 
2. What beta radiation sources are used to calibrate personnel dosimeters? (Respondents: 23 of 28 )

\begin{tabular}{|c|c|}
\hline Facility & Beta Radia \\
\hline$B, J, T, V$ & Depleted uranium slabs \\
\hline$D, K, L, M, N, P, Q, W$ & Uranium siab \\
\hline$R, X$ & Natural uranium \\
\hline $\begin{array}{l}C, E, F, H, R, S, \\
U, V, Z, B B\end{array}$ & ${ }^{90} \mathrm{Sr} /{ }^{90} \mathrm{Y}$ \\
\hline$A A$ & None \\
\hline$A, I, 0, Y, C C$ & No response \\
\hline
\end{tabular}

D. For TLD badges, please provide the following information:

1. Is a commercially designed TLD system used at your facility? (Respondents: 21 of 28 )

No

$Y_{e s}^{(a, b, c, d)}$
8
(a) Facilities $B, C, D, U$, and $V$ use a Harshaw-designed system.
(b) Facility $\mathrm{H}$ is planning to use an Eberline-designed system.
(c) Facilities $R$ and $S$ are using an Eberline-designed system.
(d) Facility $Z$ uses a Panasonic reader system.

2. Please provide the following information (position, material, radiation type measured) about your TLDs: (Respondents: 20 of 28)

\begin{tabular}{|c|c|c|c|}
\hline Facility & TLD Position & TLD Material & $\begin{array}{l}\text { Radiation Type Measurec } \\
\text { (beta, gamma, neutron) }\end{array}$ \\
\hline B & $\begin{array}{l}1 \\
2 \\
3 \\
4\end{array}$ & $\begin{array}{l}\text { TLD }-700 \\
\text { TLD-700 } \\
\text { TLD-600 } \\
\text { TLD-700 }\end{array}$ & $\begin{array}{l}\text { beta, gamma } \\
\text { beta, gamma } \\
\text { gamma, neutron } \\
\text { gamma }\end{array}$ \\
\hline c & $\begin{array}{l}1 \\
2 \\
3 \\
4\end{array}$ & $\begin{array}{l}\text { TLD-700 } \\
\text { TLD-700 } \\
\text { TLD-700 } \\
\text { TLD-600 }\end{array}$ & $\begin{array}{l}\text { gamma } \\
\text { beta, soft } x \text {-rays } \\
\text { beta, soft } x \text {-rays } \\
\text { neutron (albedo) }\end{array}$ \\
\hline
\end{tabular}


2. (contd)

\begin{tabular}{|c|c|c|c|}
\hline $\begin{array}{l}\text { (contd) } \\
\text { Facility }\end{array}$ & TLD Position & TLD Material & $\begin{array}{l}\text { Radiation Type Measured } \\
\text { (beta, gamma, neutron) }\end{array}$ \\
\hline D & 1 & LiF & beta, ganmma \\
\hline H & $\begin{array}{l}1 \\
2 \\
3\end{array}$ & $\begin{array}{l}\text { TLD-700 } \\
\text { TLD-700 } \\
\text { TLD-700 }\end{array}$ & $\begin{array}{l}\text { beta } \\
\text { gamma } \\
\text { gamma }\end{array}$ \\
\hline J & 1 & TLD-700 & beta, gamma \\
\hline$K, L, M, N$ & $\begin{array}{l}1 \\
2 \\
3 \\
4 \\
5\end{array}$ & $\begin{array}{l}\text { TLD }-700 \\
\text { TLD-700 } \\
\text { TLD-600 } \\
\text { TLD-600 } \\
\text { TLD-700 }\end{array}$ & $\begin{array}{l}\text { beta, gamma } \\
\text { beta, gamma } \\
\text { gamma, neutron } \\
\text { gamma, neutron } \\
\text { gamma }\end{array}$ \\
\hline$P, Q$ & $\begin{array}{l}1 \\
2\end{array}$ & $\begin{array}{l}\text { TLD-700 } \\
\text { TLD-700 }\end{array}$ & $\begin{array}{l}\text { beta, gamma, x-ray } \\
\text { gamma, x-ray }\end{array}$ \\
\hline$R$ & $\begin{array}{l}1 \\
2\end{array}$ & $\begin{array}{l}\text { TLD-700 } \\
\text { TLD-600 }\end{array}$ & $\begin{array}{l}\text { beta, gamma } \\
\text { gamma, neutron }\end{array}$ \\
\hline$s$ & 1 & TLD-100 & beta, gamma \\
\hline$T$ & $\frac{1}{2}$ & $\begin{array}{l}\text { TLD-700 } \\
\text { TLD-600 }\end{array}$ & $\begin{array}{l}\text { beta, gamma } \\
\text { gammia, neutron }\end{array}$ \\
\hline v & $\begin{array}{l}1 \\
2 \\
3 \\
4\end{array}$ & $\begin{array}{l}\text { TLD-600 } \\
\text { TLD-700 } \\
\text { TLD-600 } \\
\text { TLD-700 }\end{array}$ & $\begin{array}{l}\text { gamma, neutron } \\
\text { beta, gamma } \\
\text { gamma, neutron } \\
\text { gamma }\end{array}$ \\
\hline$v$ & $\frac{1}{2}$ & $\begin{array}{l}\text { TLD }-700 \\
\text { TLD-700 }\end{array}$ & $\begin{array}{l}\text { gamma } \\
\text { beta, gamma }\end{array}$ \\
\hline$w$ & Finger & LiF & beta, ganmla \\
\hline z & $\begin{array}{l}1 \\
2 \\
3 \\
4\end{array}$ & $\begin{array}{l}\mathrm{Li}_{2} \mathrm{~B}_{4} \mathrm{O}_{7}: \mathrm{Cu} \\
\mathrm{Li}_{2} \mathrm{~B}_{4} \mathrm{O}_{7}: \mathrm{Cu} \\
\mathrm{CaSO}_{4}: \mathrm{Tm} \\
\mathrm{CaSO}_{4}: \mathrm{Tm}\end{array}$ & $\begin{array}{l}\text { beta, gamma } \\
\text { beta, ganma } \\
\text { x-ray } \\
\text { gamma }\end{array}$ \\
\hline$A A$ & $\begin{array}{l}1 \\
2 \\
3 \\
4\end{array}$ & $\begin{array}{l}\text { TLD-700 } \\
\text { TLD-700 } \\
\text { TLD-100 } \\
\text { TLD-600 }\end{array}$ & $\begin{array}{l}\text { beta, gamma } \\
\text { beta, ganma } \\
\text { gamma, neutron } \\
\text { neutron }\end{array}$ \\
\hline$B B$ & Finger & TLD-100 & beta, garma \\
\hline
\end{tabular}


3. What thickness of absorber material is used in the dosimeters? (Respondents: 21 of 28)

\begin{tabular}{|c|c|c|c|c|}
\hline Facility & $\begin{array}{l}\text { Chip/Film } \\
\text { Position } \\
\end{array}$ & $\begin{array}{l}\text { Absorber } \\
\text { Material }\end{array}$ & $\begin{array}{c}\text { Density } \\
\text { Thickness, } \mathrm{mg} / \mathrm{cm}^{2} \\
\end{array}$ & $\begin{array}{l}\text { Radiation } \\
\text { Type Assessed }\end{array}$ \\
\hline \multirow[t]{4}{*}{ B } & 1 & $\begin{array}{l}\text { Identification } \\
\text { badge/teflon }\end{array}$ & 98 & beta, gamma \\
\hline & 2 & $\begin{array}{l}\text { Identification } \\
\text { badge/teflon insert }\end{array}$ & 182 & beta, gasma \\
\hline & 3 & $\begin{array}{l}\text { Identification } \\
\text { badge/teflon/Cd-AL/ } \\
\text { plastic insert }\end{array}$ & 1192 & $\begin{array}{l}\text { neutron, } \\
\text { gamma }\end{array}$ \\
\hline & 4 & $\begin{array}{l}\text { Identification } \\
\text { badge/teflon/AL/ } \\
\text { plastic insert }\end{array}$ & 451 & gamma \\
\hline \multirow[t]{4}{*}{$\mathrm{C}$} & 1 & $\begin{array}{l}\text { Cycolac plastic } \\
\text { and copper }\end{array}$ & 1000 & $\begin{array}{l}\text { gammiz at } 1 \\
\mathrm{~cm} \text { in tissue }\end{array}$ \\
\hline & 2 & Cycotac plastic & 290 & $\begin{array}{l}\text { beta, soft } \\
x-\text { rays }\end{array}$ \\
\hline & 3 & Cycolac plastic & $\approx 250$ & $\begin{array}{l}\text { beta, soft } \\
\text { rays }\end{array}$ \\
\hline & 4 & Cycolac plastic & $\approx 250$ & $\begin{array}{l}\text { neutron } \\
\text { (a) bedo) }\end{array}$ \\
\hline \multirow[t]{2}{*}{ D } & 1 & Aluminum & 428.6 & $\begin{array}{l}\text { beta, gamme } \\
\text { x-ray }\end{array}$ \\
\hline & 2 & None & NA & Beta \\
\hline$E$ & 1 & Film wrapper & 25 & $\begin{array}{l}\text { beta, Iow } \\
\text { energy } x- \\
\text { ray }\end{array}$ \\
\hline \multirow[t]{4}{*}{$\mathrm{F}$} & 1 & None & 25 & beta, gamma \\
\hline & 2 & Plastic & 325 & gamma \\
\hline & 3 & Aluminum & 375 & gamma \\
\hline & 4 & Lead and tin & 1660 & gamma \\
\hline $\mathrm{H}$ & 1 & Mylar & 12 & $\begin{array}{l}\text { beta, soft } \\
x-\text { ray }\end{array}$ \\
\hline
\end{tabular}




\begin{tabular}{|c|c|c|c|c|}
\hline $\begin{array}{l}\text { 3. (contd) } \\
\text { Facjlity }\end{array}$ & $\begin{array}{c}\text { Chip/Film } \\
\text { Position } \\
\end{array}$ & $\begin{array}{l}\text { Absorber } \\
\text { Material }\end{array}$ & $\begin{array}{c}\text { Density } \\
\text { Thickness, } \mathrm{mg} / \mathrm{cm}^{2} \\
\end{array}$ & $\begin{array}{c}\text { Radiation } \\
\text { Iype Assessed }\end{array}$ \\
\hline & 2 & Aluminum & 285 & gamma, $x$-ray \\
\hline & 3 & Aluminum & 285 & gamma, $x$-ray \\
\hline J & 1 & Plastic & 15 & beta, gamma \\
\hline \multirow{5}{*}{$K, L, M, N$} & 1 & Plastic & 95 & $\operatorname{beta}^{(\mathrm{a})}$ \\
\hline & 2 & Plastic, aluminum & 390 & $\operatorname{beta}^{(b)}$ \\
\hline & 3 & Plastic, tin & 925 & $\begin{array}{l}\text { neutron, } \\
\text { gamına }\end{array}$ \\
\hline & 4 & $\begin{array}{l}\text { Plastic, cadmium, } \\
\text { tin }\end{array}$ & 1010 & $\begin{array}{l}\text { neutron, } \\
\text { garmila }\end{array}$ \\
\hline & 5 & Plastic, tin & 925 & Gamma \\
\hline \multirow[t]{2}{*}{$P$} & 1 & Mylar & 5 & $\begin{array}{l}\text { beta, gamma, } \\
x-\text { ray }\end{array}$ \\
\hline & 2 & Aluminum, plastic & $\sim 700$ & gamma, $x$-ray \\
\hline \multirow[t]{2}{*}{ n } & 1 & Mylar & 5 & $\begin{array}{l}\text { beta, gamma, } \\
\text { x-ray }\end{array}$ \\
\hline & 2 & Aluminum, plastic & $\approx 700$ & gamma, $x-r a y$ \\
\hline \multirow[t]{3}{*}{$R$} & 1 & Paper & 26.2 & $\begin{array}{l}\text { beta (and } \\
\text { gamma in } \\
\text { free air) }\end{array}$ \\
\hline & 2 & Aluminum & 439 & $\begin{array}{l}\text { beta, gamma, } \\
\text { x-ray }\end{array}$ \\
\hline & 3 & Cadmium & 945 & $\begin{array}{l}\text { gamma (hard } \\
x-r a y)\end{array}$ \\
\hline \multirow[t]{2}{*}{ S } & 1 & My]ar & 10 & $\begin{array}{l}\text { beta and } \\
\text { gamma }\end{array}$ \\
\hline & 2 & Aluminum & 285 & gamma \\
\hline \multirow[t]{2}{*}{$T$} & 1 & Mylar, plastic & 5 & beta \\
\hline & 2 & Plastic, brass & 131 & garma \\
\hline
\end{tabular}




\begin{tabular}{|c|c|c|c|c|}
\hline $\begin{array}{l}\text { 3. (contd) } \\
\text { Facility }\end{array}$ & $\begin{array}{l}\text { Chip/Film } \\
\text { Position } \\
\end{array}$ & $\begin{array}{l}\text { Absorber } \\
\text { Material }\end{array}$ & $\begin{array}{c}\text { Density } \\
\text { Thickness, } \mathrm{mg} / \mathrm{cm}^{2}\end{array}$ & $\begin{array}{c}\text { Radiation } \\
\text { Type Assessed } \\
\end{array}$ \\
\hline & 3 & Plastic & 110 & gamma, x-ray \\
\hline \multirow[t]{4}{*}{$\mathrm{U}$} & 1 & Aluminum, plastic & 610 & neutron, gamma \\
\hline & 2 & Paper & 7 & beta, gamma \\
\hline & 3 & Aluminum, plastic & 610 & neutron, gamma \\
\hline & 4 & Aluminum, plastic & 610 & gamma \\
\hline \multirow[t]{2}{*}{ V } & 1 & Plastic & 50 & beta, gamma \\
\hline & 2 & Aluminum & 720 & gamma \\
\hline \multirow[t]{4}{*}{$x$} & 1 & $\begin{array}{l}\text { Paper, pTastic } \\
\text { mylar, air }\end{array}$ & 0.53 & $\begin{array}{l}\text { Nonpene- } \\
\text { trating }\end{array}$ \\
\hline & 2 & ATuminum & 131 & $x-$ ray \\
\hline & 3 & Silver & 133 & $x-\operatorname{ray}$ \\
\hline & 4 & Cadmiurn & 865 & $\begin{array}{l}\text { penetrating } \\
\text { component }\end{array}$ \\
\hline \multirow[t]{4}{*}{ Z } & 1 & Plastic & 42 & beta, gamma \\
\hline & 2 & Plastic & 99 & beta, gamma \\
\hline & 3 & Plastic, paper & 228 & $x-r a y$ \\
\hline & 4 & $\begin{array}{l}\text { Lead, plastic, } \\
\text { paper }\end{array}$ & 828 & gamma \\
\hline \multirow[t]{4}{*}{ AA } & 1 & Window & 60 & beta, garma \\
\hline & 2 & Plastic & 160 & beta, gamma \\
\hline & 3 & Aluminum & 430 & gamma \\
\hline & 4 & Cadmium & & $\begin{array}{l}\text { neutron, } \\
\text { gammina }\end{array}$ \\
\hline
\end{tabular}

(a) Response calibrated to $7 \mathrm{mg} / \mathrm{cm}^{2}$ for specified beta spectrum. (b) Energy greater than about $1.0 \mathrm{MeV}$. 
4. What are the annealing procedures used for your TLDs? (Please include temperatures if known.) (Respondents: 19 of 28)

\section{Facility}

B

C, D

$\mathrm{H}$

$\mathrm{J}$

$X, L, M, N$

$P, Q, X$

R

T

U

V

2

AA

$B B$

\section{Procedure}

For chips that can not be zeroed after normal readout cycle $1 \mathrm{~h}$ annealing at $100^{\circ} \mathrm{C}$

17 h annealing at $80^{\circ} \mathrm{C}$

$1.5 \mathrm{~h}$ at $415^{\circ} \mathrm{C} ; 16 \mathrm{~h}$ at $85^{\circ} \mathrm{C}$

I h h at $400^{\circ} \mathrm{C} ; 2 \mathrm{~h}$ at $100^{\circ} \mathrm{C}$

10 min at $100^{\circ} \mathrm{C}$ preanneal

Preread anneal 30 min at $80^{\circ} \mathrm{C}$

Preissue anneal $16 \mathrm{~h}$ at $80^{\circ} \mathrm{C}$

$1.5 \mathrm{~h}$ at $415^{\circ} \mathrm{C}$

$16 \mathrm{~h}$ at $85^{\circ} \mathrm{C}$

I h at $400^{\circ} \mathrm{C}$

24 h at $80^{\circ} \mathrm{C}$

I h at $400^{\circ} \mathrm{C}$

Preissue $15 \mathrm{sec}$ at $270^{\circ} \mathrm{C}$

$150^{\circ}$ preheat $25 \mathrm{sec}$ at $300^{\circ} \mathrm{C}$ 17 h at $80^{\circ} \mathrm{C}$

Heated for 750 msec to 1 A fiash

30 min at $400^{\circ} \mathrm{C}$

cool 3 min

$2 \mathrm{~h}$ at $100^{\circ}$

$4 \mathrm{~h}$ at $400^{\circ} \mathrm{C}$

preanneal 15 min at $115^{\circ} \mathrm{C}$

5. How are the TLDs calibrated? (Respondents: 19 of 28)

In a given batch of TLDs 11

Individual dosimeter chips 7

Individual dosimeters 1

Other
7

3 
6. How often are the TLDS recalibrated? (Respondents: 16 of 28 )

\begin{tabular}{ll} 
Facility & \multicolumn{1}{c}{ Calibration Frequency } \\
B & $\begin{array}{l}\text { Each chip is checked every readout cycle; system calibra- } \\
\text { tion curve is checked yearly }\end{array}$ \\
C,P & Monthly \\
$\mathrm{H}$ & Annually \\
$\mathrm{K}, \mathrm{L}, \mathrm{M}, \mathrm{N}$ & $\begin{array}{l}\text { Calibration dosimeters processed during every readout } \\
\text { cycle along with audit dosimeters }\end{array}$ \\
$\mathrm{R}$ & After annealing cycle \\
$\mathrm{S}$ & Each batch \\
$\mathrm{T}$ & Infrequentiy \\
$\mathrm{U}, \mathrm{Z}$ & Quarteriy \\
$\mathrm{V}$ & Initially upon setup, thereafter, as controls indicate \\
$\mathrm{Z}$ & need
\end{tabular}

E. For film badges, please provide the following information.

1. What $f i l m$ badges are used at your facility for personnel dosimetry? (Respondents: 7 of 28)

Facility Fijm Badges

$\begin{array}{ll}E & \text { R.S. Landauer } \\ F & \text { Neutrak I, NTA } \\ R & \text { Facility's in-houl } \\ X & \begin{array}{l}\text { Facility's badge } \\ \text { badge }\end{array} \\ \text { AA } & \text { Eastman Type B } \\ \text { BB } & \text { Kodak Type 3 }\end{array}$


2. How are film dosimeters calibrated? (Respondents: 6 of 28)

By each batch received from the supplier 6

By a sample from within a batch from the supplier 3 Other ${ }^{(a)}$

(a) Facility B performs a quarterly calibration.

F. Quality Assurance.

1. Is a formal Quality Control/Quality Assurance Program in place for your beta dosimeters? (Respondents: 24 of 28)

\begin{tabular}{|c|c|c|}
\hline Facility & Response & Description \\
\hline$B$ & Yes & $\begin{array}{l}\text { Spiked dosimeters and intercomparison } \\
\text { studies }\end{array}$ \\
\hline 0 & Yes & Provided by a national Taboratory \\
\hline$E$ & Yes & Provided by vendor \\
\hline $\mathrm{J}$ & Yes & Blind sample analysis \\
\hline$K, L, M, N$ & Yes & Audit of controlled and spike samples \\
\hline$P, Q, V$ & Yes & Blind control samples \\
\hline $\mathrm{R}, \mathrm{X}$ & Yes & Laboratory intercomparison studies \\
\hline U & Yes & Analysis of known and spiked samples \\
\hline $\begin{array}{l}B, C, F, H \\
S, T, Z, \\
A A, B B\end{array}$ & No & \\
\hline
\end{tabular}

2. During dosimeter processing, are control (unexposed) dosimeters processed? (Respondents: 25 of 28 )

Yes 24

No 1

3. During dosimetry processing, are spiked dosimeters (i.e., dosimeters exposed to known beta dose) processed? (Respondents: 25 of 28)

Yes

No
14

11 
SECTION III - INSTRUMENT CALIBRATION

A. Is the guidance of ANSI Standard N323-1978, Radiation Protection Instrumentation and Calibration, followed in your instrument calibration program? (Respondents: 27 of 28 )

Yes $(a)$

No (b)

Unknown
18

8

1

(a) Facility 0 follows ANSI $N 323$ for gamma sources on $7 y$; calibration to beta sources is not currently done.

(b) Facility I stated that ANSI N323 is not applicable for instrumentation that monitors tritium.

B. How are these instruments initially calibrated? (Respondents: 27 of 28) (a)

In-house

18

Vendor

14

National Lab

Commercial Lab

Unknown (a) Several facilities identified more than one initial calibration
source.

C. What type of instrument calibrations are performed? (Respondents: 26 of $28)^{(a)}$

Electronic calibration and beta source calibration 18

Beta source only 6

Electronic calibration only 3

other $(b, c, d)$

(a) Several facilities identified that more than one type of calibration

(b) Facility A directiy calibrates their instruments to a ${ }^{226} \mathrm{Ra}$ gamma standard.

(c) Facility $Z$ provides only gamma source calibrations.

(d) Facility $U$ also uses electronic and gamma calibrations. 
D. How frequently are periodic calibrations performed on these instruments? (Respondents: 27 of 28)

\begin{tabular}{|c|c|c|}
\hline Facility & Type of Instrument & $\begin{array}{ll}\text { A-Annually } & \text { M-Monthly } \\
\text { S-Semiannually } & \text { Q-Quarterly } \\
\text { D-Daily } & 0 \text {-0ther } \\
\text { Calibration Frequency }\end{array}$ \\
\hline A & AlT & C \\
\hline B & $\begin{array}{l}\text { Rate meter w/pancake, Sampson, GM rate } \\
\text { meter } \\
\text { Cutie pie }\end{array}$ & $\mathrm{S}$ \\
\hline C & $\begin{array}{l}\text { Eberline E-530, Eberline HFM-3A, Ludlum/ } \\
\text { pancake } \\
\text { NMC PC-5, Tennelec L8-5100 }\end{array}$ & $0^{(a)}$ \\
\hline$D$ & $\begin{array}{l}\text { Al1 } \\
\text { Radiographic facility instruments }\end{array}$ & S \\
\hline$E$ & $470 \mathrm{~A}, 490$ & $\mathrm{q}$ \\
\hline $\mathrm{F}$ & $\begin{array}{l}\text { Frisker } \\
\text { ETron }\end{array}$ & $\begin{array}{l}S \\
Q\end{array}$ \\
\hline$H$ & $\begin{array}{l}\text { Condenser R-meter } \\
\text { Others }\end{array}$ & $\begin{array}{l}0(2 \mathrm{yr}) \\
\mathrm{S}\end{array}$ \\
\hline I & $\begin{array}{l}\text { Kanne, Overhoff } \\
\text { T-446 } \\
\text { PC-4, PC-5, ]iquid scintiliation }\end{array}$ & $\begin{array}{l}0 \\
0 \\
0\end{array}$ \\
\hline 了 & $\begin{array}{l}\text { Portabie survey meters, tritium fixed, } \\
\text { tritium portable }\end{array}$ & Q \\
\hline K & $\begin{array}{l}\text { E } 140 \text { B } \\
\text { HP260 probe } \\
\text { R0-3B } \\
\text { GN }-4000\end{array}$ & $\begin{array}{l}0(5 w k) \\
S \\
0 \\
M\end{array}(2 w k)$ \\
\hline$L$ & $\begin{array}{l}E-140 \\
H P-260\end{array}$ & $\begin{array}{l}0(5 w k) \\
S\end{array}$ \\
\hline$M$ & $\begin{array}{l}H P-260 \\
E-140 B\end{array}$ & $\begin{array}{l}S \\
0(5 \mathrm{wk})\end{array}$ \\
\hline N & $\begin{array}{l}H P-260 \\
E-140 B\end{array}$ & $\begin{array}{l}S \\
0(5 w k)\end{array}$ \\
\hline 0 & HP portables & $s$ \\
\hline
\end{tabular}




\begin{tabular}{|c|c|c|}
\hline Facility & Type of Instrument & $\begin{array}{ll}\text { A-Annualiy } & \text { M-Monthly } \\
\text { S-Seniannually } & \text { Q-Quarterly } \\
\text { D-Daily } & \text { O-Other } \\
\text { Calibration Frequency } \\
\end{array}$ \\
\hline$P$ & $\begin{array}{l}\text { RM } 14 \\
\text { LAD }\end{array}$ & $\begin{array}{l}S \\
S\end{array}$ \\
\hline$Q$ & No response & \\
\hline $\mathrm{R}$ & $\begin{array}{l}\text { FC2 } \\
\text { Portables } \\
\text { Fixed Laboratory }\end{array}$ & $\begin{array}{l}M \\
A \\
D\end{array}$ \\
\hline $\mathrm{S}$ & $\begin{array}{l}\text { E-530, HP- } 260 \\
\text { AMS-3A } \\
\text { LudTum proportional }\end{array}$ & A \\
\hline$T$ & $\begin{array}{l}\text { Pancake } \\
\text { Tube }\end{array}$ & $\begin{array}{l}M \\
W\end{array}$ \\
\hline $\mathrm{U}$ & $\begin{array}{l}\text { Portable survey } \\
\text { Hand \& foot, swipe, air monitor, tritium }\end{array}$ & Q \\
\hline V & $\begin{array}{l}\text { Victoreen CDV-700, Victoreen COV-493, } \\
\text { Ludlum 2P, Ludlum } 3\end{array}$ & $0(8 w k)$ \\
\hline W & $\begin{array}{l}\text { LudTum, PC-4 } \\
\text { MS-2 }\end{array}$ & $\begin{array}{l}S \\
0\end{array}$ \\
\hline$x$ & $\begin{array}{l}\text { Pac } 4 G \\
\text { Fixed scaler } \\
\text { End window GM, ion chambers }\end{array}$ & $\begin{array}{l}S \\
0 \\
S\end{array}$ \\
\hline$Y$ & Lab counters/hand \& foot & S \\
\hline Z & ATI & $s^{(c)}$ \\
\hline$A A$ & $\begin{array}{l}\text { Portable survey, air monitors } \\
\text { Friskers, hand \& foot } \\
\text { Smear counters }\end{array}$ & $\begin{array}{l}Q \\
M\end{array}$ \\
\hline$B B$ & $\begin{array}{l}\text { Eberl ine E-140, Ludlum Model-101 } \\
\text { Eberl ine MS-2 and MS-3, Tennelec LB-5100 }\end{array}$ & $\begin{array}{l}M \\
D\end{array}$ \\
\hline $\mathrm{CC}$ & $\begin{array}{l}5100 \\
\text { PC } 4 / 5\end{array}$ & $0(b)$ \\
\hline
\end{tabular}

(a) Portable, low range instruments are calibrated on a 6-month frequency to ${ }^{60} \mathrm{Co}$ and $226 \mathrm{~Pa}$. Friskers are response checked week $7 y$. Portable beta instruments are response checked prior to use.

(b) When required for use.

(c) Semiannully and/or whenever serviced, whichever is shorter. 
E. What types of beta sources (source types) are available for instrument calibrations? (Respondents: 27 of 28)

1. Source Type - Number

National Standard of Geometry Initial Secondary

Radionuclides

$\begin{array}{cccc}\text { Facilities } & \text { (slab, point, etc.) } & \text { Calibration } & \text { Calibration } \\ 1 & \text { Slab } & x & x \\ 1 & \text { Slab } & x & x \\ 1 & \text { Slab } & x & x \\ 1 & \text { Point } & x & x \\ 1 & \text { Point } & x & x \\ 1 & \text { Point } & x & x\end{array}$

(a) Facility 0 indicated this is only for gamma calibration.

(b) Facility A calibrates their instruments to radium ganma rays; field readings are expressed as equivalent gamma readings. This is related to surface beta activity by experimentally determined conversion factors.

2. Source Type - Number

Secondary Standard Radionuclides

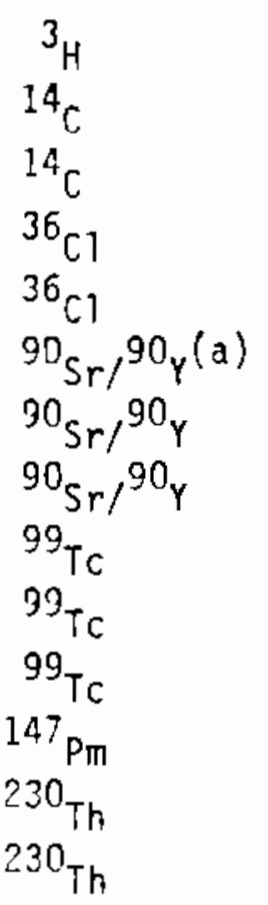

of
Facilities Facilities

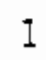

1

1

1

1

1

2

1

1

3

1

1

1

I

\begin{tabular}{ccc}
$\begin{array}{c}\text { Geometry } \\
\text { (siab, point, etc.) }\end{array}$ & $\begin{array}{c}\text { Initial } \\
\text { Calibration }\end{array}$ & $\begin{array}{c}\text { Secondary } \\
\text { Calibration }\end{array}$ \\
\cline { 1 - 2 } Gas & $x$ & $x$ \\
Disk & $x$ & $x$ \\
Disk & $x$ & \\
Disk & $x$ & $x$ \\
Disk & $x$ & \\
Disk & & $x$ \\
Disk & $x$ & \\
Oisk & $x$ & \\
Disk & $x$ & \\
Disk & $x$ & $x$ \\
Disk & & $x$ \\
Disk & $x$ & \\
Disk & $x$ & \\
Disk & $x$ &
\end{tabular}


2. (contd)

Secondary Standard Radionuclides $238 \mathrm{U}$

Natural uranium

Variety

other
Number

of Geometry Initial Secondary

Facilities (slab, point, etc.) Calibration Calibration

STab

$x$

$x$

1

Slab

Point $x$

$x$

(a) Facility $C$ uses this standard only for gas flow proportional counters.

(b) Facility $U$ stated that they have a variety of point sources used for initial calibration.

3. Source Type -

Laboratory

Standard

Radionuctides

$$
3 \mathrm{H}
$$

${ }^{14} \mathrm{C}$

${ }^{36} \mathrm{Cl}$

${ }^{90} \mathrm{Sr} /{ }^{90} \mathrm{Y}$

${ }^{90} \mathrm{Sr} /{ }^{90} \mathrm{Y}(\mathrm{a})$

${ }^{90} \mathrm{Sr} /{ }^{90} \mathrm{Y}$

${ }^{90} \mathrm{Sr} /{ }^{90} \mathrm{Y}$

${ }^{90} \mathrm{Sr} /{ }^{90_{Y}}$

${ }^{90} \mathrm{Sr}_{\mathrm{r} /}{ }^{90} \mathrm{Y}$

${ }^{99} \mathrm{TC}$

${ }^{99} \mathrm{TC}$

${ }^{147} \mathrm{Pm}$

${ }^{203} \mathrm{TI}$

${ }^{204} \mathrm{Tl}$

${ }^{204} \mathrm{Th}$

${ }^{208} \mathrm{~T} 1$

$210_{B i}$

$210 \mathrm{~Pb}$

${ }^{230} \mathrm{Th}$

$238_{\mathrm{U}}$ (b)
Number

of

Facilities

2

1

2

3

2

2

3

1

1

3

2

1

1

1

1

1

1

1

2

2
Geometry

(slab, point, etc.)

Gas

Point

Disk

Disk

Disk

Disk

Point

Point

Slab

Disk

Point

Slab

Disk

Disk

Slab

Disk

Disk

Planchet

Disk

Slab
Initial

Calibration

$x$

$x$

$x$

$\mathrm{X}$

$x$

$x$

$x$

$x$

$x$

$x$

$x$

$x$

$x$

$x$

$x$

A. 17 
3. (contd)

Laboratory

Standard

Radionuclides

Number

$238_{\mathrm{U}}$

${ }^{239} \mathrm{Pu}$

$241_{\mathrm{Am}}$

of

Facilities

Natural uranium

1

1

1

Geometry

Initiat

Secondary

Natura] uranium

3

(slab, point, etc.)

Calibration

Calibration

STab

Disk

Disk

Slab

I

Point

$\begin{array}{ll}x & x \\ x & x \\ x & x \\ & x\end{array}$

(a) Facility $M$ does not consider this to be a true calibratinn, but rather a field check.

(b) The betas from ${ }^{238} \mathrm{U}$ and depleted uranium are from the daughter ${ }^{234} \mathrm{Th}$, which has a halfalife of 24 days and is in equilibrium within a few months of separation of the uranium.

4. Source Type - Number
(Other)
of
Geometry Initial Secondary

Radionuclides

Facilities

${ }^{3} \mathrm{H}$

${ }^{3} \mathrm{H}$

$63 \mathrm{Ni}$

${ }^{90} \mathrm{Sr} /{ }^{90} \mathrm{Y}$

${ }^{90} \mathrm{Sr} / 90_{Y}$

$238^{\mathrm{U}}$

$238_{U}$

Aged $238_{U}$

Others $(a, b, c, d, e)$

1

1

1

(slab, point, etc.) Calibration Calibration

1

I

2

1

1
Point

Gas

Point

Disk

Point

Slab

Point

Slab $x$

$x$

$x$

$x$

$x$

$x \quad x$

$x$ $x$
$x$

(a) Facility $E$ stated that they do not perform beta source calibrations. Calibrations are done with gammas from beta-gamma ${ }^{137} \mathrm{Cs}, 60 \mathrm{Co}$, and ${ }^{22} \mathrm{Na}$.

(b) Facility $D$ instruments are calibrated to a ${ }^{60} C_{0}$ and ${ }^{137} C_{s}$ point source. Instruments are source checked on slab U-metal. Correction factors of three (surface) and two (distance) are applied to beta instrument readings to estimate beta dose rates (skin) using a gamma calibrated instrument.

(c) Facility $P$ has a $x$-ray machine for additional low-energy electron sources.

(d) Facility $Y$ presently does not use beta sources for instrument calibration. Instruments are calibrated with ${ }^{226} \mathrm{Ra}$ and assumed to respond equally to betas and gammas.

(e) Facility 5 aTso has a New England NucTear (NEN) beta source set. 
F. How is the true beta dose rate (or activity of the sources used for instrument calibrations) determined? (Respondents: 27 of 28)

Vendor certification

Extrapolation chamber

Other instrument calibrated to a national standard 5

Other instrument calibrated to a secondary standard 2

other $(a, b, c, d, e, f, g)$
(a) Facility $C$ indicated that their true source activity is determined by a cross calibration to a University of Michigan study.
(b) Facility $E$ specified that the source activity is related to a $233 \mathrm{mrad} / \mathrm{h}$ natural uranium slab.
(c) Facility $F$ does not determine beta source activity for calibrations.
(d) Facility I stated that this is done by in-house verification.
(e) Facilities 0 and $Z$ do not currently calibrate with beta sources.
(f) Facjlity $V$ determines source activity from a secondary standard.
(g) Facility $W$ also uses NBS calibrated sources.

G. How are radiation instruments performance-tested?

1. What specifications are followed for instrument performance testing at the time of purchase? (Respondents: 25 of 28)

Purchase Specifications $\quad 16$

Vendor Specifications $\quad 11$

ANSI N323 5

Other $(\mathrm{a}, \mathrm{b}, \mathrm{c})$

None 1

(a) Facility $\mathrm{E}$ performance tests against a ${ }^{137} \mathrm{Cs}$ calibration source and a uranium slab.

(b) Facility W uses standards and check sources.

(c) Faciitity 0 provides initial performance testing for only gamma instruments. 
2. What specifications are followed for instrument performance testing on a periodic basis? (Respondents: 26 of 28)

ANSI N323 7

Vendor Specifications 5

Purchase Specifications 4

Other $(a, b, c, d, e, f, g, h, i) \quad g$

None 5

(a) Facility $E$ performance tests against a ${ }^{137}$ Cs calibration source and a uranium slab.

(b) Facility 0 provides periodic performance testing for only gama instruments.

(c) Facility $\mathrm{P}$ does periodic performance testing based on the instrument usage.

(d) Facility $V$ does periodic performance testing based on in-house normalization procedures.

(e) Facility $X$ provides periodic performance testing based on an instrument's field use and reliability.

(f) Facility $Y$ uses in-house calibration procedures.

(g) Facility BB has a quarterly QA audit for performance testing of beta instruments.

(h) Facility W uses check sources and standards.

(i) Facility L uses in-house calibration procedures.

H. Who performs initial performance testing? (Respondents: 27 of 28)

In-house

17

National Laboratory

8

Vendor

No performance testing

1. Who performs periodic performance testing? (Respondents: 26 of 28 )

In-house 17

Nationa 1 Laboratory

8

Vendor

No performance testing 
J. Are periodic checks made on the following: (Respondents: 27 of 28)

$\begin{array}{lcc}\text { Sensitivity } & 25 & 2 \\ \text { Linearity } & 21 & 5^{(a)} \\ \text { Reproducibility } & 20 & 6^{(a)} \\ \text { Response to overioad conditions } & 13 & 13^{(a)} \\ \text { Energy dependence } & 2 & 25 \\ \text { Humidity effects } & 1^{(b)} & 26 \\ \text { Temperature effects } & 1^{(c)} & 26 \\ \text { Pressure effects } & & 27\end{array}$

(a) Facility $Y$ indicated this is unknown.

(b) Facility CC indicated that humidity (from 5\% to 50\%) is checked.

(c) Facility BB stated that the temperature range (from -20 to $50^{\circ} \mathrm{C}$ ) is checked.

K. How of ten are check sources used? (Respondents: 27 of 28)

Prior to each instrument use 20

Daily 6

Week Ty 1

Not used 1

Other $(\mathrm{a}, \mathrm{b}, \mathrm{c})$
(a) Facilities $F$ and I use check sources semiannually.
(b) Facility $\mathrm{CC}$ uses check sources before and after, and sometimes during, instrument use.
(c) Facilities BB and U use check sources on some instruments at the time they are issued for use. 
a

.

\section{.}


APPENDIX B

PORTABLE, LABORATORY, AND PERSONNEL CONTAMINATION INSTRUMENTS ROUTINELY USED TO DETECT AND/OR MEASURE BETA ACTIVITY AT DOE FACILITIES 


\section{APPENDIX B}

PORTABLE, LABORATORY, AND PERSONNEL CONTAMINATION INSTRUMENTS ROUTI NELY USED TO DETECT AND/OR MEASURE BETA ACTIVITY AT DOE FACILITIES

\begin{tabular}{|c|c|c|c|c|c|c|c|c|}
\hline $\begin{array}{l}\text { Instrument } \\
\text { Type }\end{array}$ & $\begin{array}{l}\text { Manuf acturer } \\
\text { and Number }\end{array}$ & Primary Use & $\begin{array}{c}\text { Beta } \\
\text { Window } \\
\text { Material }\end{array}$ & $\begin{array}{l}\text { Window } \\
\text { Thickness } \\
\mathrm{mg} / \mathrm{cm}^{2} \\
\end{array}$ & $\begin{array}{l}\text { Detector } \\
\text { Fill Gas } \\
\end{array}$ & $\begin{array}{c}\text { Lower } \\
\text { Detection } \\
\text { Limit } \\
\end{array}$ & $\begin{array}{c}\text { Beta } \\
\text { Counting } \\
\text { Efficiency } \\
\end{array}$ & Alarm Set Point \\
\hline \multicolumn{9}{|l|}{ Facility A } \\
\hline $\begin{array}{l}\text { Rate meter } \\
\text { with pancake }\end{array}$ & $\begin{array}{l}\text { Everline E-120 } \\
\text { with HP-260 } \\
\text { probe }\end{array}$ & $\begin{array}{l}\text { Personnel and } \\
\text { area surveys }\end{array}$ & Mica & 1.4 to 2 & $N A(a)$ & $\begin{array}{l}11,000{ }^{d p m} / \\
100 \mathrm{~cm}^{d}\end{array}$ & $458-238 v$ & NA \\
\hline $\begin{array}{l}\text { Rate meter } \\
\text { with pancake }\end{array}$ & $\begin{array}{l}\text { Ludium Model } 2 \\
\text { with 44-9 } \\
\text { probe }\end{array}$ & $\begin{array}{l}\text { Personnel and } \\
\text { area surveys }\end{array}$ & Mica & $i .5$ to 2 & NA & $\begin{array}{l}18,000_{2} \mathrm{dpm} / \\
100 \mathrm{~cm}^{2}\end{array}$ & $35-{ }^{99} \mathrm{Tc}$ & NA \\
\hline $\begin{array}{l}\text { Cutie pie mith } \\
\text { paper chamber }\end{array}$ & In-house & Area surveys & Paper & 212 & $A i r$ & $\sim 2 \mathrm{mrad} / \mathrm{h}$ & NA & NA \\
\hline \multicolumn{9}{|l|}{ Focility $B$} \\
\hline $\begin{array}{l}\text { Rate meter } \\
\text { with pancake }\end{array}$ & $\begin{array}{l}\text { Ludl um Mode i } \\
1244-9 \text { probe }\end{array}$ & $N R^{(b)}$ & Mica & 2 & NA & $20 \mathrm{cpm}$ & $20 \%$ & NA \\
\hline $\begin{array}{l}\text { GM rate } \\
\text { meter }\end{array}$ & $\begin{array}{l}\text { Eberline E-140 } \\
\text { HP- } 270 \text { probe }\end{array}$ & NR & $\begin{array}{l}\text { Stainless } \\
\text { steel }\end{array}$ & 30 & Xeon & $40 \mathrm{cpm}$ & $15 \%$ & NA \\
\hline Cutie pie & $\begin{array}{l}\text { Technical } \\
\text { Associates } \\
\text { CP-44 }\end{array}$ & NR & Mylar & 432 & $\mathrm{Air}$ & $1 \mathrm{mR} / \mathrm{h}$ & NR & NA \\
\hline Internal & $\begin{array}{l}\text { Nucl ear Data } \\
\text { Proportional }\end{array}$ & $N R$ & $P C-5$ & NR & $P-10$ & $1 \mathrm{cpm}$ & 508 & NA \\
\hline Handcounters & Eberline & $\mathrm{NK}$ & Mylar & 2 & $P-10$ & NR & $20 \%$ & $2000 \mathrm{cpm}$ \\
\hline
\end{tabular}

(a) $N A=$ not applicable.

(b) $N R=$ no response. 


\begin{tabular}{|c|c|c|c|c|c|c|c|c|c|}
\hline & $\begin{array}{c}\text { Instrument } \\
\text { Type } \\
\end{array}$ & $\begin{array}{c}\text { Manuf acturer } \\
\text { and Number }\end{array}$ & Primary Use & $\begin{array}{c}\text { Beta } \\
\text { Window } \\
\text { Material } \\
\end{array}$ & $\begin{array}{l}\text { Wi ndow } \\
\text { Thi ckness } \\
\text { mg/cm² }\end{array}$ & $\begin{array}{l}\text { Detector } \\
\text { Fyll Gas }\end{array}$ & $\begin{array}{l}\text { Lower } \\
\text { Detection } \\
\text { Limit }\end{array}$ & $\begin{array}{c}\text { Beta } \\
\text { Counting } \\
\text { Efficiency } \\
\end{array}$ & Al arn \\
\hline & \multicolumn{9}{|l|}{ Facility $C$} \\
\hline & $\begin{array}{l}\text { Hand and foot } \\
\text { monitor }\end{array}$ & $\begin{array}{l}\text { Eberline HFM- } \\
3 \mathrm{~A}\end{array}$ & $\begin{array}{l}\text { Personnel } \\
\text { Frisker }\end{array}$ & Mi ca & $\begin{array}{l}1.4 \text { to } \\
2.0\end{array}$ & Air & $25 \mathrm{cpm}$ & v58 & 500 \\
\hline & $\begin{array}{l}\text { Rate meter } \\
\text { with pancake }\end{array}$ & Ludl un 14 & $\begin{array}{l}{ }^{14} \mathrm{C} \text { Monitor- } \\
\text { ing; central } \\
\text { beta monitor- } \\
\text { ing }\end{array}$ & $\mathrm{Hica}$ & $\begin{array}{l}1.4 \text { to } \\
2.0\end{array}$ & Air & $75 \mathrm{cpm}$ & 2450 & NA \\
\hline & $\begin{array}{l}\text { Rate meter } \\
\text { with pancake }\end{array}$ & $\begin{array}{l}\text { Ludlum } 14 \text { with } \\
\text { Eberitine HP- } \\
201 T \text { probe }\end{array}$ & $\begin{array}{l}\text { Low-l evel } \\
\text { beta surveys }\end{array}$ & Mica & $\begin{array}{l}1.4 \text { to } \\
2.0\end{array}$ & Air & $75 \mathrm{cpm}$ & N58 & NA \\
\hline & $\begin{array}{l}G M \text { rate } \\
\text { meter }\end{array}$ & $\begin{array}{l}\text { Eberline with } \\
\text { HP-177C probe }\end{array}$ & $\begin{array}{l}\text { Ceneral moni- } \\
\text { toring }\end{array}$ & Metal & 30 & Halogen & $240 \mathrm{cpm}$ & 0728 & NA \\
\hline & $\begin{array}{l}\text { Rate meter } \\
\text { with end win- } \\
\text { dow CM }\end{array}$ & $\begin{array}{l}\text { Ludl um with } \\
44-4 \text { probe }\end{array}$ & $\begin{array}{l}{ }^{14} \mathrm{C} \text { surveys; } \\
\mathrm{x} \text {-ray leakage }\end{array}$ & Mica & $\begin{array}{l}1.4 \text { to } \\
2.0\end{array}$ & Air & $50 \mathrm{cpm}$ & 2450 & NA \\
\hline \multirow[t]{7}{*}{ iv } & $\begin{array}{l}\text { CM rate } \\
\text { meter }\end{array}$ & $\begin{array}{l}\text { Ludlum } 14 \text { with } \\
\text { 44-6 probe }\end{array}$ & $\begin{array}{l}\text { General moni- } \\
\text { toring }\end{array}$ & Metal & 30 & Halogen & $40 \mathrm{cpm}$ & 2128 & NA \\
\hline & $\begin{array}{l}\text { Rate meter } \\
\text { with pancake }\end{array}$ & $\begin{array}{l}\text { Ludlum } 14 \text { with } \\
44-9 \text { probe }\end{array}$ & ${ }^{14} \mathrm{C}$ monitoring & Mica & $\begin{array}{l}1.4 \text { to } \\
2.0\end{array}$ & Air & $75 \mathrm{cpm}$ & 2450 & NA \\
\hline & $\begin{array}{l}\text { Gas fiow pro- } \\
\text { portional }\end{array}$ & $\begin{array}{l}\text { Nuclear } \\
\text { Measurements } \\
\text { Corporation } \\
\text { PC-5 }\end{array}$ & $\begin{array}{l}\text { Alpha, beta } \\
\text { swipe analy- } \\
\text { sis }\end{array}$ & Mylar & vo & $P-10$ & $\begin{array}{l}0.09 \mathrm{nCi} \\
\text { for } 2.3- \\
\text { MeV beta }\end{array}$ & 578 & $\mathrm{NA}$ \\
\hline & $\begin{array}{l}\text { Gas flow pro } \\
\text { portional }\end{array}$ & $\begin{array}{l}\text { Tennelec } \\
\text { L8-5100 }\end{array}$ & $\begin{array}{l}\text { Swipe/air } \\
\text { filter analy- } \\
\text { sis }\end{array}$ & Mylar & $\sim 50$ & $P-10$ & $\begin{array}{l}0.02 \mathrm{nCl} \\
\text { for } 2.3- \\
\mathrm{MeV} \text { beta }\end{array}$ & 488 & NA \\
\hline & \multicolumn{9}{|l|}{ Facility 0} \\
\hline & $\begin{array}{l}\text { GM rate } \\
\text { meter }\end{array}$ & $\begin{array}{l}\text { Victoreen } 491 \\
\text { with } 491-30 \\
\text { probe }\end{array}$ & $\begin{array}{l}\text { Low-i evel } \\
\text { beta survey }\end{array}$ & Mica & 30 & Halogen & NR & NR & NA \\
\hline & $\begin{array}{l}\text { Rate meter } \\
\text { with pancake }\end{array}$ & $\begin{array}{l}\text { Victoreen } 490 \\
\text { with } 489-110 \\
\text { probe }\end{array}$ & $\begin{array}{l}\text { Low-1 eve } 1 \\
\text { beta detec- } \\
\text { tion }\end{array}$ & Mica & $\begin{array}{l}1.4 \text { to } \\
2.0\end{array}$ & Halogen & NR & NR & NA \\
\hline
\end{tabular}




\begin{tabular}{|c|c|c|c|c|c|c|c|c|}
\hline $\begin{array}{l}\text { Instrument } \\
\text { Type } \\
\end{array}$ & $\begin{array}{c}\text { Manuf acturer } \\
\text { and Number }\end{array}$ & Primary Use & $\begin{array}{c}\text { Beta } \\
\text { Window } \\
\text { Material } \\
\end{array}$ & $\begin{array}{l}\text { Window } \\
\text { Thj ckness } \\
\mathrm{mg} / \mathrm{cm}^{2} \\
\end{array}$ & $\begin{array}{l}\text { Oetector } \\
\text { Fill Gas }\end{array}$ & $\begin{array}{l}\text { Lower } \\
\text { Detection } \\
\text { Limit } \\
\end{array}$ & $\begin{array}{c}\text { Beta } \\
\text { Counting } \\
\text { Efficiency } \\
\end{array}$ & Al arm Set Point \\
\hline \multicolumn{9}{|l|}{$\frac{\text { Facility } 0}{(\text { conta) }}$} \\
\hline Survey meter & $\begin{array}{l}\text { Technical } \\
\text { Associates } \\
\text { Juno ERJ-9 }\end{array}$ & $\begin{array}{l}\text { Low- and } \\
\text { high-1 evel } \\
\text { beta survey }\end{array}$ & $\begin{array}{l}\text { Mylar } \\
\text { Cellulose- } \\
\text { Acetate }\end{array}$ & 0.5 & Air & NR & NR & NA \\
\hline Survey meter & $\begin{array}{l}\text { Technical } \\
\text { Associates }\end{array}$ & $\begin{array}{l}\text { Low- and } \\
\text { high-level }\end{array}$ & $\begin{array}{l}\text { Rubber } \\
\text { hydro- }\end{array}$ & 0.45 & $\mathrm{Ajr}$ & NR & NR & NA \\
\hline Survey meter & $\begin{array}{l}\text { Technical } \\
\text { Associates } \\
\text { Juno } 7\end{array}$ & Beta survey & $\begin{array}{l}\text { Rubber } \\
\text { hydro- } \\
\text { chloride }\end{array}$ & 0.45 & Air & NR & NR & NA \\
\hline $\begin{array}{l}\text { Laboratory } \\
\text { proportional } \\
\text { counter }\end{array}$ & $\begin{array}{l}\text { Nuclear Mea- } \\
\text { surement Co. } \\
\text { PCC } 11 T\end{array}$ & $\begin{array}{l}\text { Low-level } \\
\text { beta detec- } \\
\text { tion }\end{array}$ & NA & NR & NR & $10 \mathrm{dpm}$ & 408 & NA \\
\hline $\begin{array}{l}\text { Laboratory } \\
\text { proportional } \\
\text { counter }\end{array}$ & TGH Detector & $\begin{array}{l}\text { Low-energy } \\
\text { beta detec- } \\
\text { tion }\end{array}$ & Mica & 2.0 & Halogen & $40 \mathrm{dpm}$ & 208 & NA \\
\hline $\begin{array}{l}\text { Hdd hour } \\
\text { lab counter }\end{array}$ & $\begin{array}{l}111 \text { - LAKL } \\
460 \mathrm{CD}\end{array}$ & $\begin{array}{l}\text { veld UEceu- } \\
\text { tion }\end{array}$ & & & & & & \\
\hline $\begin{array}{l}\text { Gas flom } \\
\text { proportional } \\
\text { counter }\end{array}$ & Tennelec & $\begin{array}{l}\text { Low-level } \\
\text { beta detec- } \\
\text { tion }\end{array}$ & $\begin{array}{l}\text { Gold } \\
\text { coated } \\
\text { Mylar }\end{array}$ & 0.08 & $\begin{array}{l}\text { Argon/ } \\
\text { haTogen }\end{array}$ & $1 \mathrm{cpm}$ & $30 \%$ & NA \\
\hline \multicolumn{9}{|l|}{ Facility E } \\
\hline Ionization & Victoreen $470 \mathrm{~A}$ & $\begin{array}{l}\text { Dose rate } \\
\text { meter }\end{array}$ & Styrofoam & 17 & $\mathrm{Air}$ & $15 \mathrm{mrad} / \mathrm{h}$ & $\begin{array}{l}\text { Shlelded } \\
\pm 15 \% ; \\
8 \mathrm{keV}- \\
200 \mathrm{keV} \\
\text { Unshielded } \\
\pm 10 \% \\
40 \mathrm{keV}- \\
2 \mathrm{MeV}\end{array}$ & NA \\
\hline $\begin{array}{l}\mathrm{CM} \text { rate } \\
\text { meter }\end{array}$ & Victoreen 490 & $\begin{array}{l}\text { Beta-gamma } \\
\text { detector }\end{array}$ & Al umi num & 30 & $\begin{array}{l}\text { Organic } \\
\text { quench }\end{array}$ & $100 \mathrm{cpm}$ & Unknown & NA \\
\hline
\end{tabular}




\begin{tabular}{|c|c|c|c|c|c|c|c|c|}
\hline $\begin{array}{l}\text { Instrument } \\
\text { Type }\end{array}$ & $\begin{array}{l}\text { Manuf acturer } \\
\text { and Number }\end{array}$ & Primary Use & $\begin{array}{c}\text { Beta } \\
\text { Window } \\
\text { Material } \\
\end{array}$ & $\begin{array}{l}\text { Windom } \\
\text { Thickness } \\
\mathrm{mg} / \mathrm{cm}^{2} \\
\end{array}$ & $\begin{array}{l}\text { Oetector } \\
\text { Fill Cas }\end{array}$ & $\begin{array}{l}\text { Lomer } \\
\text { Detection } \\
\text { Limit } \\
\end{array}$ & $\begin{array}{c}\text { Beta } \\
\text { Counting } \\
\text { Efficiency } \\
\end{array}$ & Al arm Set \\
\hline \multicolumn{9}{|l|}{ Facility $\mathbf{F}$} \\
\hline $\begin{array}{l}\text { Rate meter } \\
\text { with pancake }\end{array}$ & $\begin{array}{l}\text { Ludl um Mode } \\
122-4 \text { LND } 7311 \\
\text { pancake }\end{array}$ & $\begin{array}{l}\text { Personnel } \\
\text { frisker }\end{array}$ & Mica & 2 & $\begin{array}{l}\text { Neon/ } \\
\text { hal ogen }\end{array}$ & $30 \mathrm{cpm}$ & NR & NA \\
\hline $\begin{array}{l}\text { Rotary switch } \\
\text { dose meter } \\
\text { with a tube } \\
\text { (end window) }\end{array}$ & $\begin{array}{l}\text { Elscant SCSK- } \\
1-21 \text { and GSM-1 }\end{array}$ & Survey meter & Mica & 2 & $\begin{array}{l}\text { Neon/ } \\
\text { halogen }\end{array}$ & $15 \mathrm{cpm}$ & NR & NA \\
\hline \multicolumn{9}{|l|}{ Facility $\mathrm{H}$} \\
\hline $\begin{array}{l}\text { Rate meters } \\
\text { with pancake } \\
\text { detectors }\end{array}$ & Eberline HP 260 & $\begin{array}{l}\text { Personnel } \\
\text { frisker }\end{array}$ & Micd & $\begin{array}{l}1.4 \text { to } \\
2.0\end{array}$ & $A i r$ & NR & $\begin{array}{l}108-{ }^{14} c \\
458-{ }^{2} \\
S r\end{array}$ & NA \\
\hline Ion chamber & Victoreen 440 & $\begin{array}{l}\text { Beta dose } \\
\text { rate }\end{array}$ & Myl ar & 3.0 & Air & NR & NR & NA \\
\hline $\begin{array}{l}\text { Ion chamber } \\
\text { condenser R- } \\
\text { meter }\end{array}$ & $\begin{array}{l}\text { Victoreen Model } \\
651 \text { and } 576\end{array}$ & $\begin{array}{l}\text { Beta dose } \\
\text { measurements }\end{array}$ & Myiar & $\begin{array}{l}6.6 \text { to } \\
7.0\end{array}$ & Air & NR & NR & MA \\
\hline \multicolumn{9}{|l|}{ Faci?ity 1} \\
\hline Ion chamber & Kanne & $\begin{array}{l}\text { Room and } \\
\text { stack monitor }\end{array}$ & NA & NA & Air & $2 \mu \mathrm{C}+/ \mathrm{m}^{3}$ & $60 \%$ to 804 & $36 \mu \mathrm{Ci} / \mathrm{m}^{3}$ \\
\hline Ion chamber & 0verhoff & $\begin{array}{l}\text { Room and } \\
\text { stack monitor }\end{array}$ & NA & NA & $\mathrm{Air}$ & $1 \mathrm{\mu Cf} / \mathrm{m}^{3}$ & 608 to 80 & $36 \mu \mathrm{Ci} / \mathrm{m}^{3}$ \\
\hline Ion chamber & Bendix & $T-446$ & NA & NA & Air & $10 \mu \mathrm{Ci} / \mathrm{m}^{3}$ & $60 \%$ to $80 \%$ & $50 \mu \mathrm{Ci} / \mathrm{m}^{3}$ \\
\hline $\begin{array}{l}\text { Gas propor- } \\
\text { tional }\end{array}$ & $\mathrm{NMC}, \mathrm{PC}-4,5$ & Lab counter & NA & NA & $P-10$ & $30 \mathrm{cpm}$ & $15 \%$ to 20 s & NA \\
\hline $\begin{array}{l}\text { Liquid scin- } \\
\text { tillation }\end{array}$ & $\begin{array}{l}\text { Packard } \\
\text { Mode1 } 460\end{array}$ & $\begin{array}{l}\text { Urinalysis } \\
\text { and stack } \\
\text { bubbler } \\
\text { counting }\end{array}$ & HA & NA & NA & $0.02 \mu \mathrm{Ci} / 1$ & $30 \%$ & NA \\
\hline
\end{tabular}




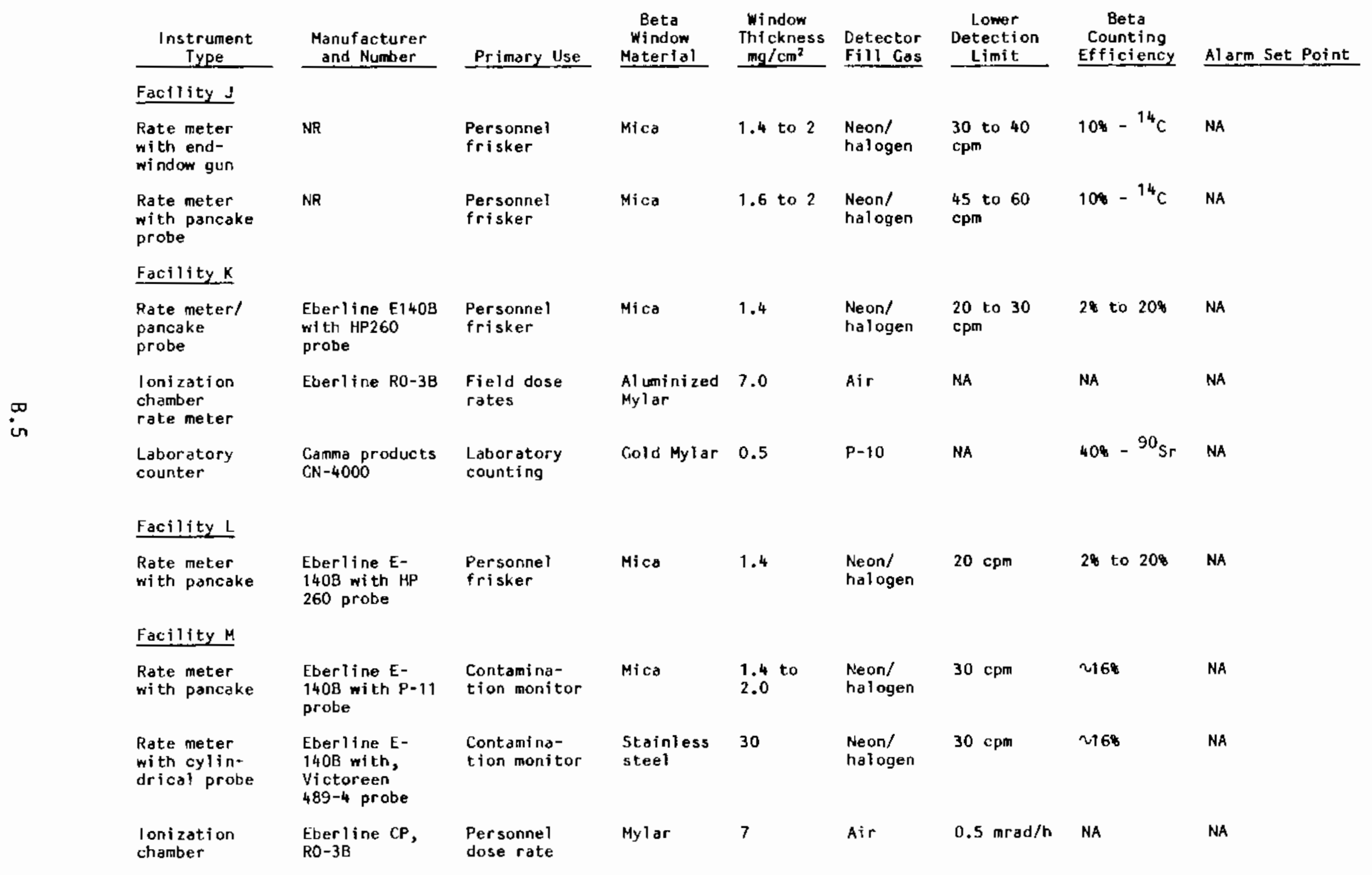




\begin{tabular}{|c|c|c|c|c|c|c|c|c|}
\hline $\begin{array}{l}\text { Instrument } \\
\text { Type } \\
\end{array}$ & $\begin{array}{l}\text { Manuf acturer } \\
\text { and Number }\end{array}$ & Primary Use & $\begin{array}{c}\text { Beta } \\
\text { Windom } \\
\text { Material } \\
\end{array}$ & $\begin{array}{l}\text { window } \\
\text { Thickness } \\
\text { mg/cm } \\
\end{array}$ & $\begin{array}{l}\text { Detector } \\
\text { Fill Gas }\end{array}$ & $\begin{array}{c}\text { Lower } \\
\text { Detection } \\
\text { Limft } \\
\end{array}$ & $\begin{array}{c}\text { Beta } \\
\text { Counting } \\
\text { Efficiency }\end{array}$ & Al arm Set Point \\
\hline \multicolumn{9}{|l|}{$\frac{\text { Facility } M}{(\operatorname{cont} d)}$} \\
\hline $\begin{array}{l}\text { Hand \& shoe } \\
\text { counter }\end{array}$ & $\begin{array}{l}\text { Eberline, } \\
\text { HFM-4 }\end{array}$ & $\begin{array}{l}\text { Personnel } \\
\text { contamination }\end{array}$ & Mylar & $\begin{array}{l}1.4 \text { to } \\
2.0\end{array}$ & $P-10$ & $30 \mathrm{cpm}$ & $\sim 20 \%$ & NR \\
\hline $\begin{array}{l}\text { Scaler/timer } \\
\text { with beta } \\
\text { probe }\end{array}$ & $\begin{array}{l}\text { Eberline MS-3 } \\
\text { scaler, RD-13 } \\
\text { or } \mathrm{HP}-210 \mathrm{GM} \\
\text { probe }\end{array}$ & $\begin{array}{l}\text { Air sample } \\
\text { and smear } \\
\text { count }\end{array}$ & Mica/Mylor & $\begin{array}{l}1.4 \text { to } \\
2.0\end{array}$ & $\begin{array}{l}\text { Neon/ } \\
\text { halogen }\end{array}$ & $30 \mathrm{cpm}$ & 208 & NA \\
\hline \multicolumn{9}{|l|}{ Facility $\mathrm{N}$} \\
\hline $\begin{array}{l}\text { Rate meter } \\
\text { with pancake }\end{array}$ & $\begin{array}{l}\text { Eberline E- } \\
1401 \text { with } \\
\text { HP } 260 \text { probe }\end{array}$ & $\begin{array}{l}\text { Personnel } \\
\text { frisker }\end{array}$ & Mica & 1.4 & $\begin{array}{l}\text { Neon/ } \\
\text { halogen }\end{array}$ & $\begin{array}{l}20 \text { to } 30 \\
\mathrm{cpm}\end{array}$ & 28 to 208 & NA \\
\hline \multicolumn{9}{|l|}{ Facility 0} \\
\hline Rate meter & $\begin{array}{l}\text { Eberline and } \\
\text { Ludlum P-210 } \\
\text { probe }\end{array}$ & $\begin{array}{l}\text { Per sonnel } \\
\text { survey }\end{array}$ & Mica & 1.4 to 2 & Air & Unknown & 108 & $\begin{array}{l}500 \mathrm{c} / m \text { above } \\
\text { background }\end{array}$ \\
\hline \multirow[t]{3}{*}{ Ion chamber } & Ro2A & Exposure rate & Mylar & 0.5 & Air & $1 \mathrm{mR} / \mathrm{h}$ & Unknown & NA \\
\hline & Juno & Exposure rate & Mylar & 0.5 & Air & $1 \mathrm{mR} / \mathrm{h}$ & Unknown & NA \\
\hline & Cutie pie & Exposure rate & Mylar & 0.5 & Air & $1 \mathrm{mR} / \mathrm{h}$ & Unknown & NA \\
\hline \multicolumn{9}{|l|}{ Facility $P$} \\
\hline $\begin{array}{l}\text { Rate meter } \\
\text { with pancake }\end{array}$ & $\begin{array}{l}\mathrm{RH}-14 \text { or } \\
\mathrm{P}-210\end{array}$ & $\begin{array}{l}\text { Personnel and } \\
\text { equipment } \\
\text { survey }\end{array}$ & $\begin{array}{l}\text { Mylar or } \\
\text { Mica }\end{array}$ & 5 to 10 & Ai r & $20-200 \mathrm{cpm}$ & 108 to 408 & NA \\
\hline $\begin{array}{l}\text { Large area } \\
\text { proportional } \\
\text { detector }\end{array}$ & $\begin{array}{l}\text { In-house } \\
\text { design }\end{array}$ & $\begin{array}{l}\text { Personnel } \\
\text { survey }\end{array}$ & Mylar & 5 to 6 & $\begin{array}{l}\text { Airl } \\
\text { halogen }\end{array}$ & $\begin{array}{l}100 \mathrm{cpm} / \\
100 \mathrm{~cm}^{2}\end{array}$ & 308 & $2 \sigma$ \\
\hline
\end{tabular}

\section{Facility 0}

No response 


\begin{tabular}{|c|c|c|c|c|c|c|c|c|}
\hline $\begin{array}{c}\text { Instrument } \\
\text { Type }\end{array}$ & $\begin{array}{l}\text { Manuf acturer } \\
\text { and Number }\end{array}$ & Primary Use & $\begin{array}{c}\text { Beta } \\
\text { Window } \\
\text { Material }\end{array}$ & $\begin{array}{l}\text { Window } \\
\text { Thickness } \\
\text { mg } / \mathrm{cm}^{2} \\
\end{array}$ & $\begin{array}{l}\text { Detector } \\
\text { Fijl Gas }\end{array}$ & $\begin{array}{c}\text { Lower } \\
\text { Detection } \\
\text { Limit } \\
\end{array}$ & $\begin{array}{c}\text { Beta } \\
\text { Counting } \\
\text { Efficiency }\end{array}$ & Alarm Set Point \\
\hline \multicolumn{9}{|l|}{ Facility $R$} \\
\hline $\begin{array}{l}\text { Rate meter } \\
\text { with pancake }\end{array}$ & Ludl um 12 & $\begin{array}{l}\text { Personnel } \\
\text { frisker }\end{array}$ & Mica & 1.5 to 2 & $\begin{array}{l}\text { Neon/ } \\
\text { halogen }\end{array}$ & NR & NR & NA \\
\hline $\begin{array}{l}\text { Rate meter } \\
\text { with pancake }\end{array}$ & $\begin{array}{l}\text { Eberline E- } \\
120 \text { with HP- } \\
210 \text { probe }\end{array}$ & $\begin{array}{l}\text { Personnel } \\
\text { frisker }\end{array}$ & Mica & 1.5 to 2 & $\begin{array}{l}\text { Neon/ } \\
\text { halogen }\end{array}$ & NR & NR & NA \\
\hline $\begin{array}{l}\text { Rate meter } \\
\text { wi th end } \\
\text { window }\end{array}$ & $\begin{array}{l}\text { Victoreen } 425 \\
\text { with TGM } 210 \\
\text { probe }\end{array}$ & $\begin{array}{l}\text { Personnel } \\
\text { frisker }\end{array}$ & Mica & 1.5 to 2 & $\begin{array}{l}\text { Neon/ } \\
\text { halogen }\end{array}$ & NR & NR & NA \\
\hline Ion chamber & Victoreen 471 & Survey meter & Mylar & 1.1 & Air & NR & NR & NA \\
\hline $\begin{array}{l}\text { Proportinal } \\
\text { gas flow } \\
\text { counter }\end{array}$ & Eberline FC-2 & Smear counting & NA & NR & $P-10$ & NR & NR & NA \\
\hline $\begin{array}{l}\text { Proportional } \\
\text { gas flow } \\
\text { counter }\end{array}$ & $\begin{array}{l}\text { Tennelec } \\
\text { LB5100 }\end{array}$ & $\begin{array}{l}\text { Gross alpha/ } \\
\text { beta }\end{array}$ & NA & $N R$ & $P-10$ & NR & NR & NA \\
\hline Ion chamber & Johnston $1055 \mathrm{~b}$ & ${ }^{3} \mathrm{H}$ monitor & $\mathrm{NA}$ & NR & Air & NR & NR & NA \\
\hline $\begin{array}{l}\text { Liquid } \\
\text { scintillator }\end{array}$ & Beckman L58100 & ${ }^{3} \mathrm{H}$ monitor & NA & NR & Air & NR & NR & NA \\
\hline \multicolumn{9}{|l|}{ Facilitys } \\
\hline Eberline E-530 & HP260 & $\begin{array}{l}\text { Personnel } \\
\text { frisker }\end{array}$ & Mica & $\begin{array}{l}1.4 \\
2.0\end{array}$ & Air & $20 \mathrm{cpm}$ & 208 to 50 \% & NA \\
\hline $\begin{array}{l}\text { Gas flow pro- } \\
\text { portional and } \\
\text { scaler }\end{array}$ & $\begin{array}{l}\text { Ludl um Model } \\
2500 \text { with } \\
\text { NMC chamber }\end{array}$ & Lab counter & Mylar & Unknown & $P-10$ & $20 \mathrm{cpm}$ & 208 to 508 & NA \\
\hline Air monitor & Eberline AMS-3 & $\begin{array}{l}\text { Air monitor- } \\
\text { ing }\end{array}$ & Mica & $\begin{array}{l}1.4 \text { to } \\
2.0\end{array}$ & Air & $\checkmark 500 \mathrm{cpm}$ & 308 to 408 & $\begin{array}{l}1000 \mathrm{cpm} \\
\text { >background }\end{array}$ \\
\hline
\end{tabular}




\begin{tabular}{|c|c|c|c|c|c|c|c|c|}
\hline $\begin{array}{c}\text { Instrumerit } \\
\text { Iype } \\
\end{array}$ & $\begin{array}{c}\text { Manuf acturer } \\
\text { and Number }\end{array}$ & Primary Use & $\begin{array}{c}\text { Beta } \\
\text { Window } \\
\text { Material }\end{array}$ & $\begin{array}{l}\text { Window } \\
\text { Thickness } \\
\mathrm{mg} / \mathrm{cm}^{2} \\
\end{array}$ & $\begin{array}{l}\text { Detector } \\
\text { Fill Gas }\end{array}$ & $\begin{array}{c}\text { Lower } \\
\text { Detection } \\
\text { Limit } \\
\end{array}$ & $\begin{array}{c}\text { Beta } \\
\text { Counting } \\
\text { Efficiency } \\
\end{array}$ & Alarm Set Paint \\
\hline \multicolumn{9}{|l|}{ Facjlity $T$} \\
\hline $\begin{array}{l}\text { Beta hand and } \\
\text { foot counter }\end{array}$ & $\begin{array}{l}\text { In-house } \\
\text { design }\end{array}$ & $\begin{array}{l}\text { Personnel } \\
\text { frisker }\end{array}$ & $\begin{array}{l}\text { Stainless } \\
\text { steel }\end{array}$ & Unknown & Unknown & Unknown & Unknown & Unknown \\
\hline $\begin{array}{l}\text { Rate meter } \\
\text { with pancake }\end{array}$ & $\begin{array}{l}\text { Ludl um Model } \\
31 \text { with 44-9 } \\
\text { probe }\end{array}$ & Area survey & Mica & $n_{2}$ & Aír & Unknown & $70 \%$ & NA \\
\hline \multicolumn{9}{|l|}{ Facijjty U } \\
\hline $\begin{array}{l}\text { Rate meter } \\
\text { with pancake }\end{array}$ & $\begin{array}{l}\text { Technical } \\
\text { Associates } \\
\text { TBM-3 }\end{array}$ & $\begin{array}{l}\text { Portable } \\
\text { Survey }\end{array}$ & Hica & 1.5 & $\begin{array}{l}\text { Helium/ } \\
\text { halogen }\end{array}$ & $20 \mathrm{cpm}$ & Unknown & NA \\
\hline $\begin{array}{l}\text { Rate meter } \\
\text { with ion } \\
\text { chamber }\end{array}$ & Eberiine R0-3 & $\begin{array}{l}\text { Portable } \\
\text { Survey }\end{array}$ & Mylar & 1.7 & Air & $0.2 \mathrm{mR} / \mathrm{h}$ & Unknown & NA \\
\hline $\begin{array}{l}\text { Various rate } \\
\text { meters with } \\
\text { HP270 GM } \\
\text { probe }\end{array}$ & $\begin{array}{l}\text { Eberline E500, } \\
\text { E510, ES20, } \\
\text { E530, R4-3, 14, } \\
15,19 \text {, and } 20\end{array}$ & $\begin{array}{l}\text { Portable } \\
\text { Survey }\end{array}$ & $\begin{array}{l}\text { Stainless } \\
\text { steel }\end{array}$ & 30 & $\begin{array}{l}\text { Argon/ } \\
\text { halogen }\end{array}$ & $\begin{array}{l}0.01 \text { to } \\
1 \mathrm{mR} / \mathrm{h} \text { or } \\
10 \mathrm{cpm}\end{array}$ & Unknown & NA \\
\hline Air monitor & $\begin{array}{l}\text { Eber } 1 \text { ine } \\
\text { AMS }-3\end{array}$ & Air monitor & Mica & 5 to 6 & $\begin{array}{l}\text { Helium/ } \\
\text { halogen }\end{array}$ & $10 \mathrm{cpm}$ & linknown & Variable \\
\hline $\begin{array}{l}\text { Rate meter } \\
\text { with pancake }\end{array}$ & $\begin{array}{l}\text { Technical } \\
\text { Associates } \\
\text { WT-1-B1 }\end{array}$ & $\begin{array}{l}\text { Hand and foot } \\
\text { monitor }\end{array}$ & Mica & 1.5 & $\begin{array}{l}\text { Helium/ } \\
\text { halogen }\end{array}$ & $2 \mathrm{cpm}$ & linknown & $500 \mathrm{cpm}$ \\
\hline $\begin{array}{l}\text { Tennelec with } \\
\text { scintillation } \\
\text { probe }\end{array}$ & $\begin{array}{l}\text { Various NIM } \\
\text { modules with } \\
\text { Shephard DP-2 } \\
\text { probe }\end{array}$ & $\begin{array}{l}\text { Swipe analy- } \\
\text { sis }\end{array}$ & Mylar & 1.1 & NR & $5 \mathrm{cpm}$ & 308 & NA \\
\hline $\begin{array}{l}\text { Dose meter } \\
\text { with ion } \\
\text { chamber }\end{array}$ & Overhoff 786 & $\begin{array}{l}\text { Radioactive } \\
\text { gas monitor }\end{array}$ & NR & NR & Air & $1 \mu \mathrm{Ci} / \mathrm{m}^{3}$ & NR & $1 \mu \mathrm{Ci} / \mathrm{m}^{3}$ \\
\hline \multicolumn{9}{|l|}{ Facility $V$} \\
\hline $\begin{array}{l}\text { Rate meter } \\
\text { (thin wall) }\end{array}$ & $\begin{array}{l}\text { Victoreen } \\
\text { CDV-700 }\end{array}$ & $\begin{array}{l}\text { Ceneral } \\
\text { detection }\end{array}$ & $\begin{array}{l}\text { Stainless } \\
\text { steel }\end{array}$ & 30 & $\begin{array}{l}\text { Air/ } \\
\text { halogen }\end{array}$ & $50 \mathrm{cpm}$ & NR & NA \\
\hline
\end{tabular}




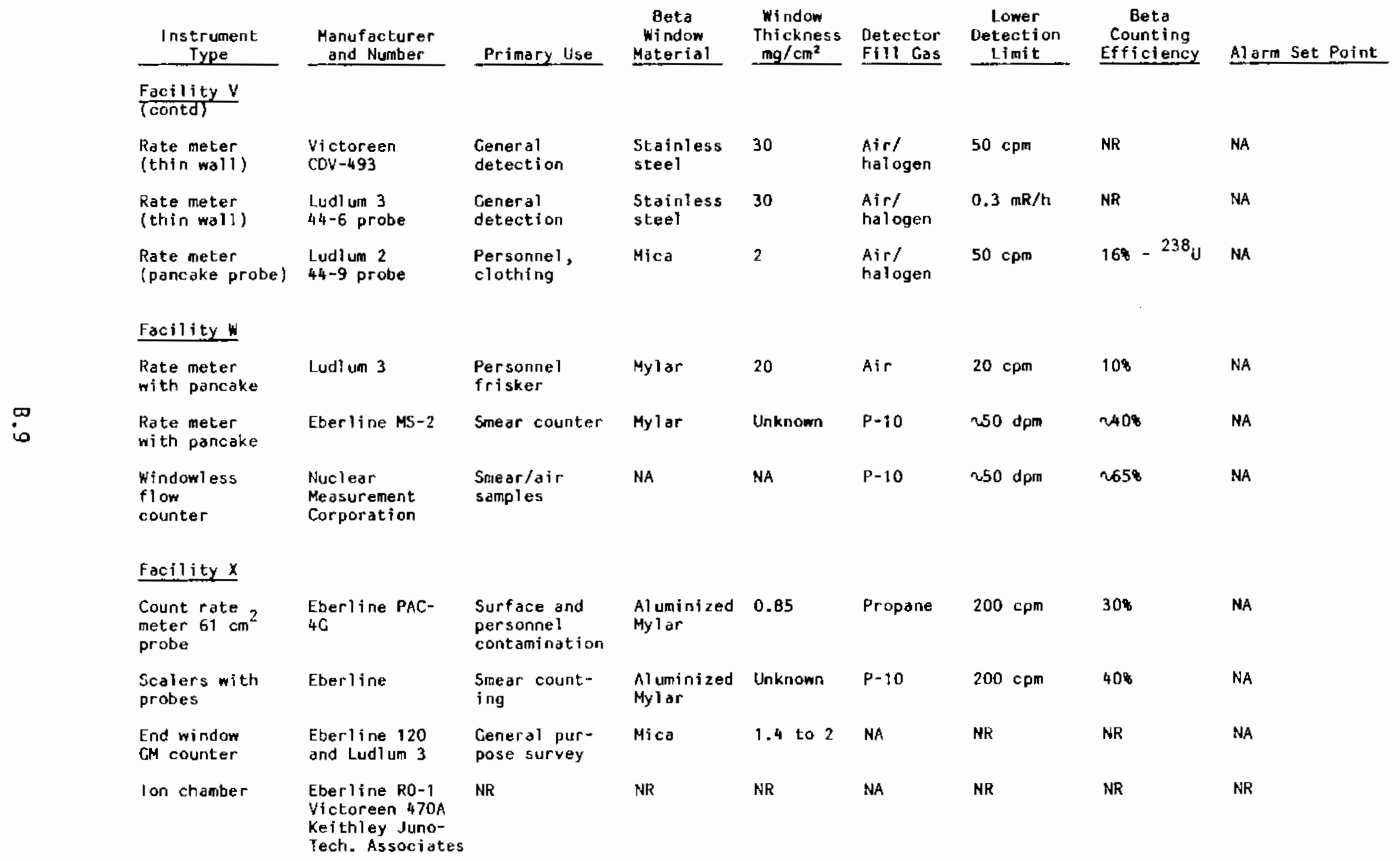




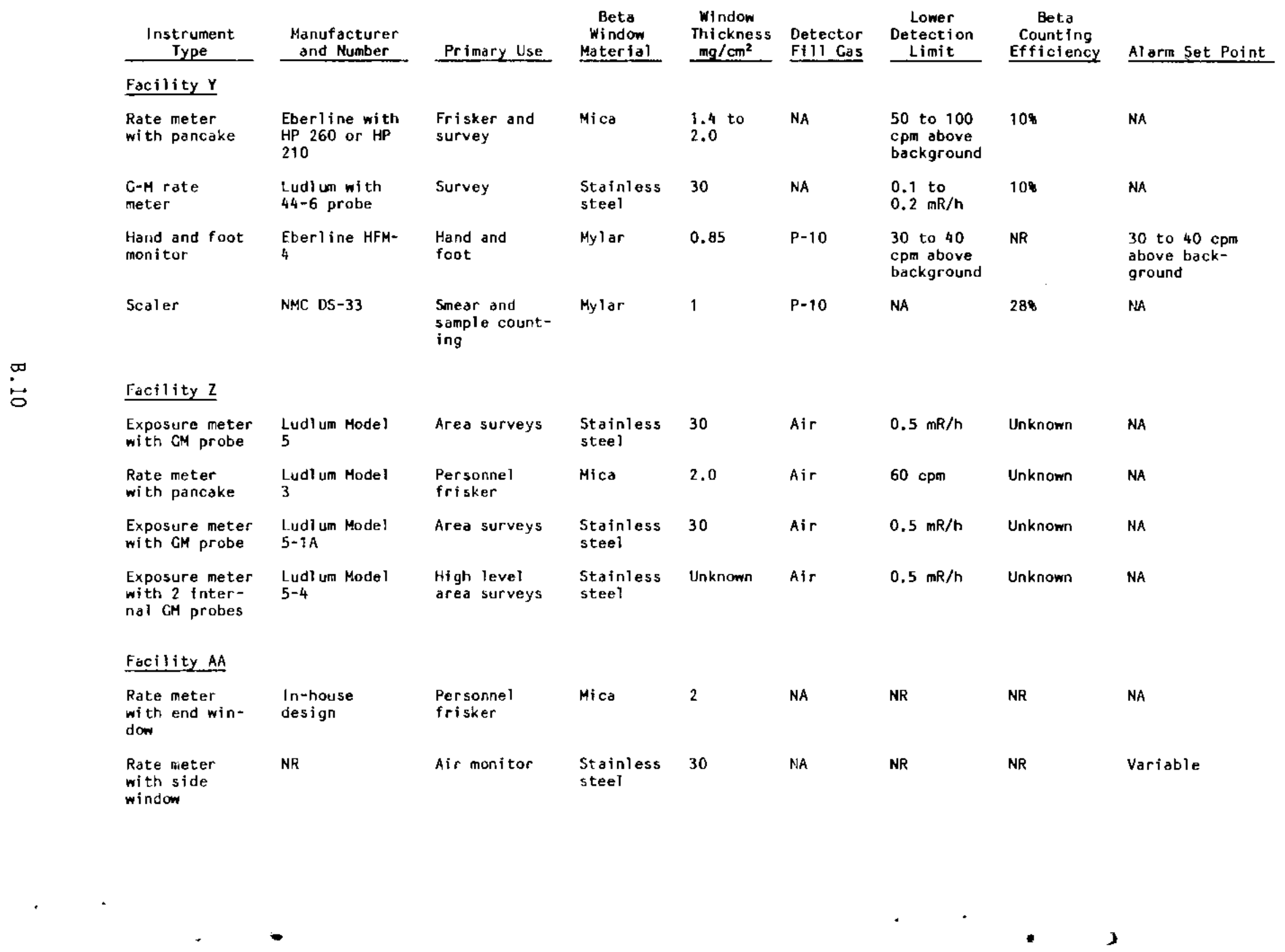




\begin{tabular}{|c|c|c|c|c|c|c|c|c|}
\hline $\begin{array}{c}\begin{array}{c}\text { Instrument } \\
\text { Iype }\end{array} \\
\end{array}$ & $\begin{array}{l}\text { Manuf acturer } \\
\text { and Number }\end{array}$ & Primary Use & $\begin{array}{c}\text { Beta } \\
\text { Window } \\
\text { Material } \\
\end{array}$ & $\begin{array}{l}\text { Window } \\
\mathrm{rhickness} \\
\mathrm{mg} / \mathrm{cm}^{2} \\
\end{array}$ & $\begin{array}{l}\text { Detector } \\
\text { Fill Gas }\end{array}$ & $\begin{array}{c}\text { Lower } \\
\text { Detection } \\
\text { Limit } \\
\end{array}$ & $\begin{array}{c}\text { Beta } \\
\text { Counting } \\
\text { Efficiency } \\
\end{array}$ & Alarm Set Point \\
\hline \multicolumn{9}{|l|}{ Facility $8 B$} \\
\hline $\begin{array}{l}\text { Rate meter } \\
\text { with pancake }\end{array}$ & $\begin{array}{l}\text { Eberline Mode! } \\
140 \text { with HP- } \\
260\end{array}$ & $\begin{array}{l}\text { Surface con- } \\
\text { tamination }\end{array}$ & $M i c a$ & 7 & $\begin{array}{l}\text { Neon/ } \\
\text { halogen }\end{array}$ & $240 \mathrm{cpm}$ & $900_{\mathrm{Sr}}^{(4 \pi)}$ & NA \\
\hline $\begin{array}{l}\text { Rate meter } \\
\text { with pancake }\end{array}$ & $\begin{array}{l}\text { Ludl um Model } \\
101 \text { with 44-9 }\end{array}$ & $\begin{array}{l}\text { Surface con- } \\
\text { tamination }\end{array}$ & Mica & 7 & $\begin{array}{l}\text { Neon/ } \\
\text { halogen }\end{array}$ & $240 \mathrm{cpm}$ & $90^{20}(4 \pi)$ & NA \\
\hline Scaler & $\begin{array}{l}\text { EIC Model MS-2 } \\
\text { and MS-3 }\end{array}$ & $\begin{array}{l}\text { Swipe count- } \\
\text { ing }\end{array}$ & Mylar & 0.85 & Propane & $30 \mathrm{cpm}$ & 508 & $\mathrm{NA}$ \\
\hline Scaler & $\begin{array}{l}\text { Tennelec } \\
\text { LB5100 series }\end{array}$ & $\begin{array}{l}\text { Swipe count- } \\
\text { ing }\end{array}$ & $\begin{array}{l}\text { Cold } \\
\text { coated } \\
\text { poly car- } \\
\text { bonate }\end{array}$ & 80 & $P-10$ & $6 \mathrm{cpm}$ & 2388 & NA \\
\hline $\begin{array}{l}\text { Tritium moni- } \\
\text { tor }\end{array}$ & $\begin{array}{l}\text { Johnston Model } \\
111\end{array}$ & $\begin{array}{l}\text { Air monitor- } \\
\text { ing }\end{array}$ & NR & $\mathrm{NA}$ & Air & $1 \mu \mathrm{Ci} / \mathrm{m}^{3}$ & Variable & Variable \\
\hline \multicolumn{9}{|l|}{ Facility $C C$} \\
\hline Proportional & Tennelec 5100 & $\begin{array}{l}\text { Swipe count- } \\
\text { ing }\end{array}$ & Gold & 0.5 & $P-10$ & $1 \mathrm{cpm}$ & 428 & NA \\
\hline Proportional & $\mathrm{PC}-4 / 5$ & $\begin{array}{l}\text { Swipe count- } \\
\text { ing }\end{array}$ & Mylar & 7 & $P-10$ & $20 \mathrm{cpm}$ & 448 & $\mathrm{NA}$ \\
\hline
\end{tabular}




\section{*}


PNL -5960

UC-4 I

\section{DISTRIBUTION}

No. of

Copies

OFFSITE

30 Technical Information Center

DOE Headquarters

R. W. Barber, Director

Nuclear Reactor and Facility

Safety Division

U.S. Department of Energy

Washington, D.C. 20545

L. J. Deal, Acting Director

Division of Radiological Controls

U.S. Department of Energy

Washington, D.C. 20545

N. Goldenberg, Acting Director

Quality Assurance

U.S. Department of Energy

Washington, D.C. 20545

B. L. Murphy

Health Physics

U.S. Department of Energy

Wastington, D.C. 20545

G. K. Oerte I, Deputy Asst.

Secretary for Safety, Health, and Quality Assurance

U.S. Department of Energy

Washington, D.C. 20545

R. J. Stern, Director

Office of Environmental Guidance

U.S. Department of Energy

Washington, D.C. 20545

2.5 E. J. Vallario

Acting Director

Radiological Controls Division

Office of Nuclear Safety

U.S. Department of Energy

Washington, D.C. 20545

M. Walker

Assistant Secretary for

Environment, Safety and Health

U.S. Department of Energy

Washington, D.C. 20545
No. of

Copies

DOE Albuquerque Operations Office

R. E. Alexander, Safety Director Pantex Plant

Mason \& Hanger--Silas Mason Co., Inc.

P.0. Box 30020

Amari110, TX 79177

W. D. Burnett, Manager

Health Physics Division

DOE Sandia National Laboratories

Mail Code 3312, Bidg. 8619

P.0. Box 2800

Albuquerque, NM 87115

G. W. Campbe 11

Rockwell International Corp.

Rocky Flats, P.0. Box 454

Golden, C0 B0401

C. E. Garcia

U.S. Department of Energy

Albuquerque Operations Office

P.0. Box 5400

Albuquerque, NM 87115

H. E. Meyer, Manager

Health Physics

Mound Laboratory

Monsanto Research Corporation

P.0. Box 32

Miamisburg, $\mathrm{OH} 45342$

P. M. Ramey

ATbuquerque Operations Office

U.S. Department of Energy

P.0. Box 5400

Atbuquerque, NM 87115

J. J. Thompson

Lovelace Biomedical \& Environmental

Research Laboratories

Health Protection 0perations

P.0. Box 5890

Albuquerque, NM 87115 
No. of

Copies

A. M. Valentine, Group Leader Health Physics

Los Alamos National Laboratory P.0. Box 1663

Los Alamos, NM 87545

M. G. White

U.S. Department of Energy

P.0. Box 5400

Albuquerque, NM 87115

R. E. Yoder, Director

Health, Safety, and Environment

Rockwell Internationa 1

P.0. Box 888

Golden, CO 80401

DOE Chicago Operations Office

D. L. Bray

U.S. Department of Energy

9800 S. Cass Ave.

Argonne, IL 60439

L. V. Coulson, Head

Safety Section

Fermi National Accelerator Laboratory

P.0. Box 500

Batavia, IL 60510

E. H. Dolecek

Argonne National Laboratory

9800 S. Cass Ave., B1dg. 201

Argonne, IL 60439

C. B. Meinhold, Head

Safety \& Environmental Protection

Division

Brookhaven National Laboratory

Associated Universities, Inc.

Upton, NY 11973

R. Moser, Director

Operational \& Environmental

Safety Division

Chicago Operations Office

U.S. Department of Energy

9800 S. Cass Avenue

Argonne, IL 60439
No. of

Copies

D. P. O'Neil

Argonne National Laboratory

$9800 \mathrm{~S}$. Cass Ave.

Argonne, IL 60439

DDE Idaho Operations Office

J. H. Barry, Director

Operational Safety Division

Idaho Operations Office

U.S. Department of Energy

550 2nd Street

Idaho Falls, ID 83401

B. J. Beers, Assistant Manager

Environmenta1, Safety and

Health Programs

Idaho Operations office

U.S. Department of Energy

550 2nd Street

Idaho Falls, ID 83401

T. F. Gesel?

Radiological and Environmental

Sciences Laboratory

U.S. Department of Energy

550 2nd stroet

Idaho Falls, ID 83401

B. L. Rich

Health and Safety Division

EG\&G I daho

P.0. Box 1625

Idaho Falls, ID 83401

DOE Naval Reactors Office

T. L. Collins, Manager

Knolis Atomic Power Laboratory

U.S. Department of Energy

P.0. Box 1072

Schenectady, NY 12301

A. C. Davis, Manager

Bettis Atomic Power Lab.

Westinghouse Electric Corporation

P.0. Box 79

West Mifflin, PA 15122 
No. of

Copies

C. K. Gaddis, Manager

Pittsburgh Naval Reactors Office

P.0. Box 109

West Mifflin, PA 15122

DOE Nevada Operations Office

B. W. Church

Health Physics Division

Nevada Operations Office

U.S. Department of Energy

P.O. Box 14100

Las Vegas, NV 89114

S. R. Elliot, Director

Office of Safety and Health

Nevada Operations Office

U.S. Department of Energy

P.0. Box 14100

Las Vegas, NV 89114

\section{A. Bicker \\ Environmental Sciences \\ Department Manager \\ Nevada Test Site \\ Mercury, NV 89033 \\ DOE 0ak Ridge 0perations Office}

R. C. Baker

Head \& Envirommental Coordinator

Environmental Control Department

Paducah Gaseous Diffusion Plant

P.0. Box 1410

Paducah, KY 42001

W. F. Furth, Director

Environmental Safety and Health

Martin Marietta Energy Systems

P.0. Box X

Oak Ridge, TN 37831

R. E. Halliburton

Oak Ridge National Laboratory

P.0. Box $X$

Oak Ridge, TN 37830
No. of

Copies

S. L. Hinnefeld

Radiation Safety Department

Westinghouse Materials Co. of Ohio

P.0. Box 398704

Cincinnati, $\mathrm{OH} \quad 45239$

D. B. Howard

Oak Ridge Operations Office

U.S. Department of Energy

P.0. Box E

Oak Ridge, TN 37831

T. M. Jelinek, Chief

Health Protection Branch

Oak Ridge Operations Office

U.S. Department of Energy

P.O. Box E

Oak Ridge, TN 37831

W. T. Mee, Superintendent

Radiation Safety Department

$Y-12$

P.0. Box Y

Oak Ridge, TN 37830

D. C. Parzyck, Director

EnvironmentaT and Occupational

Safety Division

Oak Ridge National Laboratory

P. 0. Box $X$

Oak Ridge, TN 37830

B. G. Roach

Health and Safety Officer

ORAU

P.0. Box 117

Oak Ridge, TN 37831

J. Shoemaker

Heaith Physics \& Environmentai

Affairs Division

Oak Ridge Gaseous Diffusion Plant

P.O. Box $P$

Oak Ridge, TN 37831 
PNL -5960

UC -41

No. of

Copies

F. G. VanLoocke

Health, Safety and Security

Representative

RMI

P.0. Box 579

Ashtabula, OH 44004

E. Wagner

Industrial Hygiene and

Health Physics Dept.

GAT

P.0. Box 628

Piketon, $\mathrm{OH} 45661$

DOE San Francisco Operations

office

T. R. Crites

Lawrence Livermore Nationa?

Laboratory

P.0. Box 5505

Livermore, CA 94550

J. T. Davis, Chief

Operational Safety and Compliance

San Francisco Operations Office

U.S. Department of Energy

1333 Broadway

Oakland, CA 94612

R. V. Griffith

Lawrence Livermore National

Laboratory

P.D. Box 5505

Livermore, CA 94550

W. E. Keheley, Branch Chief

Environment and Nuclear Safety

San Francisco Operations Office

U.S. Department of Energy

1333 Broadway

0akland, CA 94612

R. C. McCa 11, Rad. Safety Officer

Stanford Linear Accelerator

P.0. Box 4349

Stanford, CA 94305
No. of

Copies

P. Phelps

Lawrence Livermore Laboratory

P.0. Box 5505

Livermore, CA 94550

R. H. Thomas

Lawrence Berkeley Nationa?

Laboratory

University of California

Berkeley, CA 94720

A. J. Toy, Head

Hazard Control Department

Lawrence Livermore National

Laboratory

P.0. Box 808

Livermore, CA 94550

DOE Savannah River Operations

office

D. N. Bridges

Savannah River Operations Office

U.S. Department of Energy

P.0. Box A

Aiken, SC 29801

R. M. Ha 11

E.I. Du Pont de Nemours \& Co. Savannah River Plant

Aiken, SC 29809

W. A. Reese, Director

Safety and Environmenta] Division

Savannah River Operations Office

U.S. Department of Energy

P.0. Box A

Aiken, SC 29801

W. C. Reinig, Superintendent

Health Protection Department

E. I. Du Pont de Nemours \& Co.

Savannah River Plant

Aiken, SC 29809 
No. of

Copies

EPA Office of Radiation Programs

A. Richardson

Criteria \& Standards Division

AW-460

401 M Street, SW

Wastington, DC 20460

National Center for Devices and

Radiological Health

J. T. Lewis

Center for Dev. \& Radiol. Health

Office of Health Physics

HFZ-60, Rm. Chap. 332

5600 Fishers Lane

Rockville, MD 20857

J. C. Villforth, Director

FDA Bureau of Radiological Health

Rockville, MD 20852

National Bureau of Standards

R. Colle'

National Bureau of Standards

Gaithersburg, MD 20899

E. H. Eisenhower

Office of Radiation Measurement

National Bureau of Standards

Gaithersburg, MD 20899

$R$. Loevinger

National Bureau of Standards

Gaithersburg, MD 20899

R. B. Schwartz

National Bureau of Standards

Building 235

Gaithersburg, MD 20899

Nuclear Regulatory Commission

R. E. Alexander, Chief

Radiation Risk Assessments and

Managenent Branch

Office of Nuclear Regulatory

Research

U.S. Nuclear Regulatory Commission

Washington, DC 20555
No. of

Copies

A. Brodsky

U.S. Nuclear Regulatory Commission

Wilste Bldg., MS-1130 SS

7515 Eastern Ave.

SiTver Spring, MD 20912

L. K. Cohen

Office of Inspection \& Enforcement

U.S. Nuclear Regulatory Commission Washington, DC 20555

L. J. Cunningham

Operating Reactor Programs Branch

Division of Inspection Programs

U.S. Nuclear Regulatory Comission

Wastington, DC 20555

M. V. Federline

Office of Executive Director for Operation

U.S. Nuclear Regulatory Commission Washington, DC 20555

K. R. Goller

U.S. Nuclear Regulatory Cominission

Div. of Rad. Prog. \& Earth

Sciences, MS-1130 55

Washington, DC 20555

R. E. Minogue, Director

Office of Nuclear Regulatory

Research

U.S. Nuclear Regulatory Commission Washington, DC 20555

R. B. Nee?

U.S. Nuclear Regulatory Commission

Wilste BIdg., MS-1130 SS

7515 Eastern Ave.

Silver Spring, MD 20912

L. C. Rouse, Chief

Advanced Fuel and Spent Fue?

Licensing Branch

Division of Fuel Cycle \& Materia? Safety

U.S. Nuclear Regulatory Commission Washington, DC 20555 
No. of

Copies

ONSITE

3 DOE Richland Operations of fice

J. J. Sutey/P. K. Clark

R. E. Gerton

K. H. Rising

Rockwell

J. F. Albaugh

Westinghouse

R. 0. Budd

United Nuclear Industries

W. L. Nees

52 Pacific Northwest Laboratory

W. J. Bair

L. W. Brakenbush (25)

G. W. R. Endres

T. H. Essig

L. G. Faust

J. J. Fix

D. E. Hadlock

R. Harty

G. R. Hoenes

R. L. Kathren

H. V. Larson

L. A. Rathbun

W. 0. Reece

J. M. Selby (5)

K. L. Swinth

R. J. Traub

Publishing Coordination (2)

Technical Report Files (5)

Health Physics Dept. Library 